\title{
A CBCT evaluation of root position within bone, long axis inclination, and the WALA Ridge
}

Timothy R. Glass

Follow this and additional works at: https://researchrepository.wvu.edu/etd

\section{Recommended Citation}

Glass, Timothy R., "A CBCT evaluation of root position within bone, long axis inclination, and the WALA Ridge" (2016). Graduate Theses, Dissertations, and Problem Reports. 5678.

https://researchrepository.wvu.edu/etd/5678

This Thesis is protected by copyright and/or related rights. It has been brought to you by the The Research Repository @ WVU with permission from the rights-holder(s). You are free to use this Thesis in any way that is permitted by the copyright and related rights legislation that applies to your use. For other uses you must obtain permission from the rights-holder(s) directly, unless additional rights are indicated by a Creative Commons license in the record and/ or on the work itself. This Thesis has been accepted for inclusion in WVU Graduate Theses, Dissertations, and Problem Reports collection by an authorized administrator of The Research Repository @ WVU. For more information, please contact researchrepository@mail.wvu.edu. 


\title{
A CBCT EVALUATION OF ROOT POSITION WITHIN BONE, LONG AXIS INCLINATION, AND THE WALA RIDGE
}

\author{
Timothy R. Glass D.D.S. \\ A THESIS submitted to \\ The School of Dentistry \\ At West Virginia University \\ In partial fulfillment of the requirements for the degree of \\ Master of Science \\ In \\ Orthodontics
}

Timothy Tremont D.M.D., M.S. Chair

Peter Ngan, D.M.D.

Chris Martin, D.D.S., M.S.

Richard Jurevic, D.M.D, M.S.

Department of Orthodontics

Morgantown, West Virginia

2016

Keywords: Alveolar bone, basal bone, WALA Ridge

Copyright 2016 Dr. Timothy Glass 


\title{
Abstract \\ A CBCT EVALUATION OF ROOT POSITION WITHIN BONE, LONG AXIS INCLINATION, AND THE WALA RIDGE
}

\author{
Timothy R. Glass, D.D.S.,
}

Background and Objectives: Correct tooth position in all planes of space while respecting the boundaries of the underlying bone has been proposed as a necessary hallmark to providing a foundation of stability for the teeth as well as the supporting periodontium. The aim of this study was to determine 1) If teeth centeredness over basal bone improves when teeth are more upright or approach WALA Ridge norms 2) If teeth centeredness in alveolar bone improves when teeth are more upright or approach WALA Ridge norms 3) If the WALA ridge is located at or near the estimated center of resistance of molar and premolar teeth. Methods: 34 pre-treatment CBCT and mandibular cast samples of patients ages 12-18 were randomly selected and analyzed. WALA ridge cast measurements were transferred to CBCT images. The centeredness of the teeth within bone was then quantified. The WALA Ridge location was measured and compared to the center of resistance location. Results: 1) No statistical significance was found across the board for centeredness of teeth over basal bone when they are more upright or approach WALA Ridge norms. 2) No statistical significance was found across the board for centeredness of teeth in alveolar bone when they are more upright or approach WALA Ridge norms. 3)Statistical significance ( $p$-value <.05) was found for the center of resistance and WALA Ridge being located at or near each other for all mandibular posterior teeth. 4) Statistical significance ( $p$-value <.05) was found for posterior teeth center of resistance being centered in the alveolar bone regardless of the long axis inclination or WALA Ridge norms. Conclusion: 1) More upright posterior teeth based on long axis inclination or teeth more closely related to the WALA ridge landmark are not more centered over basal bone. 2) More upright posterior teeth based on long axis inclination or teeth more closely related to the WALA ridge landmark are not more centered in alveolar bone. 3) The WALA Ridge soft tissue landmark is located at or near the center of resistance for all posterior teeth. 4) The center of resistance of all posterior teeth can most often be found in the center of the alveolar bone regardless of inclination. 


\section{CONTENTS}

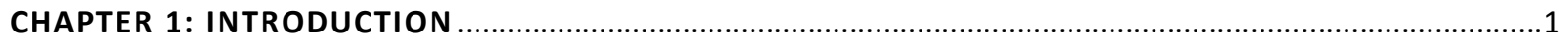

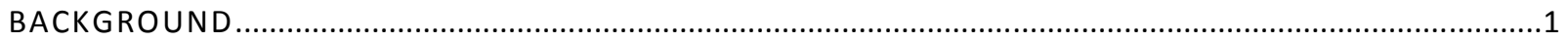

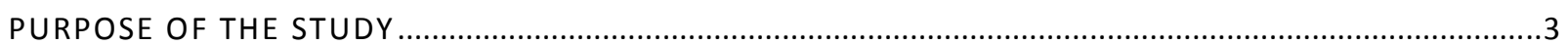

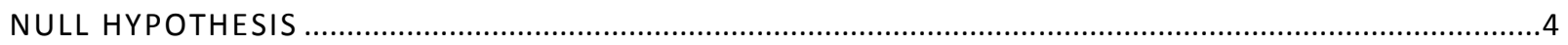

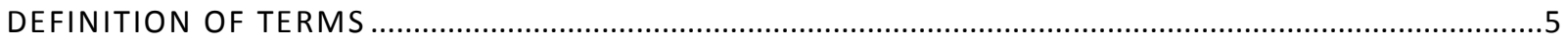

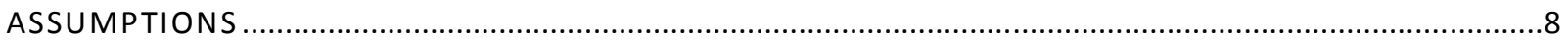

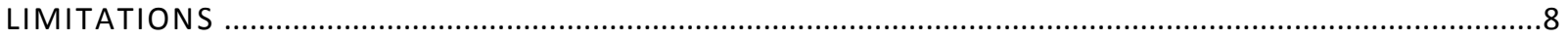

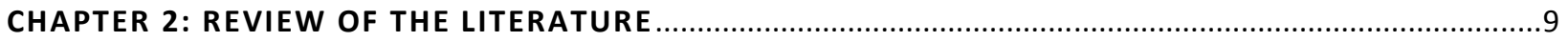

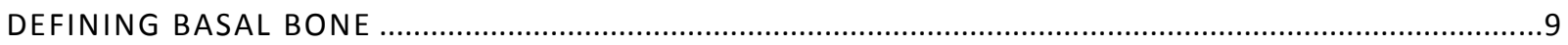

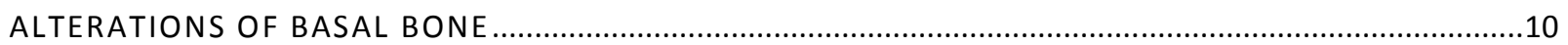

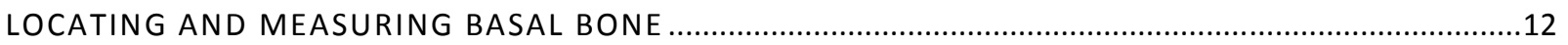

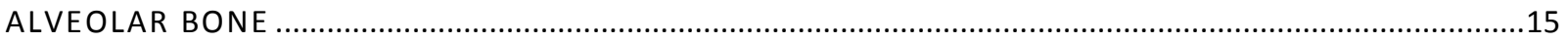

PERIODONTAL CONSIDERATIONS WITH ORTHODONTIC TOOTH MOVEMENT .................................17

CONE BEAM COMPUTED TOMOGRAPHY (CBCT) IN ORTHODONTICS ...........................................20

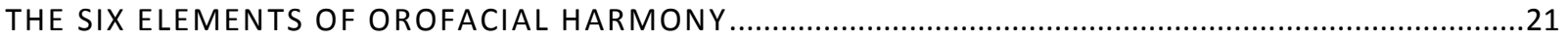

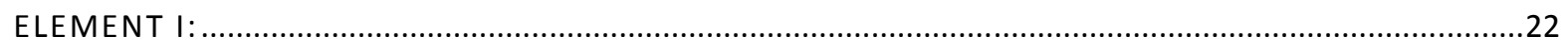

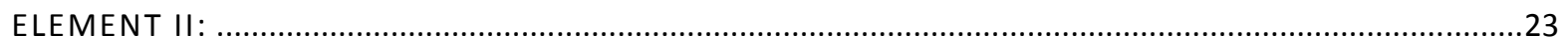

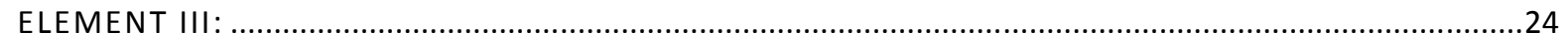

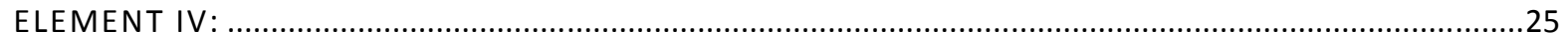

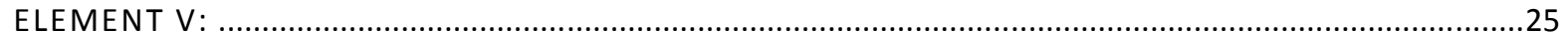

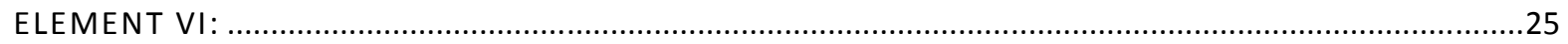

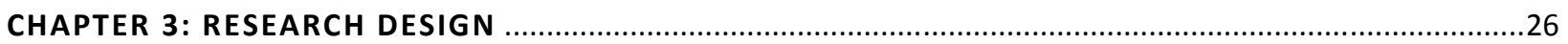

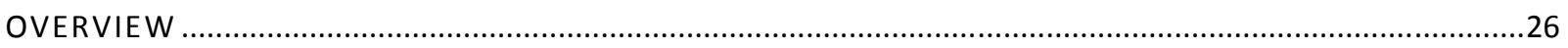

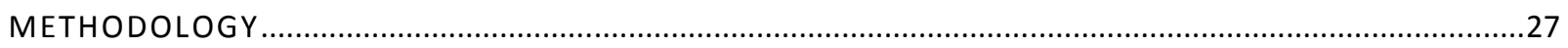

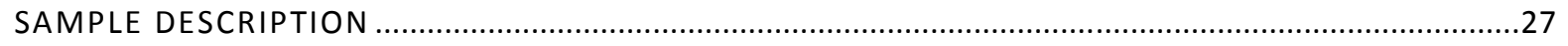

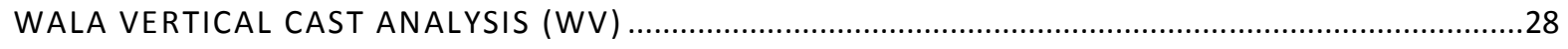




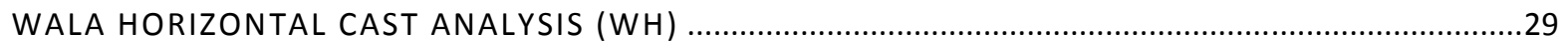

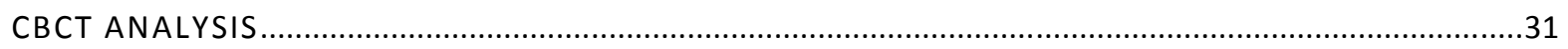

CONSTRUCTION OF REFERENCE OCCLUSAL PLANE \& LONG AXIS INCLINATION ANALYSIS ............32

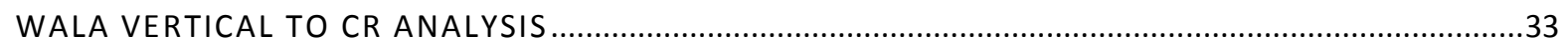

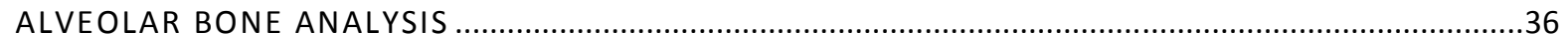

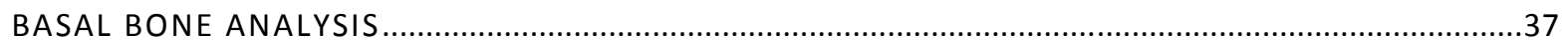

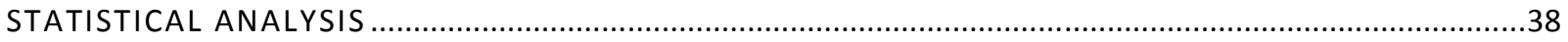

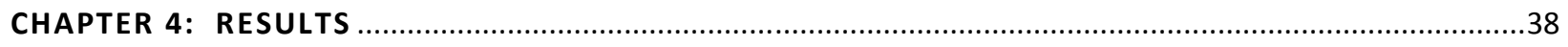

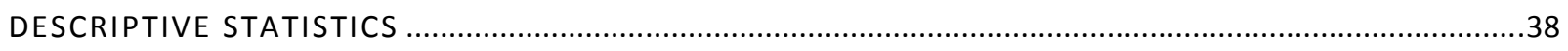

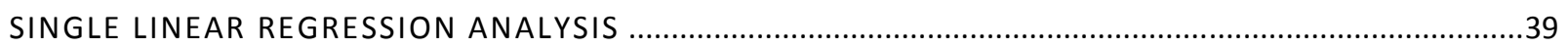

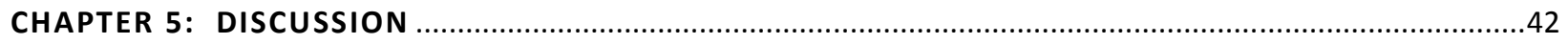

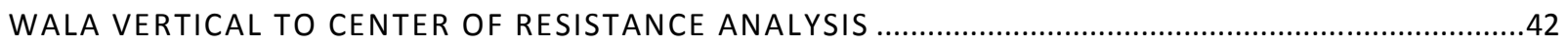

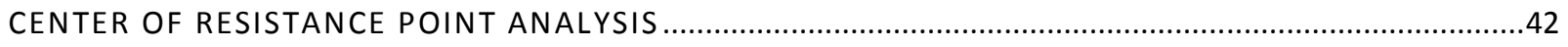

LONG AXIS INCLINATION ANALYSIS AT D1, D2, \& D3

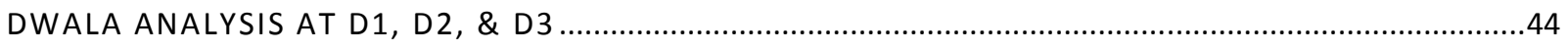

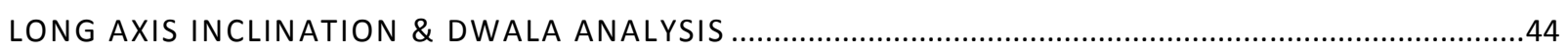

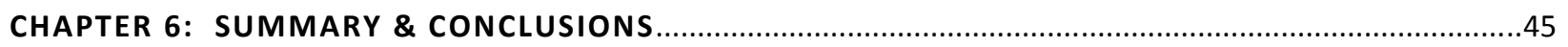

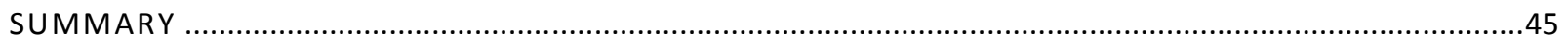

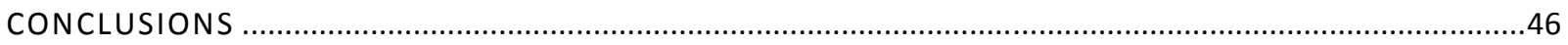

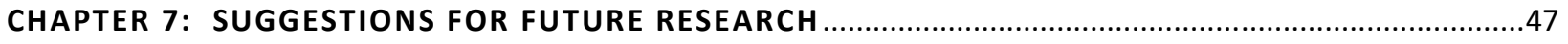

WORKS CITED

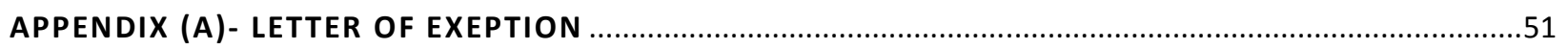

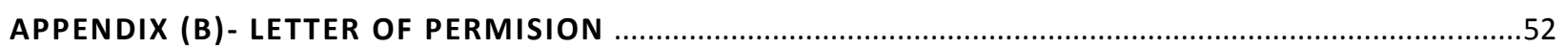

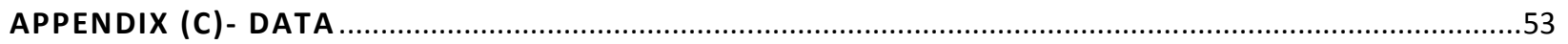


CHAPTER 1: INTRODUCTION

\section{BACKGROUND}

Correct tooth position in all planes of space while respecting the boundaries of the underlying bone has been proposed as a necessary hallmark to providing a foundation of stability for the teeth as well as the supporting periodontium. Although this correct tooth position has been investigated over many decades, clinicians are still divided, and the extraction versus non-extraction debate continues to live on. It is generally believed that when tooth mass is too small relative to basal bone, interdental spacing or diastemas will likely occur ${ }^{1}$. Conversely, if the basal bone in the body of the mandible is constricted or too small relative to tooth mass, the teeth will be crowded ${ }^{2}$. To this point, successful alignment of the teeth, among other factors, is dependent on the size of the basal bone in relation to the tooth mass ${ }^{1}$. Does this mean that teeth should be centered over basal bone? What is basal bone and how does it differ, if at all, from alveolar bone? Should we abandon the term "basal bone" and refer to teeth being centered in alveolar bone or over "the ridge"? With the use of CBCT imaging becoming more prevalent the search for these answers are being revisited because of the profound clinical implications involved. For so many years orthodontics has been performed on a 2D basis using mainly panoramic and cephalometric films. Now that 3D CBCT technology has become so widely available new attempts to answer or at least clarify these questions have begun.

The term "basal bone" has been used loosely for decades to describe the bone over which teeth should be positioned in order to have superior stability in both function and health. 
According to common authors, basal bone is the bone that underlies, supports, and is continuous with the alveolar process ${ }^{3}$. The term "apical base" was first introduced by Lundstrom in 1923 but failed to stimulate a sufficient response until Tweed presented it again in 1944 as basal bone. Tweed defined basal bone as the bony ridge over which the mandibular central incisors must be situated to produce permanence of Orthodontic results. The focus of Tweeds research was to find the most stable lower incisor position relative to the underlying basal bone to combat post orthodontic relapse. Lundstrom (1925) theorized that the apical base did not change to fit the normal occlusion but rather the establishment of normal occlusion was controlled by the apical base. In contrast Damon (2005) suggested that the use of light continuous orthodontic force could be used in crowded cases to expand the alveolar bone and maintain its integrity. Many studies including some conducted by Howes (1947) and Downs (1948) have attempted to locate basal bone with little consensus. Not surprisingly, confusion still exists among clinicians and researchers as to the location of basal bone and its true relevance to stable clinical orthodontic treatment.

The Six Elements of Orofacial Harmony developed by Doctor Larry Andrews presents a set of parameters and guidelines to aid in obtaining optimal goals for the teeth, arches, and jaws. Element I infer an optimal arch when teeth are centered over basal bone and each crown is inclined so that its occlusal surface can interface and function optimally with the teeth in the opposing $\operatorname{arch}^{4}$. The key statement is function optimally. In order for teeth to resist post treatment relapse there must be an environment of equilibrium between the masticatory muscles, temporomandibular joint and opposing dentition. When treatment goals include centering teeth in the bone many new avenues begin to become apparent to the treating 
clinician. There are many schools of thought that do not believe maxillary rapid palatal expansion is indicated or necessary in the absence of a cross bite. Many dentitions present with teeth that are compensated due to underlying skeletal deficiencies. For example, maxillary arches that are constricted in the absence of a cross bite would actually present as a cross bite if the upper and lower dentition were centered in bone. As the lingually inclined mandibular teeth are uprighted the cross bite that was not so apparent begins to come out of the shadow and the true skeletal deficiency begins to show. This skeletal deficiency in the maxilla becomes even more pronounced when the maxillary posterior dentition is decompensated and tipped more lingual. Now by centering the teeth in the bone the clinician can more accurately assess the need for orthopedic correction and allow occlusal forces to be directed down the long axis of the teeth where there is more bony support. Andrews proposed the WALA Ridge in 2000 to serve as a primary landmark for assessing mandibular arch shape and providing a template for the maxillary transverse width. The WALA ridge is a band of soft tissue immediately coronal to the mucogingival junction of the mandible and being at or near the level of the center of rotation of the teeth ${ }^{4}$. This landmark aids the clinician in establishing the correct arch form leading to the most ideal tooth position in the maxilla and mandible relative to the basal bone ${ }^{4}$.

\section{PURPOSE OF THE STUDY}

The objectives of this study are:

1. To investigate if the roots of more optimally inclined posterior teeth as defined by the long axis inclination and WALA Ridge are more centered over basal bone. 
2. To investigate if the roots of more optimally inclined teeth as defined by the long axis inclination and WALA Ridge are more centered in alveolar bone.

3. To investigate if the estimated center of resistance point is most often centered in alveolar bone, validating the need to simply tip teeth to their ideal position.

4. To investigate if the current concept of "centeredness over basal bone" is ambiguous and the term alveolar arch or ridge is a more accurate description due to its clinical application and the fact that the alveolar process is the investing structure of the teeth.

5. To investigate if the WALA ridge is located at or near the estimated center of resistance of molar and premolar teeth.

\section{NULL HYPOTHESIS}

1. The root apices of teeth with FA points more optimally related to the WALA Ridge are not more centered over basal bone.

2. The center of resistance of teeth with FA points more optimally related to the WALA Ridge are not more centered in alveolar bone.

3. The root apices of teeth with FA points more optimally related to the WALA Ridge are not more centered in alveolar bone.

4. The root apices of more upright posterior teeth based on the long axis inclination are not more centered over basal bone.

5. The center of resistance of more upright posterior teeth based on the long axis inclination are not more centered in alveolar bone.

6. The root apices of more upright posterior teeth based on the long axis inclination are not more centered in alveolar bone.

7. The FA point of more upright posterior teeth based on long axis inclination are not more related to the WALA Ridge per Andrews' Element 1.

8. The WALA ridge soft tissue landmark is not located at or near the center of resistance of premolar and molar teeth.

9. The center of resistance point is most often not centered in the alveolar bone. 


\section{DEFINITION OF TERMS}

Alveolar Bone - is a specialized part of the mandibular and maxillary bones that forms the primary support structure for teeth and is subjected to continual and rapid remodeling associated with tooth eruption and subsequently the functional demands of mastication.

Apical Base/Basal Bone - 1. Orthodontic term defining a horizontal plane coincident with the region of bone in which the apices of the roots are located. 2 . The apical third of the alveolus and the bone that supports the alveolar processes below the mandibular teeth.

Buccal - Term referring to the tooth surface of posterior teeth that lies adjacent to the cheeks.

Center of Resistance - considering the tooth in its alveolus, it is that point through which a pure force would result in translation of the tooth without any rotational effect; for a given tooth the center of resistance is found at approximately one-third ( 0.3 to 0.5$)$ of the distance from the alveolar crest to the apex, and its location does not change (unless root length or alveolar crest height changes).

Center of Rotation - a point around which all points on the tooth rotate; the center of rotation can change depending upon the forces and moments acting upon the tooth.

Centric relation - the maxillomandibular relationship in which the condyles articulate with the thinnest avascular portion of their respective disks with the complex in the most anterior-superior position against the shapes of the articular eminencies. 
Cone Beam Computed Tomography (CBCT) - is a medical imaging technique consisting of Xray computed tomography where the X-rays are divergent, forming a cone.

Customized Arch Wire - A commercially produced archwire that is modified in shape by the doctor to uniquely fit each individual patient.

Dehiscence- A defect that results in lowering of the crestal bone margin to expose the root surface.

Element I-The position in which a tooth is centered in basal bone with proper inclination for optimal occlusion.

Element III - Distance between the mesio-lingual cusp tips of the right and left "Element I" maxillary first molar is equal to the distance between the central fossae of the right and left "Element I" mandibular first molar.

Facial Axis of the Clinical Crown (FACC) - For all teeth except molars, the most prominent portion of the central lobe on each crown's facial surface; for molars, the buccal groove that separates the two large facial cusps.

FA Point - The point on the facial axis of the clinical crown that separates the gingival half of the clinical crown from the occlusal half.

Fenestration- Isolated areas in which the root is denuded of bone, and the root surface is covered only by periosteum and overlying gingiva.

Gingival - Term relating movement of an object or location of that object relative to the gingival tissues. 
Gingival Recession- Displacement of the soft tissue margin apical t the cementoenamel junction with exposure of the root surface.

Inclination - the tilt of the long axis of a tooth in the buccolingual or faciolingual direction.

Key I - Interarch relationships: (1) the mesiobuccal cusp of the maxillary first molar occludes in the mesio-buccal groove of the mandibular first molar; (2) the distal marginal ridge of the maxillary first molar occludes on the mesial marginal ridge of the mandibular first molar; (3) the mesiolingual cusp of the maxillary first molar occludes in the central fossa of the mandibular first molar; (4) the buccal cusps of the maxillary premolars rest in the embrasures of the mandibular premolars; (5) the lingual cusps of the maxillary premolars rest in the fossae of the mandibular premolars; (6) the maxillary incisors overlap the mandibular incisors and the midlines of the maxillary and mandibular arch are coincident Landmark- a point or line that represents anatomy that is actually or hypothetically positioned correct that can be used to measure the quality of the position of anatomy that may or may not be positioned incorrect.

Lingual - Term referring to the tooth surface that lies adjacent to the tongue.

Occlusal - Dental term relating to movement of an object of location of that object relative to the chewing surfaces of the teeth.

Occlusal Plane - The occlusal plane defined by as Andrews as a line connecting the distal marginal ridge of the maxillary first premolar and the distal marginal ridge of the maxillary first molar. 
Preformed Archwire - A commercially shaped archwire that is produced on mass scales to yield identical wire shape from one lot to the next.

Root Apex - the terminal end of the root of the tooth farthest from the incisal or occlusal side.

WALA Ridge - A band of soft tissue immediately superior to the mandible's mucogingival junction, that is at, or nearly at, the same superior or inferior level as the horizontal center of rotation of the teeth in an arch.

WALA Horizontal - Distance from the tooth FA point to the WALA ridge.

WALA Vertical - The distance from the occlusal table to the WALA ridge.

\section{ASSUMPTIONS}

1. All CBCT images are 1:1 with no need for calibration.

2. All orthodontic casts and $\mathrm{CBCT}$ images are pre-treatment.

3. The reference occlusal plane, as identified in this study, is an accurate representation of the line of occlusion and can be accurately identified.

\section{LIMITATIONS}

1. Coronal CBCT slices are not standardized.

2. Root morphologies are not standardized.

3. Center of resistance point is an estimated point.

4. WALA ridge is an estimated landmark.

5. Alveolar and basal bone boundaries are not always distinct on CBCT.

6. Operator error may be present since all measurements have been made with one operator. 


\section{CHAPTER 2: REVIEW OF THE LITERATURE}

\section{DEFINING BASAL BONE}

The terms basal bone and apical base are used interchangeably in the literature. Basal bone as defined by common authors is the bone that underlies, supports, and is continuous with the alveolar process ${ }^{3}$. The term "apical base" was first introduced by Lundstrom in 1923. He defined the apical base as the section of bone upon which the teeth rest or are attached. This concept failed to stimulate a sufficient response until Tweed introduced it as basal bone in 1944. At this time Tweed focused his research on placing the lower incisors upright over basal bone to enhance long term stability. Tweed defined basal bone as the bony ridge over which the mandibular central incisor must be situated to produce permanence of orthodontic results. In 1948 Salzmann expanded on the definition to include the area in the jaws which begins at the most constricted point on the body of the maxilla and mandible when seen on a lateral cephalogram. This area included Downs' Point A, Point B, and Lundstrom's apical base and it extends around the body of the maxilla or mandible at the most constricted portions parallel to the alveolar process ${ }^{5}$. At this point in time no one had actually successfully defined or at least applied the basal bone concept clinically with research to support its use. According to Brodie the reason for this lack of definition of the apical base was the limitation of available methods ${ }^{6}$. 
"We have never investigated the so-called apical base, and the reason is not hard to find. There is no method yet devised which will permit its accurate determination. The term has never been satisfactorily defined, yet each person practicing orthodontia seems to be quite certain of what is meant by the term. Upon critical questioning, however, the definition becomes vague ${ }^{6} . "($ Brodie, 1950)

However, he suggested that after the teeth are lost and the alveolar bone resorbs the limits of the apical base may be better determined ${ }^{6}$.

\section{ALTERATIONS OF BASAL BONE}

The transverse dimension in terms of basal bone modification is a controversial subject among orthodontist ${ }^{7}$. Although the question whether basal bone is immutable or not has been debated ever since the days of Edward Angle, many clinicians still debate whether it is possible to alter the skeletal width of the maxilla or the mandible through either orthodontic or orthopedic treatment ${ }^{7,8}$. Contemporary practice has directed attention to the mandibular arch as the most limiting and therefore, of first consideration for diagnosis ${ }^{9}$.

Angle believed that each tooth positioned in its proper place has a definitive role in the development of the jaws and that "bone growing" is possible under the concept of functional development ${ }^{8,10}$. He argued that a full complement of teeth can and must be maintained when correcting any case of malocclusion ${ }^{10}$. Frankel suggested that the dynamics of eruption could be utilized to increase the alveolar growth by using vestibular shields ${ }^{8,11}$. The functional 
regulator appliance was used to displace the attachment of the lips and cheeks at the sulci in an outward direction resulting in greater development of the basal bone ${ }^{8,11}$. Under the Functional Matrix Theory proposed by Moss in the mid 1900's it was theorized that the teeth were a functional matrix for alveolar growth ${ }^{12}$. He argued that by changing the muscular forces applied to the denture, expansion occurs as a secondary response and therefore can only be stable if the new functional matrix supports this change ${ }^{12}$. As the continued growth and eruption of the teeth proceed, induction of alveolar growth could occur with the formation of an adequate bony support ${ }^{12}$. Fast forwarding to 2005, Damon developed his philosophy of using resilient copper-nickel-titanium (CUNITI) wires to distribute expansion forces much gentler than Angle's gold, German silver, or chrome steel wires ever could provide ${ }^{13,14}$. He suggested that the use of light forces in crowding cases could expand alveolar bone while maintaining its integrity ${ }^{13}$. His approach maintains force levels in what he calls the "optimal force zone" to alter the balance of forces among the lips, tongue, and muscles of the face creating a new force equilibrium ${ }^{13}$.

In contrast to the previous authors some believe that the apical base is unable to be modified. Lundstrom made a landmark contribution to orthodontics when he proposed a theory that the apical base did not change to fit the normal occlusion, but rather the establishment of normal occlusion was controlled by the apical base ${ }^{15}$. This belief contradicted and criticized the previous teachings of Angle. Salzmann was in support of Lundstrom's theory, adding to the unaltered nature of basal bone ${ }^{5}$. He felt that no matter how the teeth and alveolar process were modified by orthodontic means into different occlusal relationships the basal arch would be static ${ }^{5}$. Strang believed that denture expansion as a treatment procedure 
in the correction of malocclusion should be discarded and every effort should be directed toward preserving the muscular balance ${ }^{16}$. He felt that muscular balance could not be ignored or modified and was just as inflexible as in the growth pattern of the basal bone ${ }^{16}$. A couple years later Brodie stated that extractions were used to accommodate the dentition to the osseous base which was genetically predetermined in size and therefore described the apical base as immutable ${ }^{6}$. Howes argued that if you compare the basal bone arch form of a patient at 5 years of age versus 15 years of age there is no difference in form or shape even though the form at the coronal level has change to allow for the eruption of the permanent teeth ${ }^{17} \mathrm{~A}$ more recent study by Vanarsdall confirmed the fact that standard edgewise orthodontic treatment does not have any effect on the basal structure of the maxilla or mandible ${ }^{7}$.

\section{LOCATING AND MEASURING BASAL BONE}

Although the definition of basal bone clearly describes an area that underlies the teeth apices, clinicians have used many different methods to locate and quantify basal bone ${ }^{8}$. Historically clinicians have assessed the apical base by clinical palpation or interpretation of cephalometric radiographs ${ }^{18}$. Downs introduced two cephalometric landmarks, A point and B point, to represent what he called the denture base ${ }^{19}$. He was interested in studying the skeletal patterns of the face and used these points and others to develop his classic cephalometric analysis. Riedel developed two angular measurements, SNA and SNB, from Downs $A$ and $B$ points to assess the apical base relationships in the sagittal dimension. Although this method describes the location of the anterior limits of the apical base it does not quantify its size ${ }^{18}$. 
Howes was one of the first researchers to attempt to measure tooth size and supporting bone and used dental casts for his analysis ${ }^{20}$. He found that the supporting bone was above the palatal shelf and over the apices of the teeth ${ }^{20}$. By using a survey line above the apices of the teeth without impinging on the mucobuccal fold and sectioning horizontally on this line, he was able to remove the alveolar process and expose the supporting bone ${ }^{20}$. He found the basal arch to be in the apical one-third of the alveolar bone in the maxilla and $8 \mathrm{~mm}$ below the gingival margin in the mandibular arch ${ }^{20}$. Rees also conducted a study using plaster models and found the apical base to be 8 to $10 \mathrm{~mm}$ apical to the gingival margin ${ }^{21}$.

Falck defined the apical base as the area resulting from peripheral connection of two reference points located $14 \mathrm{~mm}$ away from buccal cusps of the primary first molars/premolars ${ }^{22}$. Given that the primary molars have shorter cusps than the premolars; Miethke et al. argued that Falck's method of locating the apical base was inaccurate for comparing treatment outcomes $^{23}$. The difference in the crown heights between these two tooth types would change reference points and thus change the apical base level ${ }^{23}$. To overcome this limitation Miethke used gingival margins as a reference point similar to Howes and Rees ${ }^{23}$. He studied the effects of Frankel's functional regulator on apical base dimensions. Miethke et al. defined the apical base as the peripheral connection of six referenced landmarks $5 \mathrm{~mm}$ below the most apical points of the gingival margins of the lower lateral incisors, canines, and second primary molars or premolars ${ }^{23}$. In contrast to some authors using gingival margins to locate basal bone, Sergl, Kerr, and McColl used the most concave contour of the buccal surface of the casts to measure the basal bone area ${ }^{18}$. 
Most recently Kanaan and Bell conducted research to assess basal bone looking at traditional cephalometric radiographs and CBCT. Kanaan measured basal bone perimeters from traditionally available orthodontic records including dental plaster casts and cephelograms ${ }^{8}$. The posterior limit of basal bone was defined as being perpendicular to the functional occlusal plane mesial to the first molars ${ }^{8}$. Basal bone depth was determined by locating $B$ point and creating a horizontal plane parallel to the functional occlusal plane using the cephalometric radiograph ${ }^{8}$. The measurements were then transferred to the dental casts, which was sectioned to expose the basal bone shelf ${ }^{8}$. Estimates of the perimeter were made from the basal bone shelf with stainless steel wires and an elliptical formula; however the perimeter measurements did not take soft tissue anterior ridge thickness into consideration ${ }^{8}$. Bell used cone beam computerized tomography in his study to demonstrate that basal bone at the level of $B$ point was very similar to basal bone at a level below the root tips demonstrating that it is not necessary to consider bone lower than B point in order to have continuous CBCT slices back to the second molars ${ }^{1}$. This study also denied strongly held beliefs that basal bone, alveolar bone, and teeth have a strong relationship; it found significant correlations between crowding and basal bone dimensions, although correlations were low and of little value in explaining the relationships that were investigated. A study by Weaver in 2012 demonstrated a significant correlation between the dental width and basal bone arch width based on the WALA ridge ${ }^{24}$. Other works agreed that defining basal bone according to the WALA ridge was a relatively simple clinical method of defining basal bone and that the arch shape at the crown level is of sufficiency to base treatment archwires ${ }^{25-27}$. 
Based on the literature review there is no standard way of locating and measuring the apical base. With the advent of CBCT there may be some hope of eliminating the ambiguity and standardizing the reporting in the literature about the definition of basal bone to further support the idea that the arch form at the crown level is no different from the bone level.

\section{ALVEOLAR BONE}

Alveolar bone is a specialized part of the maxillary and mandibular bones that forms the primary support structure for teeth and is dependent upon the presence of teeth for its preservation ${ }^{28}$. It is subjected to continual and rapid remodeling associated with tooth eruption and subsequently the functional demands of mastication ${ }^{28}$. This ability to undergo rapid remodeling is also important for the positional adaptation of the teeth but may be detrimental to the progression of periodontal disease ${ }^{28}$. Alveolar bone comprises the alveolar process, which is an extension of the basal bone of the jaws which develop from the first brachial arch under the direction of homeobox gene expression ${ }^{28}$. The alveolar bone forms in relation to the teeth but structurally it is similar to, and continuous with, the basal bone ${ }^{28}$. While the growth and development of the jaw bones determines the position of the teeth, a certain degree of repositioning of teeth can be accomplished through occlusal forces and in response to orthodontic procedures that rely on the adaptability of the alveolar bone and associated periodontal tissues ${ }^{28}$.

Complete remodeling of the alveolar bone occurs when the primary dentition is replaced by succedaneous teeth ${ }^{28}$. The alveolar bone associated with the primary tooth is completely resorbed together with the roots of the tooth while new alveolar bone is formed to 
support the newly erupted tooth ${ }^{28}$. Significant remodeling of the alveolar process also occurs as part of this process. The ability of the alveolar bone to remodel rapidly also facilitates positional adaptation of teeth in response to functional forces and in the physiological drift of teeth that occurs with the development of the jaw bones ${ }^{28}$. Although there are architectural specifications for alveolar bone that relate to its functional role, the basic cellular and matrix components are consistent with other bone tissues ${ }^{28}$.

The effect of orthodontic treatment and various appliances on alveolar bone morphology and boundary conditions in three planes of space can be assessed relatively well with CBCT. Alveolar boundary conditions are the depth, height, and morphology of the alveolar bone relative to tooth root dimensions, angulation, and spatial position ${ }^{29}$. Boundary conditions are determined not only by dentoalveolar anatomy prior to treatment, but also by the bone's adaptability during tooth movement and its morphology following the final positioning of the teeth $^{29}$. Thus, in the context of orthodontic tooth movement, boundary conditions can be considered to be dynamic and dependent on the patient's pre-treatment bone and gingival biotype as well as bone physiology ${ }^{29}$. This implies that pre-treatment status of alveolar boundary conditions and their potential adaptation may dictate the limits of both the planned tooth movement and the final desired spatial position and angulation of the tooth ${ }^{29}$. Failure to stay within the alveolar bone has significant and often irreversible negative sequelae, such as dehiscences and fenestrations ${ }^{29}$.

Alveolar bone adaptation is a critical aspect to the Damon system and other self-ligating products that advocate the use of light forces in crowding cases to expand alveolar bone while 
maintaining its integrity ${ }^{13}$. The Damon system claims the ability to create a new force equilibrium that allows the arch to reshape itself to accommodate the teeth, with the new arch form determined by the body and not by the clinician or the system applied ${ }^{30}$. However it is not clear how this system can deliver such a fine-tuned balance given the fact that even extremely low forces have been shown to be sufficient to displace teeth ${ }^{30}$. Cattaneo et al. in 2011 conducted a randomized clinical trial to evaluate the effects of treatment with passive and active self-ligating brackets using $\mathrm{CBCT}$. This study evaluated the type of tooth movement, amount of alveolar bone buccal to the second premolar, and buccal bone augmentation before and after treatment in the maxilla. The results of this study revealed that no claims of true expansion, buccal bone apposition, or Frankel-like effects could be verified. Although selfligating appliances such as the Damon system have been established for almost 20 years, there are no published detailed investigations of arch dimensional changes related to treatment with self-ligating systems ${ }^{31}$. Consequently, the implications of treatment with such appliances on long term stability remain unclear ${ }^{31}$. There have been a number of isolated case reports documenting dimensional changes with the Damon appliance system ${ }^{32,33}$. These cases have described inter-molar width increases exceeding $10 \mathrm{~mm}$ allowing non-extraction treatment; the long term stability of such significant changes is likely to be reliant on permanent retention. However, most advocates of self-ligating appliances do not aim for such expansion, preferring to maintain pretreatment dimensions where possible.

PERIODONTAL CONSIDERATIONS WITH ORTHODONTIC TOOTH MOVEMENT 
The periodontium, which is an integral part of the dentoalveolar complex, requires thorough evaluation, diagnosis and treatment sequencing as part of the orthodontic treatment process $^{34}$. The periodontal goal in orthodontic treatment has two components: health and aesthetics. Bleeding on probing and pocket depths are generally considered reliable indicators of active periodontal inflammation and must be managed successfully before orthodontic care can be started. In order to assure periodontal health, teeth must be in the bone in all three planes of space ${ }^{34}$. Centering teeth in the alveolar process and or over basal bone can help ensure that biological parameters are respected to avoid complications and negative treatment outcomes including but not limited to dehiscence, fenestration and gingival recession. Therefore, orthodontic tooth movement requires that final tooth position should provide appropriate osseous support. Periodontal aesthetics involves the relationship between gingival contours in adjacent teeth and opposing arches. In a healthy and well-balanced system, dental contours should be in harmony with gingival margins.

Gingival recession is described as exposure of the root surface by an apical shift in the position of the gingiva. Many factors may contribute to the development of recession including difficulty in plaque control due to fixed orthodontic appliances, coronally attached frenal and muscle attachments, abnormal tooth position, overhanging restorations or crowns, transverse expansion, proclination of teeth, fenestration, and dehiscence ${ }^{35}$. Clinically gingival recession is always accompanied by alveolar bone dehiscence however it has not been clarified whether underlying bone dehiscence is developed before or parallel with gingival recession ${ }^{36}$. Alveolar dehiscence is a defect that results in lowering of the crestal bone margin to expose the root surface $^{37}$. Fenestrations are isolated areas in which the root is denuded of bone, and the root 
surface is covered only by periosteum and overlying gingiva ${ }^{35}$. The occurrence of dehiscence and fenestration during orthodontic treatment depends on several factors such as the direction of movement, the frequency and magnitude of orthodontic force, and the volume and integrity of periodontal tissues ${ }^{38}$. Research has shown that facial tooth movement results in reduced facial gingival dimensions, whereas an increase in facial gingival dimension is seen after lingual movement ${ }^{39,40}$. It has been suggested that to avoid these complications, alveolar morphology should be determined before orthodontic therapy begins through CBCT imaging which shows bone topography and anatomy.

Animal experimentation has shown that predisposing bone dehiscence may be induced by uncontrolled labial expansion of teeth through the cortical plate increasing the susceptibility of those teeth to the development of gingival recession ${ }^{24}$. However, experimental studies have shown that labial bone reforms in the in the area of dehiscence with an intact junctional epithelium when the tooth is returned to its proper position with the root centered within the alveolar process ${ }^{41}$. Wennstrom showed that teeth that were moved orthodontically in a labial direction into areas with varying thickness and quality of marginal soft tissue, showed an apical displacement of the soft tissue margin and a reduced alveolar height ${ }^{42}$. This study suggested that regardless of the marginal gingival thickness, facial movement beyond the alveolar bone results in attachment loss.

In the permanent dentition, both the maxillary rapid expansion and the slow maxillary expansion may cause buccal bone dehiscence in the posterior teeth, mainly in patients with an initial thin buccal bone plate. Maxillary first premolars showed more critical bone dehiscences 
than the first molars during RME due to anatomical characteristics of the maxilla ${ }^{43}$. The maxillary first premolars are located in an area which becomes narrower upwards so that bodily buccal movement leads to much easier perforation of the alveolar bone ${ }^{43}$. First molars are located in an area that widens upwards usually avoiding negative consequences from expansion. Hyrax expanders were found to cause more extensive dehiscence than Haas type expanders ${ }^{43}$. The periodontal consequences of rapid maxillary expansion in the permanent dentition highlight the importance of early intervention. If RPE is accomplished during the deciduous and mixed dentition a greater orthopedic effect can be produced, limiting the movement of the anchor teeth ${ }^{43}$. Although expansion of the arch form has been shown to produce gingival recession when expressed beyond the alveolar bone, similar findings were seen when maxillary transverse discrepancies were not corrected ${ }^{24}$. Anzilotti determined that a transverse skeletal discrepancy is a risk marker for identifying patients susceptible to gingival recession and periodontal disease when discrepancies of $5 \mathrm{~mm}$ or greater go uncorrected. Therefore, expansion or lack of expansion of the arch form can be damaging to the periodontal patient. The key to maintaining attachment is to produce movement that results in tooth movements within the alveolar bone.

\section{CONE BEAM COMPUTED TOMOGRAPHY (CBCT) IN ORTHODONTICS}

Cone Beam Computed Tomography (CBCT) has gained much interest as a diagnostic tool in orthodontics since being first introduced comprehensively at the 2002 symposium titled "Craniofacial Imaging in the $21^{\text {st }}$ Century" 29 . The CBCT evolved from the original computerized tomography (CT) developed by Hounsfield in 1967. The main difference is that the CBCT allows 
for a single rotation versus a CT using multiple passes and stacking the slices into one image while also increasing the radiation exposure needed ${ }^{44}$. Given the exponentially increasing research and clinical information on a $\mathrm{CBCT}$, most clinicians can appreciate the benefit of its usefulness on patients presenting with specific clinical challenges, however its routine use on every orthodontic patient remains controversial. Since it is not clear that the information derived from CBCT enhances diagnosis or helps in modifying treatments in several case types, which is important particularly when weighed against the risk of radiation exposure, most clinicians at this time make use of the CBCT technology on a case by case basis ${ }^{29}$.

\section{THE SIX ELEMENTS OF OROFACIAL HARMONY}

The Andrews ${ }^{\circledR}$ Six Elements Orthodontic Philosophy ${ }^{\mathrm{TM}} 45$ is a complete analysis that provides a thorough diagnosis and leads to a custom treatment plan for each individual patient. The Six Elements of Orofacial Harmony" ${ }^{\mathrm{TM}}$ is defined by Lawrence F. Andrews as "six characteristics (within dentistry's milieu) that are essential for optimal orofacial health and appearance $^{45}$. The six characteristics include Element I: dental arch shape and length; Element II: anteroposterior jaw positions; Element III: buccolingual jaw positions; Element IV: superoinferior jaw positions; Element V: pogonion prominence and Element VI: dental occlusion. Andrews established a set of objectives, goals, landmarks and referents to define the optimality of each element. The Six Elements ${ }^{\mathrm{TM}}$ allows for a comprehensive classification system representing both the position of the teeth and the jaws. Andrews suggests that each Element be "uniquely correct for each person ${ }^{45}$. This classification system differs from 
traditional analyses; in that the position of the jaws and teeth are not based on cephalometric norms.

Below is a brief summary to provide an introduction to each Element. For a comprehensive guide to the Six Elements of Orofacial Harmony, please refer to the Andrews ${ }^{\circledR}$ Foundation course syllabus ${ }^{45}$. Dr. Andrews's study of optimal dental casts established the basis from which he developed the fully programmed Straight Wire Orthodontic Appliance. This discovery revolutionized contemporary orthodontic treatment.

\section{ELEMENT I:}

Element I describes the shape and length of the dental arches. An arch is optimal when teeth are positioned in the correct inclination, roots are centered in basal bone, and the curve of spee is between $0-2.5 \mathrm{~mm}$. The dental arch shape of the mandible is determined by evaluating the bucco-lingual distance between each tooth's facial-axis (FA) point and the WALA Ridge. The WALA ridge is the ridge of soft tissue directly superior to the mucogingival junction and is suggested to approximate the center of rotation of each tooth. The buccolingual distance between the FA point and the WALA ridge progressively decreases from posterior to anterior. The distance averages $2.2 \mathrm{~mm}$ at the second molar and $0.1 \mathrm{~mm}$ at the central incisor. The maxillary arch form is then established based on the mandibular arch form.

The lateral cephalometric radiograph is used to determine Element I incisors. The occlusal plane is first identified using the Andrews template to determine the proper inclination of the maxillary and mandibular central incisors with the roots centered in basal bone. The template incisor inclination relative to the occlusal plane ensures an optimal inclination $\left(7^{\circ}\right.$ for 
the maxillary incisor and $-1^{\circ}$ for the mandibular incisor) relative to the dental arch's perimeter line.

An evaluation of Element I will require an analysis of the core discrepancy (crowding). Calculations must be made to determine the effects that uprighting the molars, leveling the curve of Spee, expanding the maxilla and proclining/retroclining the incisors will create on the core discrepancy. These are used to determine the interim core discrepancy (ICD). A positive ICD indicates spacing whereas a negative ICD indicates crowding. The ICD is then utilized for treatment decisions such as the need for proclination, interproximal reduction, or extractions.

\section{ELEMENT II:}

Element II is an evaluation of the anteroposterior position of the jaws. The Goal Anterior Limit Line (GALL) represents the frontal plane of the head, and is identified based on an evaluation of the forehead shape and inclination. Three classifications of forehead shapes are determined; straight, angular, and round. The forehead points, trichion, superion, glabella and the foreheads facial axis point, are identified for each patient based on forehead shape. The distance between the forehead anterior limit line (FALL) and the dentition's anterior limit line (DALL) is evaluated clinically with the patient in an upright head position and recorded. The DALL is a line passing through the FA point of the maxillary incisor that parallels the frontal plane of the head. The FALL is a line passing through the FFA point of the forehead that parallels the frontal plane of the head. The angular measurement determined by the forehead inclination (superion and/or trichion to glabella) relative to the FALL is recorded. The FALL is equivalent to the GALL with a forehead inclination between $-7^{\circ}$ to $+7^{\circ}$. For every degree 
beyond the range $-7^{\circ}$ to $+7^{\circ}$, the GALL lies $0.6 \mathrm{~mm}$ anterior to the FALL, without exceeding glabella.

An optimal Element II maxilla requires the FA point of the maxillary central incisor to lie on the GALL. The maxilla can be classified as black (retrognathic) or red (prognathic) by measuring the distance from the maxillary incisor FA point to the GALL. An optimal Element II mandible is determined relative to an optimal Element II maxilla, with the teeth in an Element I position and a Key I dental relationship. The mandible can be classified as black (retrognathic) or red (prognathic) by measuring the distance from the optimal Element I and Element II maxillary incisor to the Element I mandibular incisor.

The AP jaw classification represents the jaw discrepancy relative to optimally positioned incisors. This is different from traditional cephalometric assessments which assess the jaw positions based on linear measurements or angles of specific jaw landmarks such as ANB.

ELEMENT III:

Element III is an evaluation of the transverse dimension of the maxilla relative to the mandible. The mandible represents the basis from which to measure the optimal bucco-lingual position of the maxilla. The cusp-cusp and fossa-fossa distances are measured within the maxilla and mandible with the teeth in an Element I position to determine if a discrepancy exists. If there is a discrepancy, the maxilla can be orthopedically or surgically expanded to match the mandibular width. The distance between FA point of the mandibular posterior teeth and WALA ridge, is used to determine the Element I tooth position and if uprighting is needed for mandibular posterior teeth inclined to the lingual. The amount of uprighting should be 
incorporated into the fossa-fossa transverse mandibular measurements to provide the most accurate transverse measurements.

\section{ELEMENT IV:}

The optimal jaw heights in the supero-inferior dimension are evaluated with Element IV. Jaw heights are optimal when: the teeth are in centric relation, the supero-inferior positions of the Element I maxillary central incisors are in harmony with the inferior border of the upper lip in repose, the occlusal plane inclination is between +2 and $+10 \cong$ relative to a patient in adjusted upright head position, and the lower anterior and posterior face heights are within $10 \mathrm{~mm}$ of the middle anterior face height.

\section{ELEMENT V:}

Element $\mathrm{V}$ is an evaluation of hard-tissue AP pogonion prominence. Element $\mathrm{V}$ is defined as optimal based on a pogonion prominence that lies on a line $90^{\circ}$ to the occlusal plane that passes through the FA point of the Element I mandibular incisor. The amount of deviation anterior or posterior to this line is recorded as positive or negative, respectively.

\section{ELEMENT VI:}

The Six Keys to Optimal Occlusion is the basis for Element VI. When all six keys are present, Element VI is considered optimal. Lawrence F. Andrews published The Six Keys to Normal Occlusion ${ }^{4}$ which he later modified the name to the Six Keys to Optimal Occlusion. Andrews studied 120 dental casts with optimal occlusions to determine if there were any universal characteristics that exist. Within these casts the constancy of features were found: Key; I) correct interarch relationships; II) correct crown angulation; III) correct crown inclination; 
IV) absence of rotations; V) tight contacts; and VI) a flat curve of Spee. These characteristics which define an optimal occlusion are widely used and accepted.

\section{CHAPTER 3: RESEARCH DESIGN}

\section{OVERVIEW}

IRB exemption was obtained by the West Virginia University Institutional review board prior to the start of this study (Appendix A). Pre-treatment orthodontic records including CBCT images and mandibular plaster casts were obtained retrospectively from Carl P. Roy Orthodontics in Virginia Beach, Virginia. The letter of permission from Carl P. Roy orthodontics was obtained (Appendix B). Cone Beam Computed Tomography (CBCT) images captured with an i-CAT CBCT machine were downloaded onto a Toshiba 1Tb external hard drive after being DE identified. The CBCT images were digitized and analyzed using Carestream 3D Imaging Software Version 3.5.7. Mandibular plaster casts were digitally scanned using the Ortho Insight 3D scanner from Motion View Software, LLC.

WALA horizontal measurements were measured using the Six Elements of Orofacial Harmony software developed by Lawrence F. Andrews and Motion View Software, LLC. WALA vertical measurements were obtained from the plaster casts by digital caliper. Coronal CBCT images were used to visualize and measure tooth positions of pre-treatment mandibular posterior teeth. 


\section{METHODOLOGY}

SAMPLE DESCRIPTION

34 samples were randomly selected from the private orthodontic practice of Dr. Carl P.

Roy in Virginia Beach, VA. Subject selection was based on the following:

Inclusion Criteria:

- Any patient $12-18$ years of age in the permanent dentition with no previous orthodontic treatment.

- A pretreatment cone beam computed tomography taken prior to orthodontic treatment.

- A Pretreatment mandibular cast taken prior to orthodontic treatment.

\section{Exclusion Criteria:}

- Presence of any craniofacial anomalies; e.g.: Cleft lip and palate.

- Absence of mandibular first and second molars.

- Absence of mandibular first and second premolars.

- Abnormal root morphology. 
- Any previous orthodontic treatment.

WALA VERTICAL CAST ANALYSIS (WV)

The WALA ridge landmark was identified on each plaster cast and marked with red pencil (Figure 1). A stainless steel endodontic ruler was then laid across the occlusal surface of each posterior tooth including second molar (M2), first molar (M1), second premolar (P2), and first premolar (P1) and its contralateral counterpart (Figure 2). A digital caliper was then used to measure the distance in millimeters from the top surface of the ruler to the WALA ridge on each tooth (Figure 3). $0.5 \mathrm{~mm}$ was subtracted from each measurement to account for the ruler thickness.

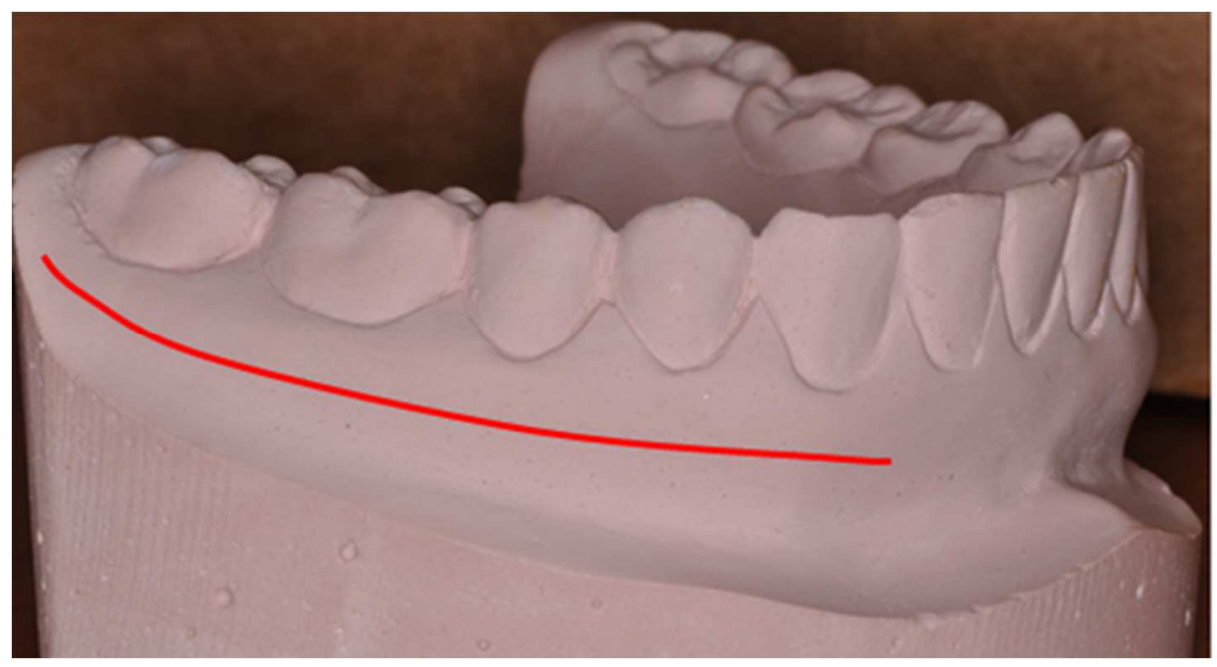

Figure 1: WALA Ridge Landmark 


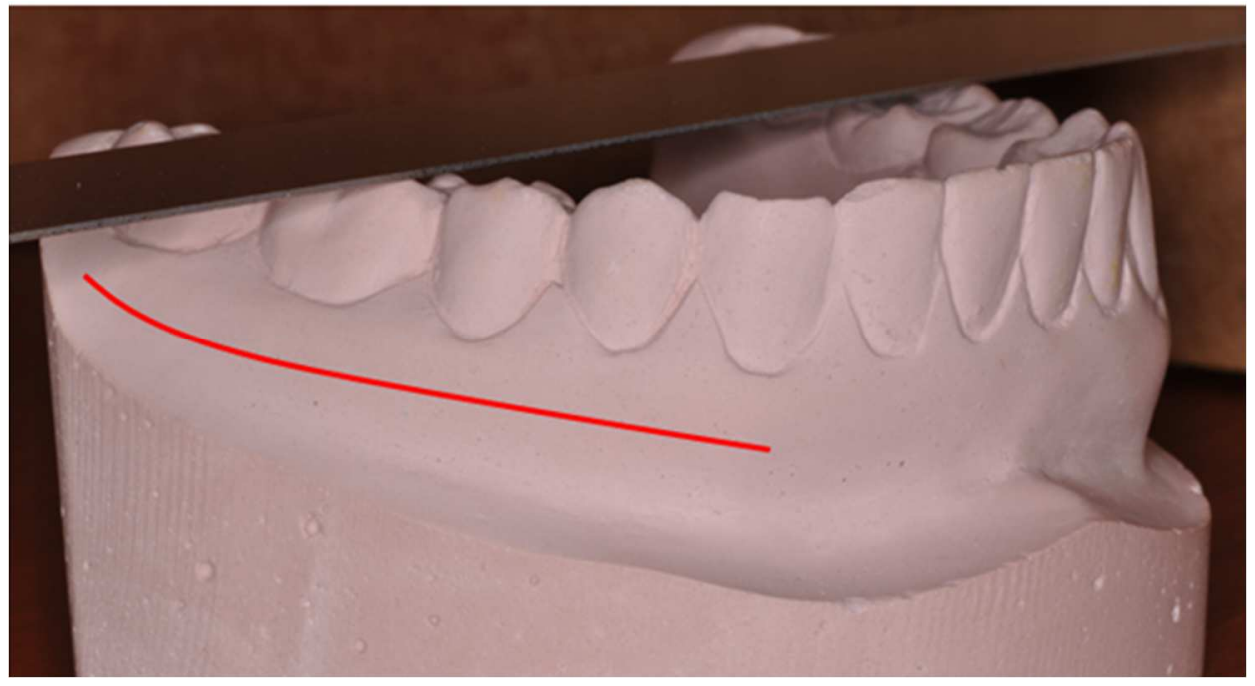

Figure 2: WALA Ridge Landmark \& reference occlusal plane

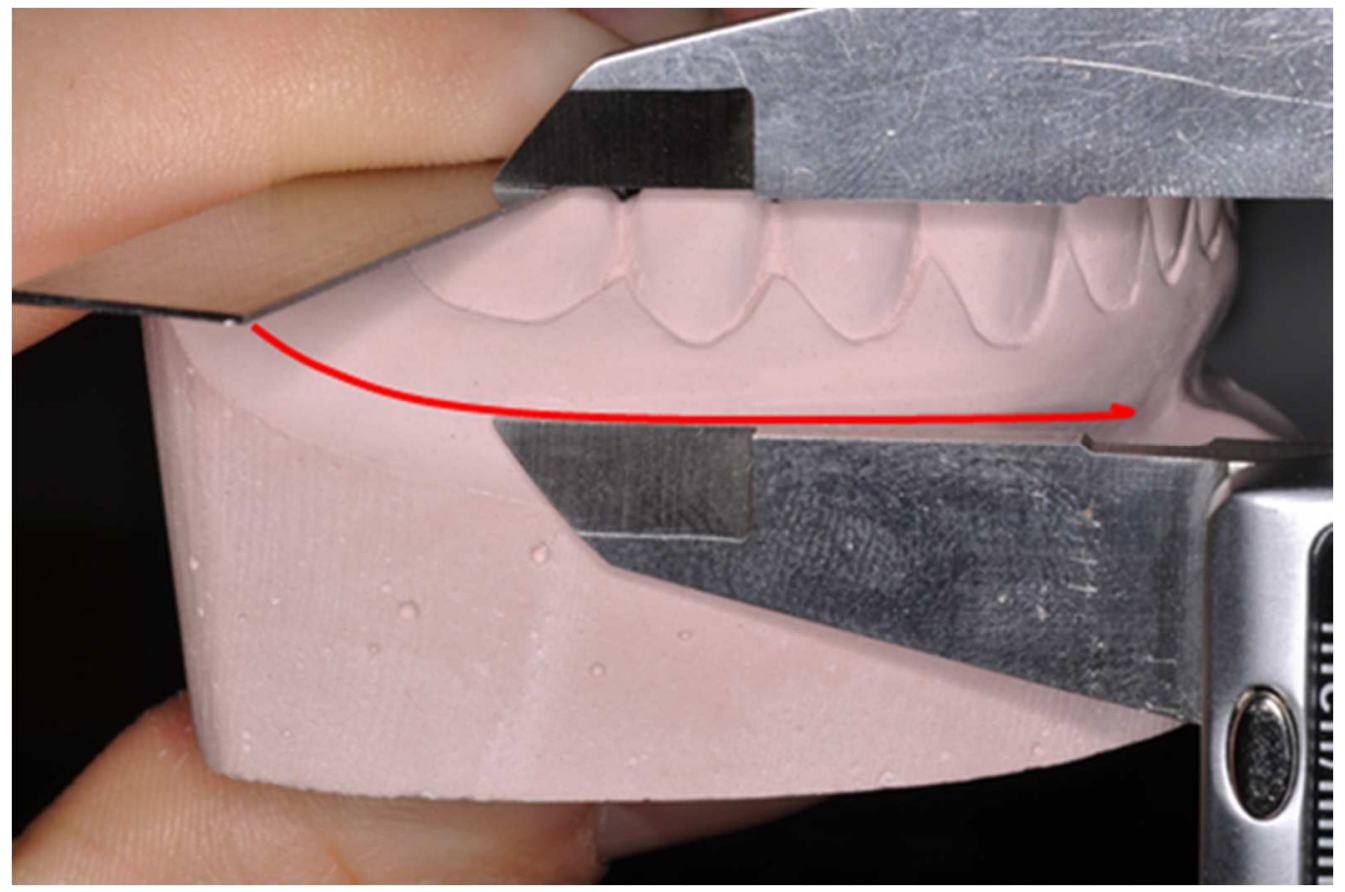

Figure 3: Illustration of WALA Vertical Measurement

WALA HORIZONTAL CAST ANALYSIS (WH) 
Mandibular casts were digitally scanned using the Ortho Insight 3D scanner from Motion View Software, LLC. Digital models were then calibrated and landmarks identified per the software specifications. WALA horizontal measurements of the second molars (M2), first molars (M1), second premolars (P2), and first premolars (P1) were obtained digitally using the Six Elements of Orofacial Harmony beta software module from Motion View Software, LLC (Figure 4). Once the WALA measurements were obtained and recorded, each of the values were subtracted from the norms proposed by Dr. Andrews (Table 1). This new value represents the difference between the actual and norm values and is defined as DWALA.

DWALA = WALA Horizontal - NORM

Table 1: WALA Ridge Norms

\begin{tabular}{|l|r|}
\hline \multicolumn{1}{|c|}{ Tooth Type } & \multicolumn{2}{c|}{$\begin{array}{c}\text { WALA Horizontal } \\
\text { Norms }\end{array}$} \\
\hline First Premolar & 0.8 \\
\hline Second Premolar & 1.3 \\
\hline First Molar & 2 \\
\hline Second Molar & 2.2 \\
\hline
\end{tabular}




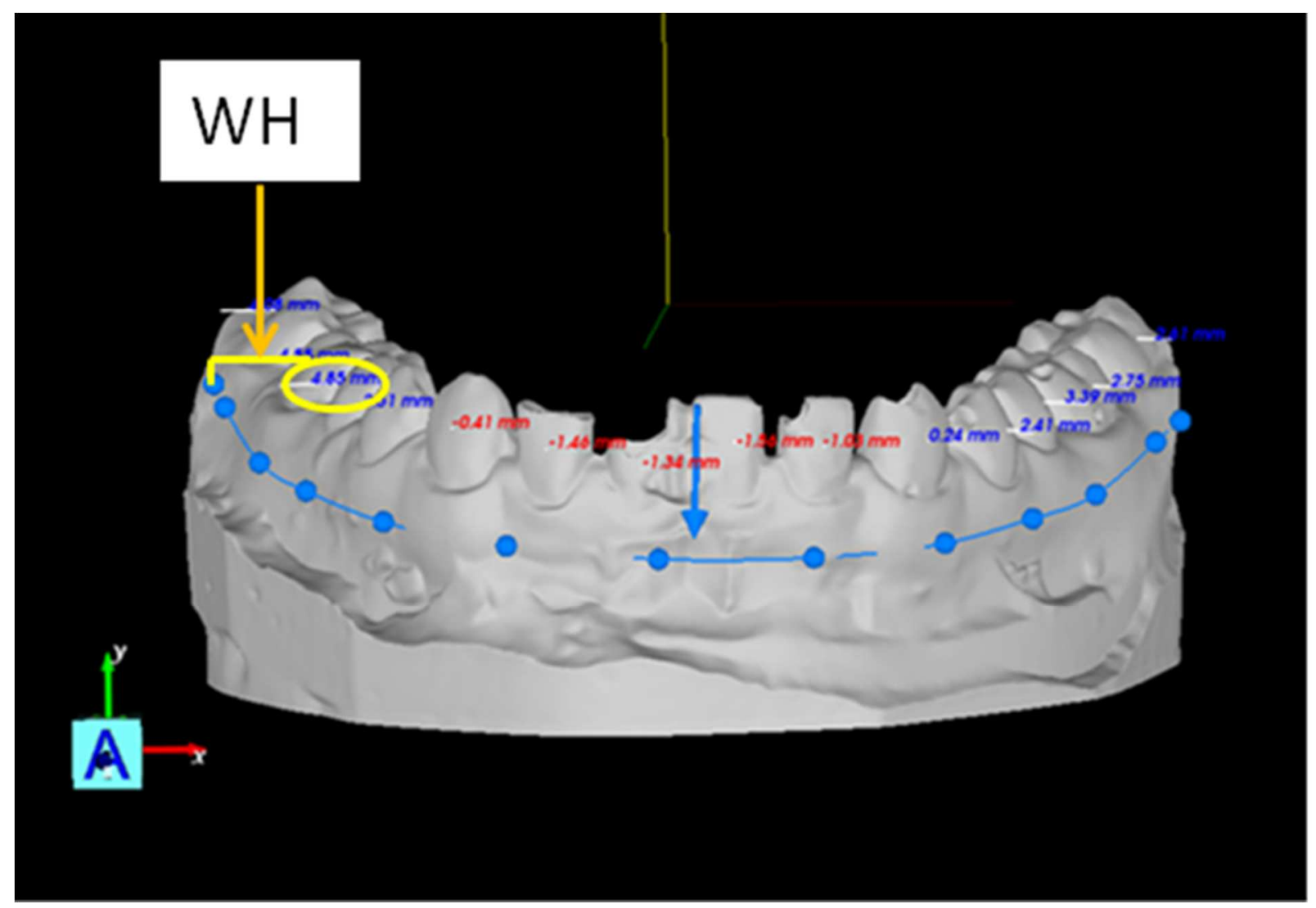

Figure 4: WALA ridge using the 6 Elements software

CBCT ANALYSIS

All de-identified dicom CBCT patient files were downloaded onto the Carestream 3D Imaging Software Version 3.5.7 for data collection. No calibration was necessary; CBCT images were already 1:1. See table 2 for data points and reference line descriptions. See table 3 for CBCT Variables. Each Posterior tooth type, second molar (M2), first molar (M1), second premolar (P2) and first premolars (P1) were evaluated as follows:

Table 2: DATA Points \& Reference Lines 


\begin{tabular}{|l|l|}
\hline Points & Description \\
\hline ROP & Reference Occlusal Plane \\
\hline CR & Center of Resistance \\
\hline ABC2 & $\begin{array}{l}\text { Alveolar Bone Center at level of Center of Resistance } \\
\text { Location }\end{array}$ \\
\hline ABC1 & Alveolar Bone Center at level of Apex Location \\
\hline APA & Apex Point Alveolar \\
\hline APB & Apex Point Basal Bone \\
\hline BBC & Basal Bone Center \\
\hline IBB & Most Inferior Basal Bone Border \\
\hline LAI & Tooth Long Axis Inclination (degrees) \\
\hline WV & WALA Vertical \\
\hline WH & WALA Horizontal \\
\hline
\end{tabular}

\section{Table 3: СВCT Variables}

\begin{tabular}{|l|l|}
\hline Variable & Definition \\
\hline D1 & Distance from $A B C 2$ to $C R$ \\
\hline D2 & Distance from ABC1 to APA \\
\hline D3 & Distance from BBC to APB \\
\hline D4 & Distance from WALA Vertical to CR \\
\hline LA & Angle measurement of tooth long axis at ROP \\
\hline
\end{tabular}

CONSTRUCTION OF REFERENCE OCCLUSAL PLANE \& LONG AXIS INCLINATION ANALYSIS

All measurements were made perpendicular or parallel to the ROP. The LAI provides information on the inclination of the tooth relative to the ROP. 


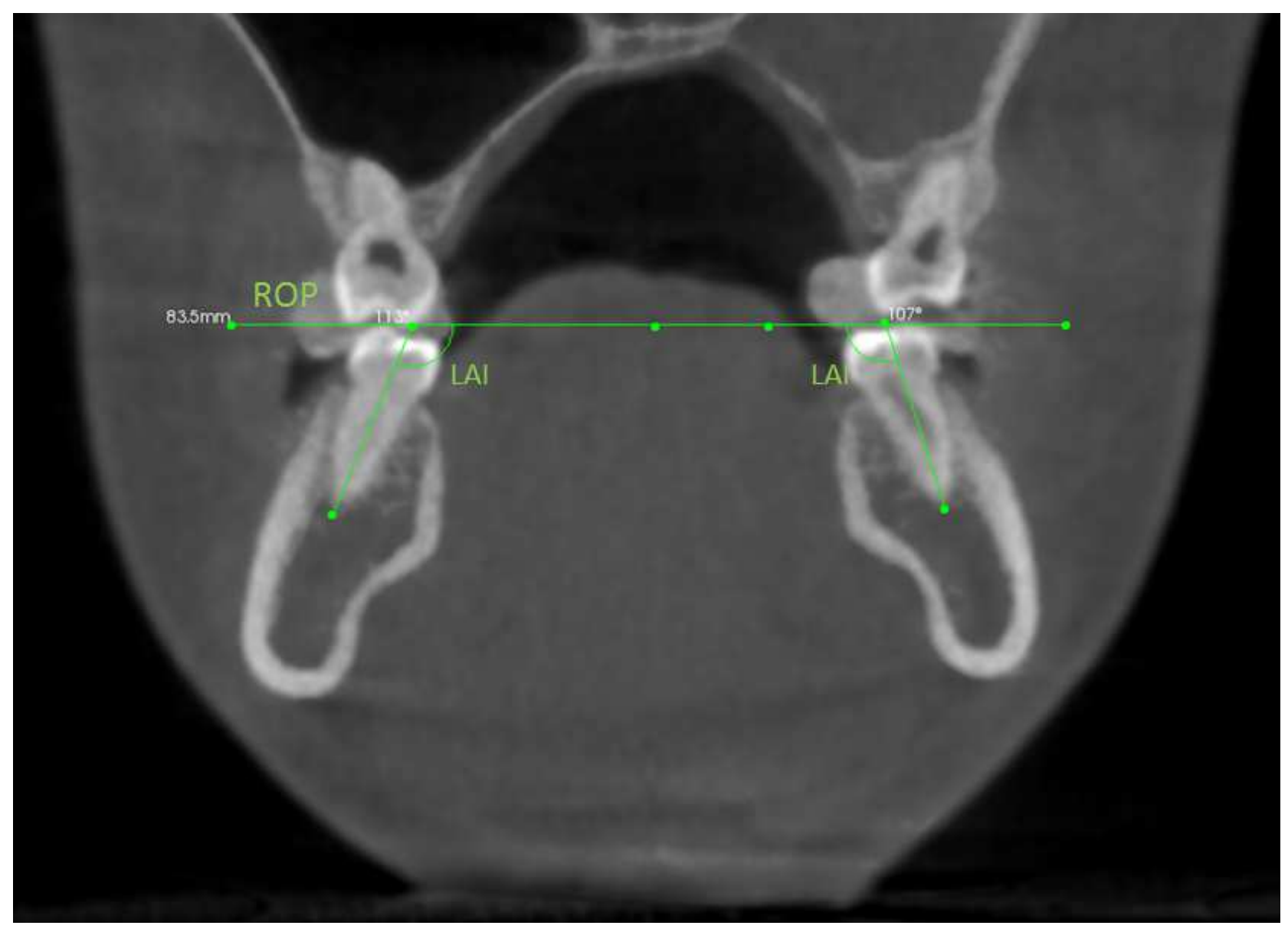

Figure 6: Example ROP and LAI

WALA VERTICAL TO CR ANALYSIS

The center of resistance was first measured from a sagittal view. Molars were measured from the top of the crown to the furcation area (Figure 7). Premolars were measured $1 / 3$ of the distance from the alveolar crest to the apex. Premolars were then measured from the top of 
the crown to CR point. CR and WALA Vertical measurements were transferred to the coronal view (figure 8). The distance of these two points was then measured and notated as D4.

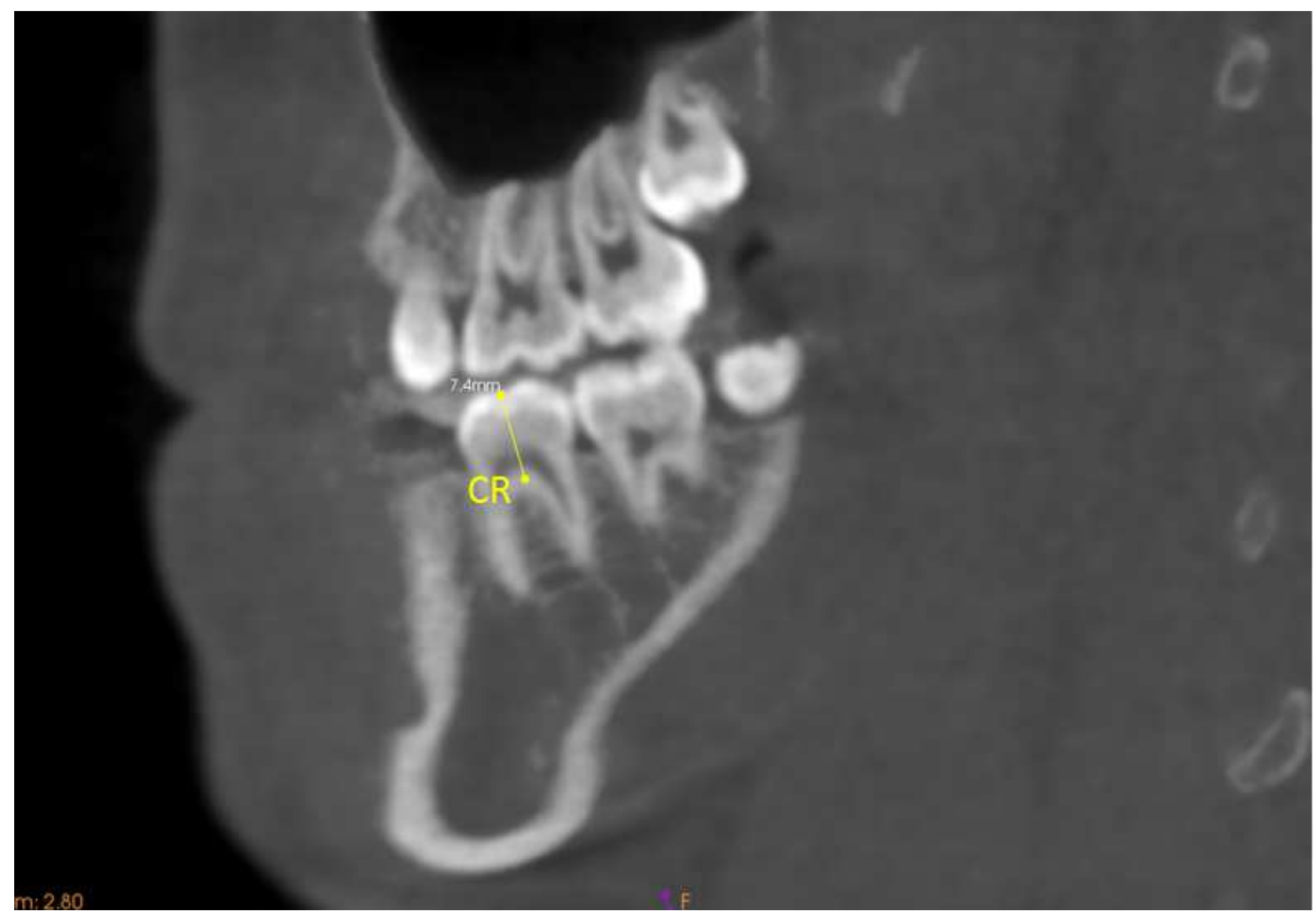

Figure 7: Measuring CR in sagittal view 


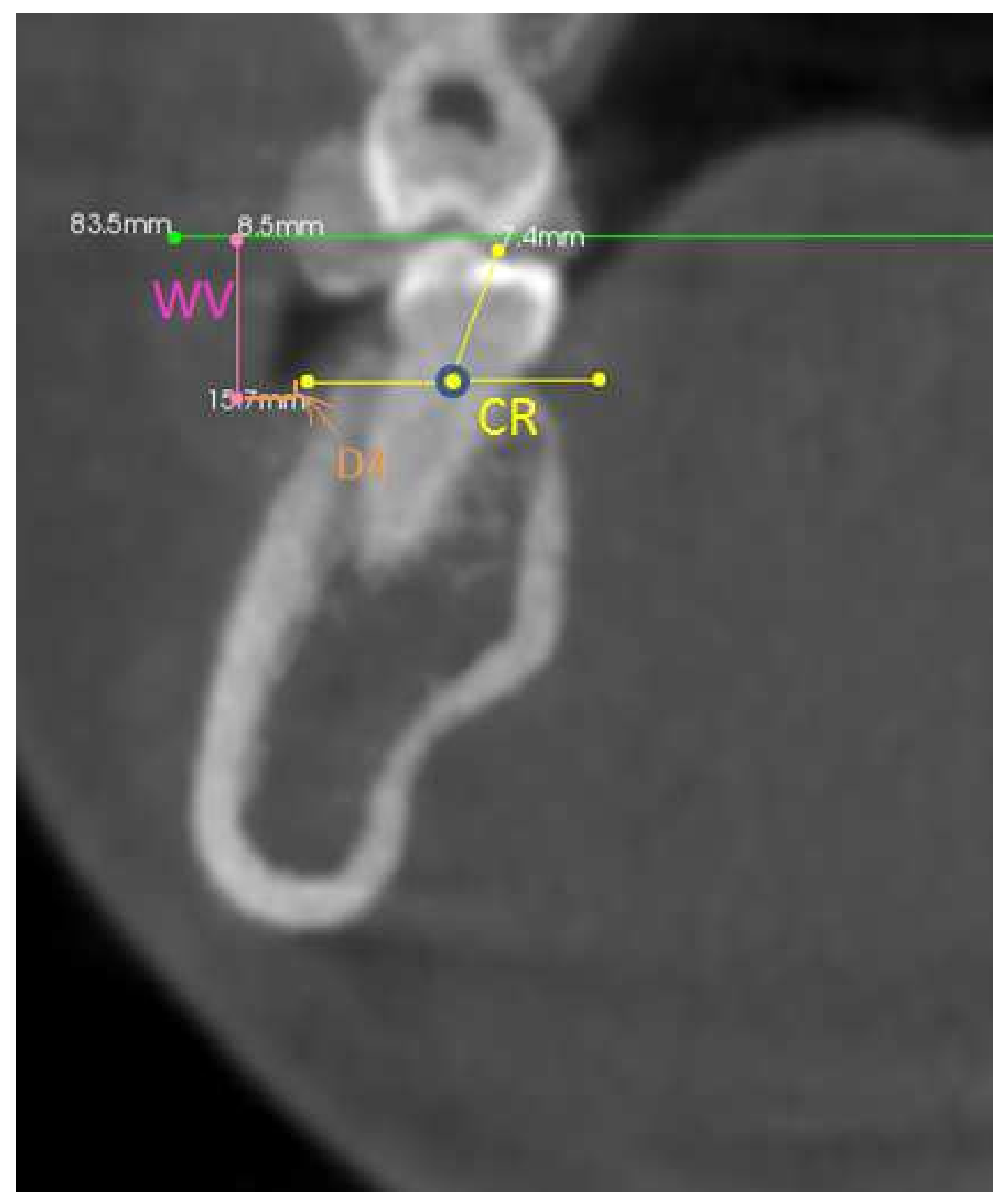

Figure 8: WALA Vertical \& Center of Resistance in the coronal view 
ALVEOLAR BONE ANALYSIS

Alveolar bone measurements were obtained at the center of resistance point (CR) and apex point alveolar (APA). The buccal lingual distance from the alveolar bone internal cortex was measured. This value was then divided in half to approximate the center of the alveolar bone at each location represented by $A B C 1$ and $A B C 2$. The distance of $C R$ and $A P A$ away from the alveolar center point was noted as D1 and D2 (Figure 9).

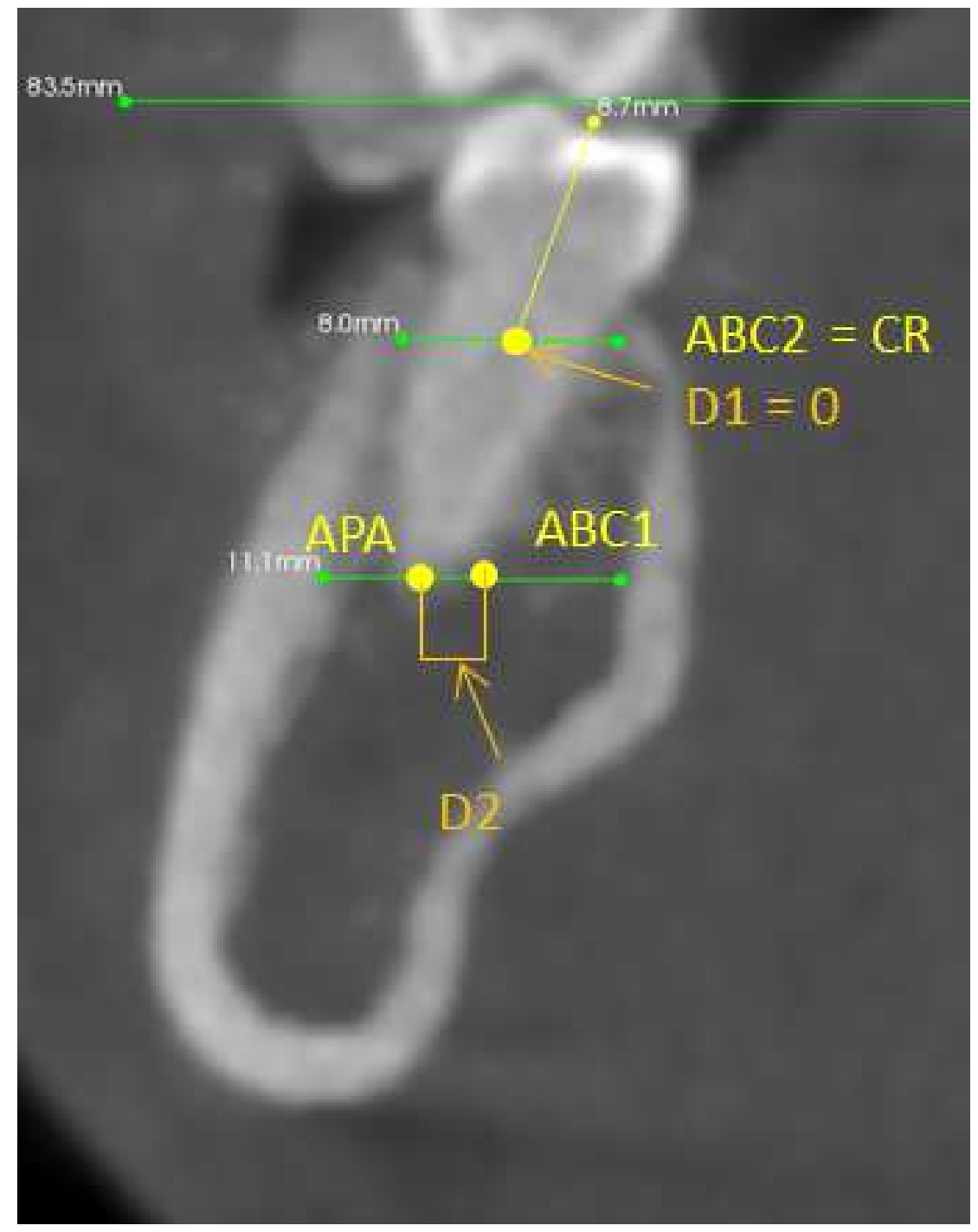

Figure 9: Alveolar bone measurements in the coronal view 
BASAL BONE ANALYSIS

Basal bone measurements were obtained at the basal bone center point (BBC) which was located vertically by taking half the distance from the tooth apex to the most inferior basal bone border (IBB). Once this vertical position was found, the buccal lingual distance from the basal bone internal cortex was measured. This value was then divided in half to approximate the center of the basal bone (BBC). The apex point basal bone (APB) was then constructed with a line from the tooth apex and perpendicular to the ROP to identify the apex location relative to the basal bone. The distance from BBC to APB was measured and noted as D3 (Figure 10).

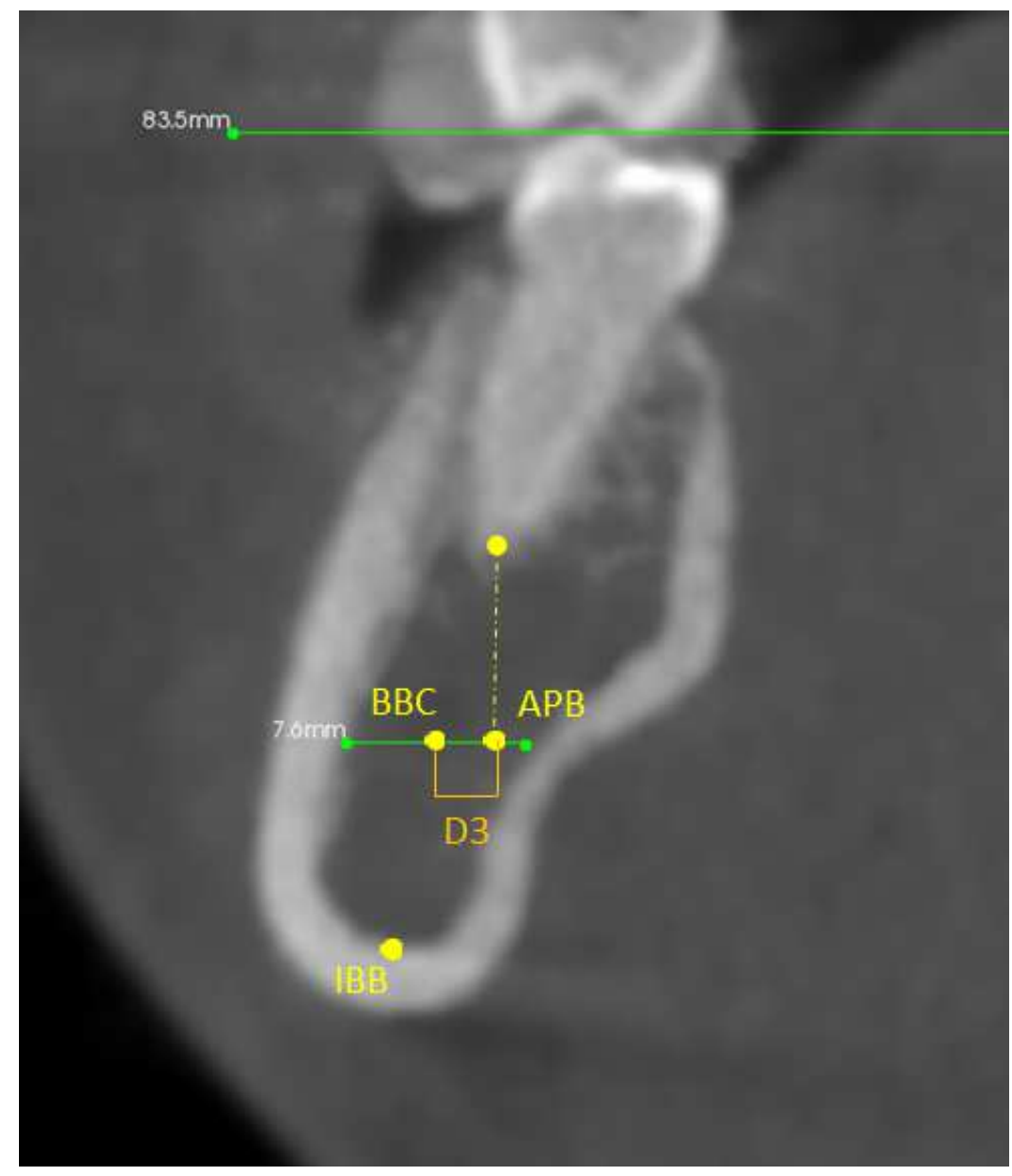

Figure 10: Basal bone measurements in the coronal view 


\section{STATISTICAL ANALYSIS}

The statistical analysis was carried about by the statistician (E.G.) using the JMP version 10 SAS Software. Descriptive statistics were performed to evaluate the mean, standard deviation, minimum, and maximum. Hypothesis of closeness for various variables studied were tested and the $p$-values calculated. Single linear regression analysis was performed to evaluate the relationship between both the long axis inclination and WALA ridge variables compared to the D1, D2, D3, variables.

\section{CHAPTER 4: RESULTS}

\section{DESCRIPTIVE STATISTICS}

Descriptive statistics were used to determine the mean, standard deviation, minimum and maximum and p-value for each of the variables. Tables $4 \& 5$ illustrate the results.

\section{Table 4: WALA Vertical to Center of Resistance}

\begin{tabular}{|c|r|r|r|r|r|r|}
\hline Variable & \multicolumn{1}{|c|}{ Mean } & \multicolumn{1}{c|}{ Std dev } & Std Err Mean & Upper 95\% Mean & Lower 95\% Mean & P-value \\
\hline P1-D4 & 1.25 & 0.811 & 0.139 & 1.533 & 0.966 & $<.0001$ \\
\hline P2-D4 & 1.68 & 0.753 & 0.129 & 1.948 & 1.422 & $<.0001$ \\
\hline M1-D4 & 0.86 & 0.646 & 0.11 & 1.09 & 0.639 & 0.0024 \\
\hline M2-D4 & 1.56 & 0.818 & 0.14 & 1.846 & 1.275 & $<.0001$ \\
\hline
\end{tabular}


Table5: Variables D1, D2, D3

\begin{tabular}{|c|r|r|r|r|r|r|}
\hline Variable & Mean & \multicolumn{1}{|c|}{ Std dev } & Std Err Mean & Upper 95\% Mean & Lower 95\% Mean & P-value \\
\hline P1-D1 & 0.511 & 0.545 & 0.093 & 0.702 & 0.321 & $<.001^{*}$ \\
\hline P1-D2 & 0.838 & 1.601 & 0.274 & 1.397 & 0.279 & $0.0045^{*}$ \\
\hline P1-D3 & 0.305 & 2.734 & 0.468 & 1.259 & -0.648 & 0.5187 \\
\hline P2-D1 & 0.411 & 0.664 & 0.113 & 0.643 & 0.18 & $0.001^{*}$ \\
\hline P2-D2 & -0.105 & 1.521 & 0.26 & 0.425 & -0.636 & 0.6875 \\
\hline P2-D3 & -1.423 & 1.985 & 0.3405 & -0.73 & -2.116 & $0.0002^{*}$ \\
\hline M1-D1 & 0.2147 & 0.4936 & 0.0846 & 0.3869 & 0.0424 & $0.0161^{*}$ \\
\hline M1-D2 & -0.294 & 1.94 & 0.332 & 0.382 & -0.971 & 0.383 \\
\hline M1-D3 & -1.997 & 2.02 & 0.347 & -1.29 & -2.7 & $<.0001^{*}$ \\
\hline M2-D1 & -0.638 & 0.993 & 0.17 & -0.291 & -0.984 & $0.0007^{*}$ \\
\hline M2-D2 & -1.626 & 1.574 & 0.2699 & -1.0771 & -2.175 & $<.0001^{*}$ \\
\hline M2-D3 & -3.35 & 1.88 & 0.324 & -2.69 & -4.01 & $<.0001^{*}$ \\
\hline
\end{tabular}

SINGLE LINEAR REGRESSION ANALYSIS

Single linear regression analysis was performed to evaluate the correlation between both the long axis inclination and WALA Ridge variables compared to the D1, D2, D3, variables. Long axis inclination and WALA Ridge Variables were also analyzed together for correlation. The following tables (6-12) illustrate the results within each specific category.

Table 6: Long Axis Inclination/Center of Resistance In Alveolar Bone

\begin{tabular}{|l|r|r|}
\hline \multicolumn{1}{|c|}{ Linear Fit } & R square & p-value for testing slope $=0$ \\
\hline P1-LAI /P1-D1 & 0.0614 & 0.157 \\
\hline P2-LAI /P2-D1 & 0.0153 & 0.485 \\
\hline M1-LAl/M1-D1 & 0.0007 & 0.88 \\
\hline M2-LAl/M2-D1 & 0.129 & $0.036^{*}$ \\
\hline
\end{tabular}


Table 7: Long Axis Inclination/Apex Point In Alveolar Bone

\begin{tabular}{|l|r|r|}
\hline \multicolumn{1}{|c|}{ Linear Fit } & \multicolumn{1}{|c|}{ R square } & p-value for testing slope = 0 \\
\hline P1-LAI /P1-D2 & 0.222 & $0.0049^{*}$ \\
\hline P2-LAI /P2-D2 & 0.051 & 0.1961 \\
\hline M1-LAI/M1-D2 & 0.0071 & 0.6334 \\
\hline M2-LAI/M2-D2 & 0.0083 & 0.6068 \\
\hline
\end{tabular}

Table 8: Long Axis Inclination/Apex Point Over Basal Bone

\begin{tabular}{|l|r|r|}
\hline \multicolumn{1}{|c|}{ Linear Fit } & \multicolumn{1}{|c|}{ R square } & p-value for testing slope $=0$ \\
\hline P1-LAI/P1-D3 & 0.116 & $0.0485^{*}$ \\
\hline P2-LAI/P2-D3 & 0.0661 & 0.1421 \\
\hline M1-LAI/M1-D3 & 0.0357 & 0.2842 \\
\hline M2-LAI/M2-D3 & 0.0086 & 0.6009 \\
\hline
\end{tabular}

Table 9: DWALA/Center of Resistance In Alveolar Bone

\begin{tabular}{|l|r|r|}
\hline \multicolumn{1}{|c|}{ Linear Fit } & R square & p-value for testing slope $=0$ \\
\hline P1-DWALA/P1-D1 & 0.0214 & 0.4091 \\
\hline P2-DWALA/P2-D1 & 0.0029 & 0.7609 \\
\hline M1-DWALA/M1-D1 & 0.0172 & 0.459 \\
\hline M2-DWALA/M2-D1 & 0.00229 & 0.7879 \\
\hline
\end{tabular}


Table 10: DWALA/Apex Point In Alveolar Bone

\begin{tabular}{|l|r|r|}
\hline \multicolumn{1}{|c|}{ Linear Fit } & R square & p-value for testing slope $=\mathbf{0}$ \\
\hline P1-DWALA/P1-D2 & 0.0108 & 0.5585 \\
\hline P2-DWALA/P2-D2 & 0.0001 & 0.9516 \\
\hline M1-DWALA/M1-D2 & 0.0375 & 0.2719 \\
\hline M2-DWALA/M2-D2 & 0.1852 & $0.0111^{*}$ \\
\hline
\end{tabular}

Table 11: DWALA/Apex Point Over Basal Bone

\begin{tabular}{|l|r|r|}
\hline \multicolumn{1}{|c|}{ Linear Fit } & R square & p-value for testing slope $=0$ \\
\hline P1-DWALA/P1-D3 & 0.0021 & 0.793 \\
\hline P2-DWALA/P2-D3 & 0.003 & 0.7578 \\
\hline M1-DWALA/M1-D3 & 0.0126 & 0.527 \\
\hline M2-DWALA/M2-D3 & 0.2403 & $.0032^{*}$ \\
\hline
\end{tabular}

Table 12: Long Axis Inclination/DWALA

\begin{tabular}{|l|r|r|}
\hline \multicolumn{1}{|c|}{ Linear Fit } & R square & p-value for testing slope $=0$ \\
\hline P1-LAI /P1-DWALA & 0.002 & 0.7985 \\
\hline P2-LAI /P2-DWALA & 0.123 & $0.0414^{*}$ \\
\hline M1-LAI/M1-DWALA & 0.461 & $<.0001^{*}$ \\
\hline M2-LAI/M2-DWALA & 0.067 & 0.1387 \\
\hline
\end{tabular}




\section{CHAPTER 5: DISCUSSION}

\section{WALA VERTICAL TO CENTER OF RESISTANCE ANALYSIS}

Andrews proposed the WALA Ridge in 2000 to serve as a primary landmark for assessing mandibular arch shape and providing a template for the maxillary transverse width. The WALA Ridge is a band of soft tissue immediately superior to the mandible's mucogingival junction and has been hypothesized to be at or nearly at the same vertical level as the center of rotation of the teeth in an arch. The WALA Vertical was measured to determine the location of the WALA Ridge in a vertical dimension compared to the location of each posterior tooth's center of resistance. The findings in this study reveal statistical significance ( $p$-value $<.05)$ that the center of resistance and WALA Ridge were located at or near each other for all mandibular posterior teeth (P1-D4), (P2-D4), (M1-D4), \& (M2-D4). This finding may suggest that the use of custom archwires may aid the clinician in establishing a proper tooth position by simple tipping mechanics.

\section{CENTER OF RESISTANCE POINT ANALYSIS}

Descriptive statistics where performed on each individual variable D1, D2, \& D3. However, because D2 and D3 variables evaluate the centeredness of the apex of posterior teeth at the level of the alveolar apex point and basal bone apex point only, with no relationship to the WALA ridge or long axis inclination, this information is not clinically applicable. Also the p-values for these variables do not have any consistent statistical significance with the values greatly scattered (table 5). 
On the other hand, D1 assessed the centeredness of the posterior teeth at the center of resistance point which has merit without including the WALA Ridge and long axis inclination. The findings in this study reveal statistical significance ( $p$-value $<.05)$ for all posterior teeth at the center of resistance level (P1-D1), (P2-D1), (M1-D1), \& (M2-D1). The finding in this sample suggests that the center of resistance is likely located in the center of the alveolar bone. Clinically this is important because if teeth are treated with a custom WALA archwire and tipped, then it can be hypothesized that they would at the least be centered in the alveolar bone.

LONG AXIS INCLINATION ANALYSIS AT D1, D2, \& D3

One of the goals when attempting to achieve a healthy functional occlusion is to have the occlusal forces directed down the long axis of the tooth. This is often accomplished by uprighting molar teeth so that the occlusal tables are level. Premolars differ from molars in the fact that the anatomy of the occlusal table makes it hard to standardize a level table. For this reason the long axis inclination was used instead of the occlusal table inclination in order to better standardize the measurements between molar and premolar teeth.

Long axis inclination was determined for each posterior tooth and single linear regression was performed to determine correlation at variables D1, D2, D3. At the level of the center of resistance (D1) there was only correlation at the second molar (M2) with a p-value of 0.036. The apex point alveolar (D2) showed correlation at the first premolar (P1) with a p-value of 0.0049 , however no other teeth at this level in the bone showed correlation with statistical significance. At the level of the basal bone (D3) there was again correlation with the first 
premolar (P1) with a p-value of 0.0485 . The second premolar (P2), first molar (M1), and second molar (M2) showed no correlation with statistical significance. It should also be noted that although the first premolar (P1) showed statistical significance it closely approached the cut off for significance.

DWALA ANALYSIS AT D1, D2, \& D3

The WALA Ridge is a bridge between a clinician's goal in theory and actual clinical execution. When teeth are treated to this landmark it has been proposed that teeth will have been tipped to their proper position and centered over basal bone. This linear regression analysis assessed the validity of this idea by evaluating posterior teeth as they approach the WALA Ridge (DWALA) and correlating their relationship to the variables D1, D2, and D3. DWALA shows no correlation for any posterior teeth at the center of resistance location (D1). At apex point alveolar the second molar (M2) has statistical significance with a p-value of 0.0111. P1, P2, and M1 show no correlation. At the level of the basal bone the second molar (M2) has statistical significance with a p-value of 0.032 . P1, P2, and M1 show no correlation. These results showed to be inconsistent and with no statistical significance for all posterior teeth studied.

\section{LONG AXIS INCLINATION \& DWALA ANALYSIS}

Linear regression analysis was performed to evaluate the correlation for the long axis inclination and DWALA. In theory as a tooth is more upright it would approach the WALA ridge norms. Statistical significance ( $p$-value $<.05$ ) was found for the second premolar $(P 2)$ and first molar (M1). P2 had a p-value of $0.0414 . \mathrm{M} 1$ had a $\mathrm{p}$-value of $<.0001$ showing very strong 
correlation. There was no correlation found for the first premolar (P1) or second molar (M2).

P1 had a p-value of 0.7985 and M2 with a p-value of 0.1387 . These results showed to be inconsistent and with no statistical significance across the board.

\section{CHAPTER 6: SUMMARY \& CONCLUSIONS}

SUMMARY

The objectives of this study included:

1. To investigate if the roots of more optimally inclined teeth as defined by the long axis inclination and WALA Ridge are more centered over basal bone.

2. To investigate if the roots of more optimally inclined teeth as defined by the long axis inclination and WALA Ridge are more centered in alveolar bone.

3. To investigate if the estimated center of resistance point is most often centered in alveolar bone, validating the need to simply tip teeth to their ideal position.

4. To investigate if the current concept of "centeredness over basal bone" is a misnomer and the term alveolar arch or ridge is a more accurate description due to its clinical application and the fact that the alveolar process is the investing structure of the teeth.

5. To investigate if the WALA ridge is located at or near the estimated center of resistance of molar and premolar teeth.

The following null hypotheses were rejected:

1. The WALA ridge soft tissue landmark is not located at or near the center of resistance of premolar and molar teeth.

2. The center of resistance point is most often not centered in the alveolar bone. 
The following null hypotheses were accepted:

1. The root apices of teeth with FA points more optimally related to the WALA Ridge are not more centered over basal bone.

2. The center of resistance of teeth with FA points more optimally related to the WALA Ridge are not more centered in alveolar bone.

3. The root apices of teeth with FA points more optimally related to the WALA Ridge are not more centered in alveolar bone.

4. The root apices of more upright posterior teeth based on the long axis inclination are not more centered over basal bone.

5. The center of resistance of more upright posterior teeth based on the long axis inclination are not more centered in alveolar bone.

6. The root apices of more upright posterior teeth based on the long axis inclination are not more centered in alveolar bone.

7. The FA point of more upright posterior teeth based on long axis inclination are not more related to the WALA Ridge per Andrews' Element 1.

\section{CONCLUSIONS}

The results of this study lead to the following conclusions:

1. The WALA Ridge soft tissue landmark is located at or near the center of resistance for all posterior teeth.

2. The center of resistance of all posterior teeth can most often be found in the center of the alveolar bone.

3. Teeth more closely related to the WALA ridge landmark are not more centered over basal bone. 
4. Teeth more closely related to the WALA ridge landmark are not more centered in alveolar bone.

5. More upright posterior teeth based on long axis inclination are not more centered over basal bone.

6. More upright posterior teeth based on long axis inclination are not more centered in alveolar bone.

7. The FA point of more upright posterior teeth based on long axis inclination are not more related to the WALA Ridge per Andrews' Element 1.

\section{CHAPTER 7: SUGGESTIONS FOR FUTURE RESEARCH}

The following areas could be evaluated:

1. Orthodontic research sample could be evaluated with pre and post CBCT images of patients treated with custom WALA archwires to assess tooth position in alveolar bone and over basal bone.

2. Due to the fact that this was a pilot study, continued data could be collected and analyzed to increase the sample size to see if any new conclusions could be found. Also the data could be collected by more than one person.

3. The same study could be conducted evaluating mandibular anterior teeth. 


\section{WORKS CITED}

1. Bell GD. THREE-DIMENSIONAL CONE BEAM COMPUTERIZED TOMOGRAPHY ASSESSMENT OF BASAL BONE PARAMETERS AND CROWDING. 2008.

2. Tweed C. <br / >A philosophy of orthodontic treatment. Am J of Orthod and Oral Surg. 1945;31:74103.

3. Daskalogiannakis J. Glossary of orthodontic terms. American Journal of Orthodontics and Dentofacial Orthopedics. 2002;122(3):335-335.

4. Andrews LF. The six keys to normal occlusion. Am J Orthod. 1972;62(3):296-309.

5. Salzmann JA. Orthodontic therapy as limited by ontogenetic growth and the basal arches. Am J Orthod. ;34(4):297-319. doi: 10.1016/0002-9416(48)90029-3.

6. Brodie AG. Appraisal of present concepts in Orthodontia1. Angle Orthod. 1950;20(1):24-38.

7. Vanarsdall RL, Secchi AG, Chung C, Katz SH. Mandibular basal structure response to lip bumper treatment in the transverse dimension. Angle Orthod. 2004;74(4):473-479.

8. Kanaan W. The Correlation Between Tooth Size-basal Bone Size Discrepancy and Long Term Stability of the Lower Incisors in Class II Division 1 Patients. 2006.

9. SCHULHOF RJ, LESTREL PE, WALTERS R, SCHULER R. The mandibular dental arch: Part III buccal expansion. Angle Orthod. 1978;48(4):303-310.

10. Angle EH. Treatment of malocclusion of the teeth: Angle's system. White Dental Manufacturing Company; 1907.

11. Frãßnkel R. Decrowding during eruption under the screening influence of vestibular shields. Am J Orthod. ;65(4):372-406.

12. Moss ML, Salentijn L. The primary role of functional matrices in facial growth. Am J Orthod. ;55(6):566-577.

13. Damon D. Treatment of the face with biocompatible orthodontics. Orthodontics: Current Principles and Techniques.Saint Louis, MO, Elsevier. 2005:753-831.

14. Peck S. So what's new? arch expansion, again. Angle Orthod. 2008;78(3):574-575.

15. Lundström AF. Malocclusion of the teeth regarded as a problem in connection with the apical base. International Journal of Orthodontia, Oral Surgery and Radiography. 1925;11(9):793-812.

16. Strang RHW. The fallacy of denture expansion as a treatment procedure*. Angle Orthod. 1949;19(1):12-22. 
17. Howes A. Expansion as a treatment procedureâ€"Where does it stand today? Am J Orthod. ;46(7):515-534.

18. Sergl HG, Kerr WJS, McColl JH. A method of measuring the apical base. The European Journal of Orthodontics. 1996;18(5):479-483. doi: 10.1093/ejo/18.5.479.

19. Downs WB. Variations in facial relationships: Their significance in treatment and prognosis. Am J Orthod. ;34(10):812-840.

20. Howes AE. Case analysis and treatment planning based upon the relationship of the tooth material to its supporting bone. American Journal of Orthodontics and Oral Surgery. 1947;33(8):499-533.

21. Rees DJ. A method for assessing the proportional relation of apical bases and contact diameters of the teeth. Am J Orthod. ;39(9):695-707.

22. Falck F. Comparative studies on the development of the tooth root following orthodontic treatment with the active plate and function regulator. Fortschr Kieferorthop. 1969;30(2):225-229.

23. Miethke RR, Lindenau S, Dietrich K. The effect of frankel's function regulator type III on the apical base. Eur J Orthod. 2003;25(3):311-318.

24. Weaver KE, Tremont TJ, Ngan P, et al. Changes in dental and basal archforms with preformed and customized archwires during orthodontic treatment. Orthodontic Waves. 2012;71(2):45-50.

25. Triviño T, Siqueira DF, Andrews WA. Evaluation of distances between the mandibular teeth and the alveolar process in brazilians with normal occlusion. American Journal of Orthodontics and Dentofacial Orthopedics. 2010;137(3):308.e1-308.e4.

26. Ball RL, Miner RM, Will LA, Arai K. Comparison of dental and apical base arch forms in class II division 1 and class I malocclusions. American Journal of Orthodontics and Dentofacial Orthopedics. 2010;138(1):41-50.

27. Ronay V, Miner RM, Will LA, Arai K. Mandibular arch form: The relationship between dental and basal anatomy. American Journal of Orthodontics and Dentofacial Orthopedics. 2008;134(3):430-438.

28. Sodek J, Mckee MD. Molecular and cellular biology of alveolar bone. Periodontol 2000. 2000;24(1):99-126.

29. Kapila S. Cone beam computed tomography in orthodontics: Indications, insights, and innovations. Wiley Online Library; 2014.

30. Cattaneo P, Treccani M, Carlsson K, et al. Transversal maxillary dento-alveolar changes in patients treated with active and passive self-ligating brackets: A randomized clinical trial using CBCT-scans and digital models. Orthodontics \& Craniofacial Research. 2011;14(4):222-233.

31. Fleming PS, DiBiase AT, Lee RT. Self-ligating appliances: Evolution or revolution. Aust Orthod J. 2008;24:41-49. 
32. Damon DH. The rationale, evolution and clinical application of the self-ligating bracket. Clin Orthod Res. 1998;1(1):52-61.

33. Damon DH. The damon low-friction bracket: A biologically compatible straight-wire system. J Clin Orthod. 1998;32(11):670-680.

34. Girardot A, Jr., ed. Goal-directed orthodontics. ; 2013.

35. Koke U, Sander C, Heinecke A, Muller HP. A possible influence of gingival dimensions on attachment loss and gingival recession following placement of artificial crowns. Int J Periodontics Restorative Dent. 2003;23(5):439-445.

36. Richman C. Is gingival recession a consequence of an orthodontic tooth size and/or tooth position discrepancy?" A paradigm shift. Compend Contin Educ Dent. 2011;32(1):62-69.

37. Watson WG. Expansion and fenestration or dehiscence. Am J Orthod. 1980;77(3):330-332.

38. Yagci A, Veli I, Uysal T, Ucar FI, Ozer T, Enhos S. Dehiscence and fenestration in skeletal class I, II, and III malocclusions assessed with cone-beam computed tomography. Angle Orthod. 2012;82(1):67-74.

39. Andlin-Sobocki A, Bodin L. Dimensional alterations of the gingiva related to changes of facial/lingual tooth position in permanent anterior teeth of children. J Clin Periodontol. 1993;20(3):219-224.

40. Coatoam GW, Behrents RG, Bissada NF. The width of keratinized gingiva during orthodontic treatment: Its significance and impact on periodontal status*. J Periodontol. 1981;52(6):307-313.

41. Engelking G, Zachrisson BU. Effects of incisor repositioning on monkey periodontium after expansion through the cortical plate. Am J Orthod. 1982;82(1):23-32.

42. Wennström JL, Lindhe J, Sinclair F, Thilander B. Some periodontal tissue reactions to orthodontic tooth movement in monkeys. J Clin Periodontol. 1987;14(3):121-129.

43. Garib DG, Yatabe MS, Ozawa TO, Silva Filho, Omar Gabriel da. Alveolar bone morphology under the perspective of the computed tomography: Defining the biological limits of tooth movement. Dental Press Journal of Orthodontics. 2010;15(5):192-205.

44. Sukovic $P$, Brooks S, Perez L, Clinthorne N. DentoCAT ${ }^{\mathrm{TM}}$-a novel design of a cone-beam CT scanner for dentomaxillofacial imaging: Introduction and preliminary results. . 2001;1230:700-705.

45. Larry Andrews WA. Syllabus of the andrews orthodontic philosophy. 2013. 


\section{WestVurginiaUniversity}

Omce ef Rescarch Interrity and Compliance

Acknowledgement Letter Exempt Initial Protocol Review

\begin{tabular}{|c|c|}
\hline Acthe Dute & 6612:3015 \\
\hline Te & Timely Trement \\
\hline Free- & WVU OMke ef Resendh lesegrity and Cenoliance \\
\hline Apereval Date & 6612:2015 \\
\hline Evpiraties Date & 6ovitais \\
\hline Sebjest & 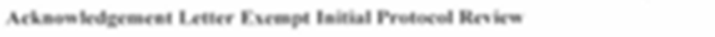 \\
\hline Proteced Nember & 1506706405 \\
\hline Tive & 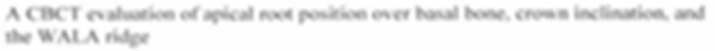 \\
\hline
\end{tabular}

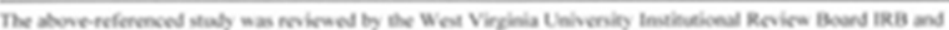

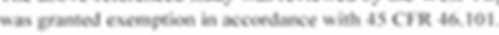

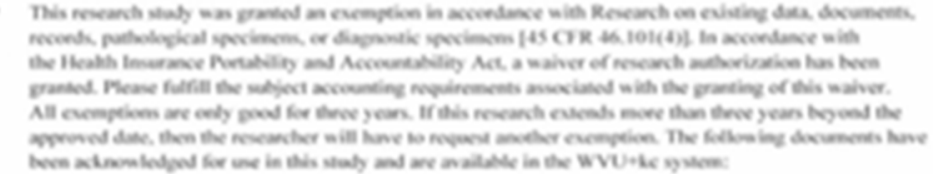

Doxuments for use in this gludy have been acknowlebged and ave avallate in the wrvac gylem in the Notes and Altachinents section of your protocel.

Me Office of Research inteyling and Conpliance is here to provile assistance so you froen the inkilal subenibsion

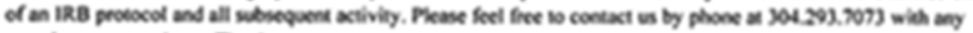
guestion you may have. Thank you.

wrv Omike of Research Inecyily ans Cempliance

Dete Q6122015

Signed:

Anfton Wagner

Afton Wagner

IRB Administrator 


\section{Letter of Permission to Conduct Research}

I, Carl P. Roy D.D.S., M.S., give my permission for Timothy R. Glass D.D.S. to conduct his study entitled A CBCT Evaluation of Apical Root Position Over Basal Bone, Crown Inclination, and the WALA Ridge at Roy Orthodontics located at 4388 Holland Rd., Ste. 200, Virginia Beach, VA 23452.

Signaturg of Location Administrator

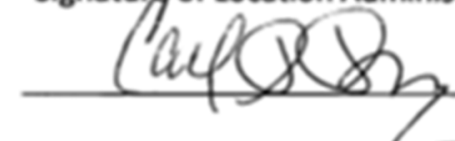

Printed Location Administrator Name

Carl P. Roy

Date

$6 / 3 / 2015$ 
APPENDIX (C)- DATA

\section{Cast Data}

\begin{tabular}{|c|c|c|c|c|c|c|c|}
\hline & & \multicolumn{3}{|c|}{ First Premolar (P1) } & \multicolumn{3}{|c|}{ Second Premolar (P2) } \\
\hline \multicolumn{2}{|c|}{ Cast Number } & DWALA & WALA Horizontal & WALA Vertical & DWALA & WALA Horizontal & WALA Vertical \\
\hline \multirow[t]{2}{*}{1} & Right & 0.82 & 1.62 & 9.81 & 1.78 & 3.08 & 8.33 \\
\hline & Left & -0.44 & 0.36 & 9.6 & 0.9 & 2.2 & 8.56 \\
\hline \multirow[t]{2}{*}{2} & Right & 1.68 & 2.48 & 9.93 & 0.98 & 2.28 & 8.55 \\
\hline & Left & 2.07 & 2.87 & 9.82 & 1.96 & 3.26 & 8.9 \\
\hline \multirow[t]{2}{*}{3} & Right & 0.1 & 0.9 & 9.93 & -0.09 & 1.21 & 9.36 \\
\hline & Left & -0.04 & 0.76 & 9.94 & -0.13 & 1.17 & 9.88 \\
\hline \multirow[t]{2}{*}{4} & Right & 1.12 & 1.92 & 9.75 & 1.71 & 3.01 & 8.77 \\
\hline & Left & 0.82 & 1.62 & 9.58 & -0.08 & 1.22 & 9.46 \\
\hline \multirow[t]{2}{*}{5} & Right & 0.02 & 0.82 & 10.18 & -0.07 & 1.23 & 9.76 \\
\hline & Left & 0.33 & 1.13 & 10.01 & 0.45 & 1.75 & 9.66 \\
\hline \multirow[t]{2}{*}{6} & Right & 0.49 & 1.29 & 9.74 & -0.02 & 1.28 & 9.58 \\
\hline & Left & 0.84 & 1.64 & 9.56 & 1.07 & 2.37 & 8.77 \\
\hline \multirow[t]{2}{*}{7} & Right & 0.42 & 1.22 & 11.52 & 1.68 & 2.98 & 9.79 \\
\hline & Left & -0.41 & 0.39 & 10.44 & 0.64 & 1.94 & 9.48 \\
\hline \multirow[t]{2}{*}{8} & Right & -0.42 & 0.38 & 10.26 & 0.05 & 1.35 & 9.63 \\
\hline & Left & 0.83 & 1.63 & 10.2 & 0.24 & 1.54 & 9.51 \\
\hline \multirow[t]{2}{*}{9} & Right & 1 & 1.8 & 10.67 & 1.5 & 2.8 & 10.05 \\
\hline & Left & 0.73 & 1.53 & 11.4 & 0.79 & 2.09 & 10.1 \\
\hline \multirow[t]{2}{*}{10} & Right & -0.01 & 0.79 & 10.3 & 0.45 & 1.75 & 9.73 \\
\hline & Left & 0.33 & 1.13 & 10.95 & 1.12 & 2.42 & 9.78 \\
\hline \multirow[t]{2}{*}{11} & Right & 0.57 & 1.37 & 11.04 & 0.28 & 1.58 & 9.67 \\
\hline & Left & -0.03 & 0.77 & 10.68 & -0.76 & 0.54 & 9.7 \\
\hline \multirow[t]{2}{*}{12} & Right & 1.2 & 2 & 9.84 & 1.19 & 2.49 & 9.44 \\
\hline & Left & 0.69 & 1.49 & 10.63 & 0.8 & 2.1 & 9.88 \\
\hline \multirow[t]{2}{*}{13} & Right & -0.08 & 0.72 & 10.03 & 0.53 & 1.83 & 9.18 \\
\hline & Left & 0.63 & 1.43 & 10.25 & 0.51 & 1.81 & 9 \\
\hline \multirow[t]{2}{*}{14} & Right & -0.23 & 0.57 & 10.49 & -0.28 & 1.02 & 10.07 \\
\hline & Left & 0.56 & 1.36 & 11.44 & 0.6 & 1.9 & 10.38 \\
\hline \multirow[t]{2}{*}{32} & Right & 0.94 & 1.74 & 9.9 & 0.82 & 2.12 & 9.51 \\
\hline & Left & 0.22 & 1.02 & 9.58 & 0.38 & 1.68 & 8.94 \\
\hline \multirow[t]{2}{*}{41} & Right & 0.66 & 1.46 & 10.38 & 1.31 & 2.61 & 9.91 \\
\hline & Left & 1.15 & 1.95 & 10.09 & 1.16 & 2.46 & 9.58 \\
\hline \multirow[t]{2}{*}{50} & Right & 0.28 & 1.08 & 9.65 & 0.93 & 2.23 & 8.99 \\
\hline & Left & 0.43 & 1.23 & 10.54 & 0.96 & 2.26 & 10.13 \\
\hline
\end{tabular}




\begin{tabular}{|c|c|c|c|c|c|c|c|}
\hline & & \multicolumn{3}{|c|}{ First Molar (M1) } & \multicolumn{3}{|c|}{ Second Molar (M2) } \\
\hline \multicolumn{2}{|c|}{ Cast Number } & DWALA & WALA Horizontal & WALA Vertical & DWALA & WALA Horizontal & WALA Vertical \\
\hline \multirow[t]{2}{*}{1} & Right & 1.93 & 3.93 & 7.4 & 1.82 & 4.02 & 7.21 \\
\hline & Left & 0.3 & 2.3 & 7.36 & 0.34 & 2.54 & 6.7 \\
\hline \multirow[t]{2}{*}{2} & Right & 0.63 & 2.63 & 8.47 & 0.37 & 2.57 & 8.14 \\
\hline & Left & 1.37 & 3.37 & 8.55 & -0.76 & 1.44 & 7.71 \\
\hline \multirow[t]{2}{*}{3} & Right & 0.34 & 2.34 & 8.83 & 0.59 & 2.79 & 8.6 \\
\hline & Left & 0.89 & 2.89 & 8.66 & 1.39 & 3.59 & 7.18 \\
\hline \multirow[t]{2}{*}{4} & Right & 1.34 & 3.34 & 8.42 & 1.05 & 3.25 & 6.26 \\
\hline & Left & -0.63 & 1.37 & 8.29 & 2.11 & 4.31 & 6.36 \\
\hline \multirow[t]{2}{*}{5} & Right & 0.17 & 2.17 & 8.26 & 0.05 & 2.25 & 7.96 \\
\hline & Left & 0.04 & 2.04 & 8.31 & 0.83 & 3.03 & 8.39 \\
\hline \multirow[t]{2}{*}{6} & Right & 0.34 & 2.34 & 8.12 & 1.14 & 3.34 & 7.51 \\
\hline & Left & 0.48 & 2.48 & 7.95 & 1.1 & 3.3 & 6.21 \\
\hline \multirow[t]{2}{*}{7} & Right & 0.09 & 2.09 & 9.59 & 0.46 & 2.66 & 7.21 \\
\hline & Left & -0.08 & 1.92 & 9.4 & 1.55 & 3.75 & 6.72 \\
\hline \multirow[t]{2}{*}{8} & Right & 0.55 & 2.55 & 9.03 & 1.58 & 3.78 & 7.37 \\
\hline & Left & 0.32 & 2.32 & 9.43 & 1.08 & 3.28 & 7.58 \\
\hline \multirow[t]{2}{*}{9} & Right & 1.42 & 3.42 & 10 & 0.8 & 3 & 9 \\
\hline & Left & 0.81 & 2.81 & 9.14 & 1.28 & 3.48 & 8.2 \\
\hline \multirow[t]{2}{*}{10} & Right & 0.54 & 2.54 & 9.18 & 1.05 & 3.25 & 7.84 \\
\hline & Left & 1.19 & 3.19 & 8.79 & 1.56 & 3.76 & 7.64 \\
\hline \multirow[t]{2}{*}{11} & Right & 0.52 & 2.52 & 9.21 & 0.47 & 2.67 & 7.82 \\
\hline & Left & -0.46 & 1.54 & 9.06 & 0.73 & 2.93 & 7.67 \\
\hline \multirow[t]{2}{*}{12} & Right & 1.46 & 3.46 & 8.45 & 1.62 & 3.82 & 7.17 \\
\hline & Left & 1.34 & 3.34 & 8.95 & 1.92 & 4.12 & 6.88 \\
\hline \multirow[t]{2}{*}{13} & Right & 1.43 & 3.43 & 8.08 & 0.42 & 2.62 & 6.2 \\
\hline & Left & 0.82 & 2.82 & 7.28 & 0.94 & 3.14 & 6.76 \\
\hline \multirow[t]{2}{*}{14} & Right & 0.11 & 2.11 & 9.49 & 1 & 3.2 & 9.01 \\
\hline & Left & 0.35 & 2.35 & 9.95 & 0.22 & 2.42 & 9.19 \\
\hline \multirow[t]{2}{*}{32} & Right & 1.4 & 3.4 & 8.84 & 1.66 & 3.86 & 8.21 \\
\hline & Left & 1.26 & 3.26 & 7.7 & 1.72 & 3.92 & 7.28 \\
\hline \multirow[t]{2}{*}{41} & Right & 1.15 & 3.15 & 9.5 & 1.41 & 3.61 & 6.99 \\
\hline & Left & 1.21 & 3.21 & 9.15 & 2.12 & 4.32 & 6.39 \\
\hline \multirow[t]{2}{*}{50} & Right & 0.36 & 2.36 & 8.69 & 1.19 & 3.39 & 6.93 \\
\hline & Left & 0.49 & 2.49 & 7.91 & 0.58 & 2.78 & 6.82 \\
\hline
\end{tabular}


CBCT Data

\begin{tabular}{|c|c|c|c|c|c|c|c|}
\hline & & \multicolumn{6}{|c|}{ First Premolar (P1) } \\
\hline \multicolumn{2}{|c|}{ Cast Number } & D3 & D1 & $\mathrm{D} 2$ & D4 & DWALA & LAI (Degrees) \\
\hline \multirow[t]{2}{*}{1} & Right & 4 & 0 & 3 & 1.4 & 0.82 & 91 \\
\hline & Left & 1.7 & 0.5 & 2.7 & 1.4 & -0.44 & 87 \\
\hline \multirow[t]{2}{*}{2} & Right & -0.8 & 0 & -0.9 & 0.1 & 1.68 & 69 \\
\hline & Left & 0 & 1.4 & 2.7 & 0.7 & 2.07 & 88 \\
\hline \multirow[t]{2}{*}{3} & Right & 0.3 & -0.3 & 0.6 & 0.5 & 0.1 & 79 \\
\hline & Left & 0.6 & 0.5 & 0.4 & 2.1 & -0.04 & 88 \\
\hline \multirow[t]{2}{*}{4} & Right & -1.6 & 1.1 & -0.5 & 3.1 & 1.12 & 95 \\
\hline & Left & -0.7 & 1.3 & 0.9 & 2.4 & 0.82 & 87 \\
\hline \multirow[t]{2}{*}{5} & Right & -1.1 & -0.3 & 0 & 0.7 & 0.02 & 85 \\
\hline & Left & -0.2 & 0.5 & 1 & 1.9 & 0.33 & 91 \\
\hline \multirow[t]{2}{*}{6} & Right & -0.4 & -0.5 & -0.4 & 0.7 & 0.49 & 80 \\
\hline & Left & 0.9 & 0.6 & 1.8 & 2.6 & 0.84 & 82 \\
\hline \multirow[t]{2}{*}{7} & Right & -2.3 & -0.2 & -0.4 & 1 & 0.42 & 84 \\
\hline & Left & -1.6 & 0.3 & -0.9 & 2.3 & -0.41 & 83 \\
\hline \multirow[t]{2}{*}{8} & Right & -2.1 & 0.4 & -0.2 & 1.6 & -0.42 & 79 \\
\hline & Left & -4.3 & 1.3 & -1.9 & 1.3 & 0.83 & 76 \\
\hline \multirow[t]{2}{*}{9} & Right & -0.8 & 0.4 & 1.3 & 1.4 & 1 & 90 \\
\hline & Left & 1.2 & 1.1 & 0.8 & 0.5 & 0.73 & 88 \\
\hline \multirow[t]{2}{*}{10} & Right & 4.2 & 0.8 & 4.3 & 0.3 & -0.01 & 90 \\
\hline & Left & -1 & 0 & 0.5 & 0.8 & 0.33 & 81 \\
\hline \multirow[t]{2}{*}{11} & Right & 3.6 & 0 & 1.7 & 0.7 & 0.57 & 89 \\
\hline & Left & 6 & 0.8 & 2.6 & 0.9 & -0.03 & 81 \\
\hline \multirow[t]{2}{*}{12} & Right & 0.2 & 0.4 & 0.9 & 2.4 & 1.2 & 89 \\
\hline & Left & -0.1 & 0.4 & 0.3 & 0.4 & 0.69 & 85 \\
\hline \multirow[t]{2}{*}{13} & Right & -0.8 & 1.4 & -0.4 & 0 & -0.08 & 81 \\
\hline & Left & 1 & 1.1 & 0.5 & 0.6 & 0.63 & 87 \\
\hline \multirow[t]{2}{*}{14} & Right & -2.2 & 0.4 & 0 & 0.3 & -0.23 & 95 \\
\hline & Left & -0.9 & 0.1 & 0 & 0.6 & 0.56 & 82 \\
\hline \multirow[t]{2}{*}{32} & Right & -3 & -0.3 & -1.2 & 1.5 & 0.94 & 90 \\
\hline & Left & -1.7 & 1.4 & 0 & 2 & 0.22 & 94 \\
\hline \multirow[t]{2}{*}{41} & Right & 7.1 & 0.6 & 4.1 & 0.9 & 0.66 & 93 \\
\hline & Left & 7.2 & 0.8 & 4.8 & 1.3 & 1.15 & 98 \\
\hline \multirow[t]{2}{*}{50} & Right & -0.4 & 0.7 & 0.5 & 2.5 & 0.28 & 92 \\
\hline & Left & -1.6 & 0.7 & -0.1 & 1.6 & 0.43 & 82 \\
\hline
\end{tabular}




\begin{tabular}{|c|c|c|c|c|c|c|c|}
\hline & & \multicolumn{6}{|c|}{ Second Premolar (P2) } \\
\hline \multicolumn{2}{|c|}{ Cast Number } & D3 & $\mathrm{D} 1$ & D2 & D4 & DWALA & LAI (Degrees) \\
\hline \multirow[t]{2}{*}{1} & Right & 2 & -0.3 & 2.2 & 2.1 & 1.78 & 100 \\
\hline & Left & 0.8 & -0.2 & 1.9 & 2.1 & 0.9 & 101 \\
\hline \multirow[t]{2}{*}{2} & Right & -2.7 & 0.7 & -0.9 & 2.9 & 0.98 & 94 \\
\hline & Left & -2.4 & 1.6 & -0.1 & 2.7 & 1.96 & 99 \\
\hline \multirow[t]{2}{*}{3} & Right & -1.1 & -0.3 & 0 & 1.5 & -0.09 & 88 \\
\hline & Left & -1.2 & 0.3 & 0.1 & 2.2 & -0.13 & 93 \\
\hline \multirow[t]{2}{*}{4} & Right & -2.8 & 0.4 & -1.9 & 0.9 & 1.71 & 105 \\
\hline & Left & -1.3 & 1.1 & 0 & 1.1 & -0.08 & 101 \\
\hline \multirow[t]{2}{*}{5} & Right & -1.9 & 0 & -0.5 & 1 & -0.07 & 93 \\
\hline & Left & -1.9 & 0.5 & -0.8 & 1.8 & 0.45 & 92 \\
\hline \multirow[t]{2}{*}{6} & Right & -1.1 & 0.2 & -0.4 & 1.4 & -0.02 & 91 \\
\hline & Left & -1.7 & 0.4 & 0 & 1.7 & 1.07 & 96 \\
\hline \multirow[t]{2}{*}{7} & Right & -3 & -0.4 & -1.5 & 2.2 & 1.68 & 93 \\
\hline & Left & -0.8 & -0.2 & 0 & 3 & 0.64 & 96 \\
\hline \multirow[t]{2}{*}{8} & Right & -3.2 & 0.6 & -1.2 & 0.8 & 0.05 & 95 \\
\hline & Left & -2.7 & 2.6 & -1.2 & 0.1 & 0.24 & 87 \\
\hline \multirow[t]{2}{*}{9} & Right & -3 & 1.2 & 0 & 1.1 & 1.5 & 95 \\
\hline & Left & -2.7 & 0.9 & -1.2 & 1.6 & 0.79 & 86 \\
\hline \multirow[t]{2}{*}{10} & Right & -2.3 & -0.5 & 0 & 1.8 & 0.45 & 92 \\
\hline & Left & -0.9 & 0 & 1.3 & 2.4 & 1.12 & 95 \\
\hline \multirow[t]{2}{*}{11} & Right & 1.7 & 0.2 & 2.1 & 2 & 0.28 & 97 \\
\hline & Left & 2.6 & 0.6 & 2.6 & 1.1 & -0.76 & 90 \\
\hline \multirow[t]{2}{*}{12} & Right & -3.4 & -0.6 & -1.1 & 1.3 & 1.19 & 89 \\
\hline & Left & -3.2 & 0.7 & -1.5 & 0 & 0.8 & 90 \\
\hline \multirow[t]{2}{*}{13} & Right & -2.7 & 0.5 & -1 & 0.6 & 0.53 & 97 \\
\hline & Left & -1.1 & 0.2 & -0.7 & 1.3 & 0.51 & 97 \\
\hline \multirow[t]{2}{*}{14} & Right & -1.9 & 0.6 & 0.4 & 2.3 & -0.28 & 94 \\
\hline & Left & -2.4 & 1.6 & -0.4 & 2.6 & 0.6 & 89 \\
\hline \multirow[t]{2}{*}{32} & Right & -4.5 & 0.3 & -3 & 1.5 & 0.82 & 99 \\
\hline & Left & -3.2 & 0 & -2 & 2.1 & 0.38 & 103 \\
\hline \multirow[t]{2}{*}{41} & Right & 3.3 & 0.3 & 3.6 & 2.1 & 1.31 & 99 \\
\hline & Left & 3.5 & 0.8 & 3.1 & 1.7 & 1.16 & 102 \\
\hline \multirow[t]{2}{*}{50} & Right & -1.9 & 0 & -1.6 & 2.9 & 0.93 & 87 \\
\hline & Left & -1.3 & 0.2 & 0.1 & 1.4 & 0.96 & 98 \\
\hline
\end{tabular}




\begin{tabular}{|c|c|c|c|c|c|c|c|}
\hline & & \multicolumn{6}{|c|}{ First Molar (M1) } \\
\hline \multicolumn{2}{|c|}{ Cast Number } & D3 & D1 & D2 & D4 & DWALA & LAI (Degrees) \\
\hline \multirow[t]{2}{*}{1} & Right & 1 & -0.1 & 2.2 & 0.6 & 1.93 & 110 \\
\hline & Left & 0.9 & 0.4 & 3.2 & 0.5 & 0.3 & 100 \\
\hline \multirow[t]{2}{*}{2} & Right & -5.4 & -0.2 & -2.2 & 0.3 & 0.63 & 111 \\
\hline & Left & -4.7 & 0.1 & -2 & 0 & 1.37 & 115 \\
\hline \multirow[t]{2}{*}{3} & Right & -0.8 & 0.3 & 1 & 0 & 0.34 & 102 \\
\hline & Left & -0.7 & 0.8 & 1.2 & 1.1 & 0.89 & 109 \\
\hline \multirow[t]{2}{*}{4} & Right & 0 & -0.4 & 0 & 0.5 & 1.34 & 118 \\
\hline & Left & -1.9 & 0.6 & -1.7 & 1.6 & -0.63 & 97 \\
\hline \multirow[t]{2}{*}{5} & Right & -2.6 & 0.3 & -0.9 & 0.4 & 0.17 & 104 \\
\hline & Left & -2.3 & 1 & -0.1 & 0.2 & 0.04 & 103 \\
\hline \multirow[t]{2}{*}{6} & Right & -3.9 & -0.6 & -3.1 & 1.4 & 0.34 & 104 \\
\hline & Left & -4.9 & -0.9 & -3.4 & 1.7 & 0.48 & 105 \\
\hline \multirow[t]{2}{*}{7} & Right & -2.5 & -0.3 & -2.1 & 0.2 & 0.09 & 103 \\
\hline & Left & -1 & 0.3 & -0.4 & 0 & -0.08 & 105 \\
\hline \multirow[t]{2}{*}{8} & Right & -4.7 & 0.3 & -1.8 & 0.6 & 0.55 & 106 \\
\hline & Left & -5.6 & -0.1 & -3.9 & 1.6 & 0.32 & 102 \\
\hline \multirow[t]{2}{*}{9} & Right & -2.5 & 0.4 & 2.8 & 0.4 & 1.42 & 116 \\
\hline & Left & -0.5 & 0 & 2.7 & 0.9 & 0.81 & 110 \\
\hline \multirow[t]{2}{*}{10} & Right & -3.3 & 0 & -0.7 & 0.8 & 0.54 & 106 \\
\hline & Left & -1.2 & 0.7 & 0.2 & 1.1 & 1.19 & 99 \\
\hline \multirow[t]{2}{*}{11} & Right & -1.9 & 0.6 & 0.6 & 1.7 & 0.52 & 100 \\
\hline & Left & -0.5 & 0.4 & 1.1 & 1.4 & -0.46 & 102 \\
\hline \multirow[t]{2}{*}{12} & Right & -1.1 & 0.6 & 0 & 0.6 & 1.46 & 107 \\
\hline & Left & -3.8 & 0.4 & -2.2 & 0.5 & 1.34 & 109 \\
\hline \multirow[t]{2}{*}{13} & Right & -3 & 0.1 & -0.6 & 0.7 & 1.43 & 112 \\
\hline & Left & -1.9 & -0.2 & 0 & 1 & 0.82 & 111 \\
\hline \multirow[t]{2}{*}{14} & Right & -2.3 & -0.6 & 0.3 & 0.4 & 0.11 & 104 \\
\hline & Left & -2.6 & 0 & -0.7 & 0.6 & 0.35 & 103 \\
\hline \multirow[t]{2}{*}{32} & Right & -4.2 & 0.9 & -2.1 & 0.2 & 1.4 & 117 \\
\hline & Left & -2.7 & 0.8 & -2.6 & 1.3 & 1.26 & 119 \\
\hline \multirow[t]{2}{*}{41} & Right & 2.3 & 0 & 2.8 & 1 & 1.15 & 103 \\
\hline & Left & 2.4 & 1.4 & 3.2 & 2.5 & 1.21 & 105 \\
\hline \multirow[t]{2}{*}{50} & Right & -0.6 & 0 & 0 & 2.4 & 0.36 & 106 \\
\hline & Left & -1.4 & 0.3 & -0.8 & 1.2 & 0.49 & 105 \\
\hline
\end{tabular}




\begin{tabular}{|c|c|c|c|c|c|c|c|}
\hline & & \multicolumn{6}{|c|}{ Second Molar (M2) } \\
\hline \multicolumn{2}{|c|}{ Cast Number } & D3 & D1 & $\mathrm{D} 2$ & $\mathrm{D} 4$ & DWALA & LAI (Degrees) \\
\hline \multirow[t]{2}{*}{1} & Right & -2.2 & 0.9 & 2.2 & 2.1 & 1.82 & 105 \\
\hline & Left & -3.3 & 0.4 & 1.5 & 2.2 & 0.34 & 104 \\
\hline \multirow[t]{2}{*}{2} & Right & -4.9 & 0 & -3.1 & 1.1 & 0.37 & 109 \\
\hline & Left & -6.9 & -1.9 & -3.8 & 1.1 & -0.76 & 122 \\
\hline \multirow[t]{2}{*}{3} & Right & -4.1 & -0.7 & -3 & 0.3 & 0.59 & 99 \\
\hline & Left & -3.3 & -0.7 & -2.9 & 1 & 1.39 & 106 \\
\hline \multirow[t]{2}{*}{4} & Right & -0.3 & -1.5 & 0.6 & 2.6 & 1.05 & 123 \\
\hline & Left & -0.6 & -2.3 & 0 & 2.4 & 2.11 & 116 \\
\hline \multirow[t]{2}{*}{5} & Right & -4 & 0 & -2.3 & 0 & 0.05 & 106 \\
\hline & Left & -1.6 & 0.4 & -0.6 & 1.5 & 0.83 & 109 \\
\hline \multirow[t]{2}{*}{6} & Right & -4 & -0.9 & -1.1 & 1.9 & 1.14 & 116 \\
\hline & Left & -5.4 & -2.1 & -2.9 & 3.4 & 1.1 & 113 \\
\hline \multirow[t]{2}{*}{7} & Right & -3.7 & -1.9 & -2.5 & 1.1 & 0.46 & 102 \\
\hline & Left & -1.9 & -1.5 & -1.5 & 2.6 & 1.55 & 108 \\
\hline \multirow[t]{2}{*}{8} & Right & -5.5 & -0.6 & -2.4 & 1.8 & 1.58 & 115 \\
\hline & Left & -7.7 & -2.1 & -3.8 & 0.6 & 1.08 & 106 \\
\hline \multirow[t]{2}{*}{9} & Right & -5.6 & 0 & -1.8 & 0.5 & 0.8 & 104 \\
\hline & Left & -3.5 & 0.6 & -0.7 & 1.4 & 1.28 & 114 \\
\hline \multirow[t]{2}{*}{10} & Right & -4 & -0.9 & -2.2 & 1.5 & 1.05 & 113 \\
\hline & Left & -2.2 & 0 & -1.6 & 2.2 & 1.56 & 109 \\
\hline \multirow[t]{2}{*}{11} & Right & -3.9 & 0.5 & -1.9 & 1 & 0.47 & 112 \\
\hline & Left & -2.6 & 0.3 & -2.7 & 0.7 & 0.73 & 107 \\
\hline \multirow[t]{2}{*}{12} & Right & -2 & 0 & -0.8 & 1.3 & 1.62 & 113 \\
\hline & Left & -3.3 & -0.5 & -2.5 & 2.4 & 1.92 & 118 \\
\hline \multirow[t]{2}{*}{13} & Right & -5.8 & 0 & -4.3 & 1.2 & 0.42 & 103 \\
\hline & Left & -3.4 & 0 & -2.8 & 1.4 & 0.94 & 105 \\
\hline \multirow[t]{2}{*}{14} & Right & -3 & 0 & -0.6 & 1.5 & 1 & 114 \\
\hline & Left & -3.7 & 0.4 & -2.9 & 0.1 & 0.22 & 106 \\
\hline \multirow[t]{2}{*}{32} & Right & -3.7 & -1.5 & -2.3 & 1.2 & 1.66 & 122 \\
\hline & Left & -4.2 & -1.4 & -2.3 & 1.8 & 1.72 & 124 \\
\hline \multirow[t]{2}{*}{41} & Right & 1.1 & -1.1 & 0.4 & 2.6 & 1.41 & 110 \\
\hline & Left & -0.2 & 0.7 & 0.9 & 2.88 & 2.12 & 112 \\
\hline \multirow[t]{2}{*}{50} & Right & -1.4 & -2.5 & 0.2 & 1.5 & 1.19 & 110 \\
\hline & Left & -3.2 & -1.8 & -1.8 & 2.2 & 0.58 & 117 \\
\hline
\end{tabular}




\section{Statistician DATA}
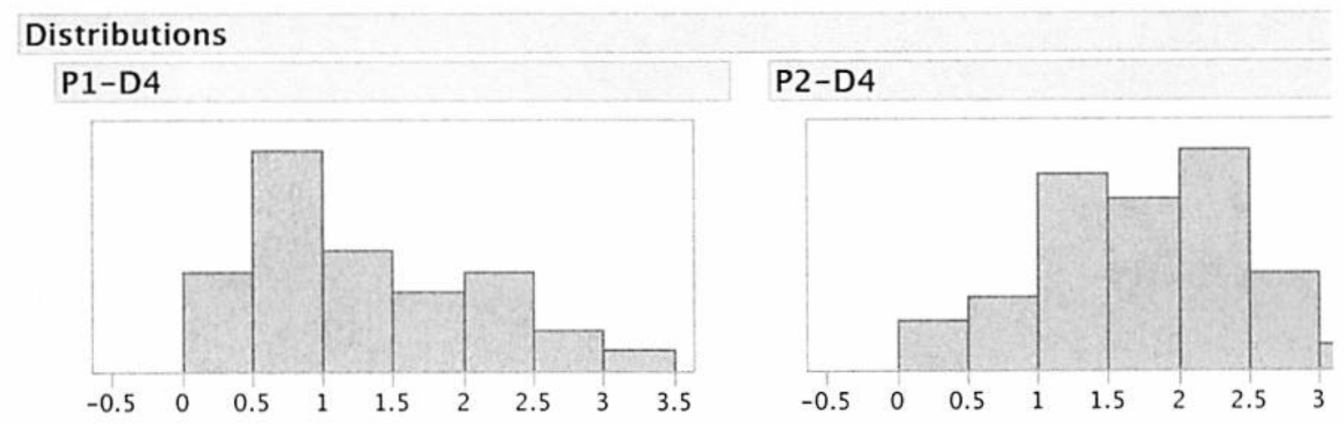

\begin{tabular}{|c|c|c|}
\hline \multicolumn{3}{|c|}{ Quantiles } \\
\hline $100.0 \%$ & maximum & 3.1 \\
\hline $99.5 \%$ & & 3.1 \\
\hline $97.5 \%$ & & 3.1 \\
\hline $90.0 \%$ & & 2.45 \\
\hline $75.0 \%$ & quartile & 1.925 \\
\hline $50.0 \%$ & median & 1.15 \\
\hline $25.0 \%$ & quartile & 0.6 \\
\hline $10.0 \%$ & & 0.3 \\
\hline $2.5 \%$ & & 0 \\
\hline $0.5 \%$ & & 0 \\
\hline $0.0 \%$ & minimum & 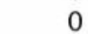 \\
\hline
\end{tabular}

\begin{tabular}{|c|c|c|}
\hline \\
\hline \\
\hline \multirow{2}{*}{\multicolumn{3}{|c|}{$\begin{array}{l}100.0 \% \text { maximum } \\
99.5 \% \\
97.5 \%\end{array}$}} \\
\hline \multirow{2}{*}{\multicolumn{2}{|c|}{$\begin{array}{l}97.5 \% \\
90.0 \%\end{array}$}} & \\
\hline & & 2. \\
\hline \multicolumn{2}{|l|}{$\begin{array}{l}90.0 \% \\
75.0 \%\end{array}$} & 2. \\
\hline \multirow{2}{*}{\multicolumn{2}{|c|}{$\begin{array}{l}\text { median } \\
\text { quartile }\end{array}$}} & 1. \\
\hline & quartile & 1. \\
\hline \multicolumn{2}{|l|}{$10.0 \%$} & 0. \\
\hline \multicolumn{3}{|l|}{$2.5 \%$} \\
\hline \multicolumn{2}{|l|}{$0.5 \%$} & \\
\hline \multicolumn{2}{|l|}{$0.0 \%$} & \\
\hline
\end{tabular}

Summary Statistics

Mean 1.25

Std Dev $\quad 0.8117508$

Std Err Mean 0.1392141

Upper 95\% Mean 1.5332333

Lower 95\% Mean 0.9667667

$\mathrm{N}$

34

Test Mean

Hypothesized Value 0

Actual Estimate $\quad 1.25$

DF

33

Std Dev $\quad 0.81175$

t Test

Test Statistic 8.9790

Prob $>|\mathrm{t}|<.0001$

Prob $>\mathrm{t} \quad<.0001$

Prob $<\mathrm{t} \quad 1.0000$

Summary Statistics

Mean $\quad 1.6852941$

Std Dev $\quad 0.7536305$

Std Err Mean 0.1292466

Upper 95\% Mean 1.9482482

Lower 95\% Mean 1.42234

$\mathrm{N}$

Test Mean

Hypothesized Value 0

Actual Estimate $\quad 1.68529$

DF

Std Dev

t Test

Test Statistic 13.0394

Prob $>|\mathrm{t}|$

Prob $>\mathrm{t} \quad<.0001$

Prob $<\mathrm{t} \quad 1.0000$
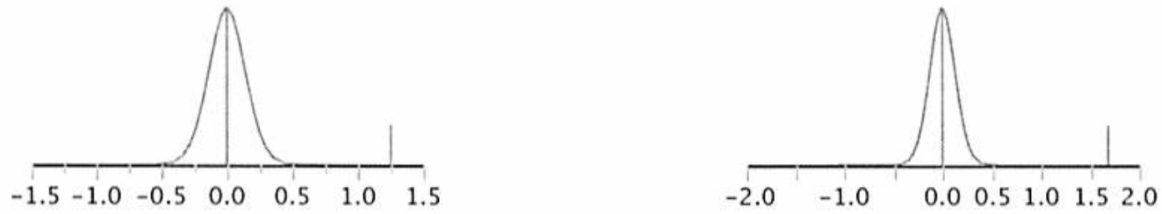

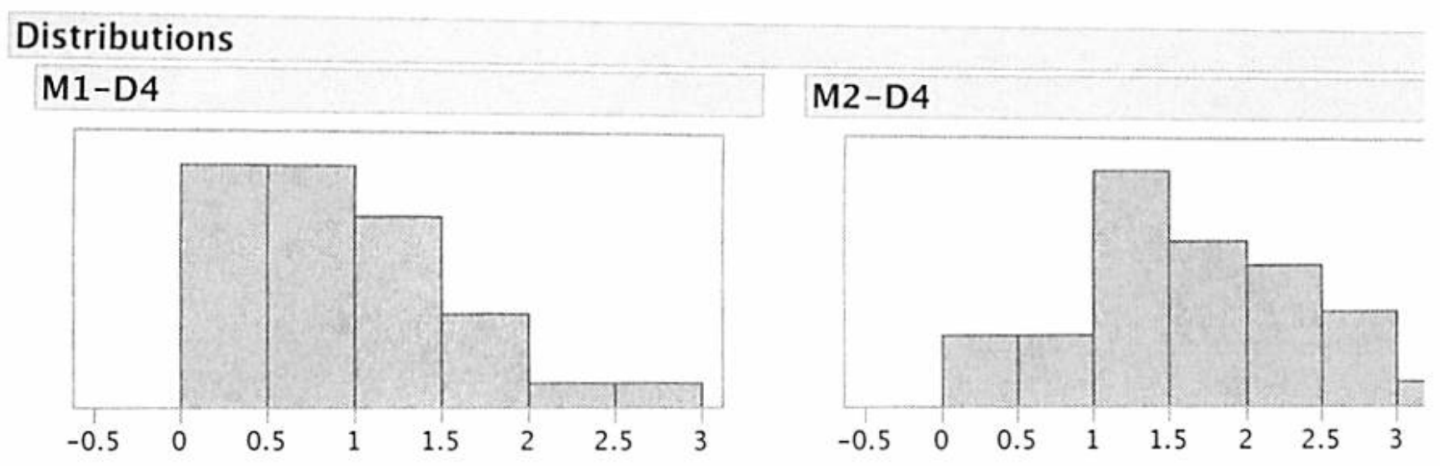

\begin{tabular}{|c|c|c|}
\hline \multicolumn{3}{|c|}{ Quantiles } \\
\hline $100.0 \%$ & maximum & 2.5 \\
\hline $99.5 \%$ & & 2.5 \\
\hline $97.5 \%$ & & 2.5 \\
\hline $90.0 \%$ & & 1.7 \\
\hline $75.0 \%$ & quartile & 1.325 \\
\hline $50.0 \%$ & median & 0.65 \\
\hline $25.0 \%$ & quartile & 0.4 \\
\hline $10.0 \%$ & & 0.1 \\
\hline $2.5 \%$ & & 0 \\
\hline $0.5 \%$ & & 0 \\
\hline $0.0 \%$ & minimum & 0 \\
\hline
\end{tabular}

\begin{tabular}{|c|c|c|}
\hline \multicolumn{3}{|c|}{ Quantiles } \\
\hline $100.0 \%$ & maximum & 3.4 \\
\hline $99.5 \%$ & & 3.4 \\
\hline $97.5 \%$ & & 3.4 \\
\hline $90.0 \%$ & & 2.6 \\
\hline $75.0 \%$ & quartile & 2.2 \\
\hline $50.0 \%$ & median & 1.5 \\
\hline $25.0 \%$ & quartile & 1.075 \\
\hline $10.0 \%$ & & 0.4 \\
\hline $2.5 \%$ & & 0 \\
\hline $0.5 \%$ & & 0 \\
\hline $0.0 \%$ & minimum & 0 \\
\hline
\end{tabular}

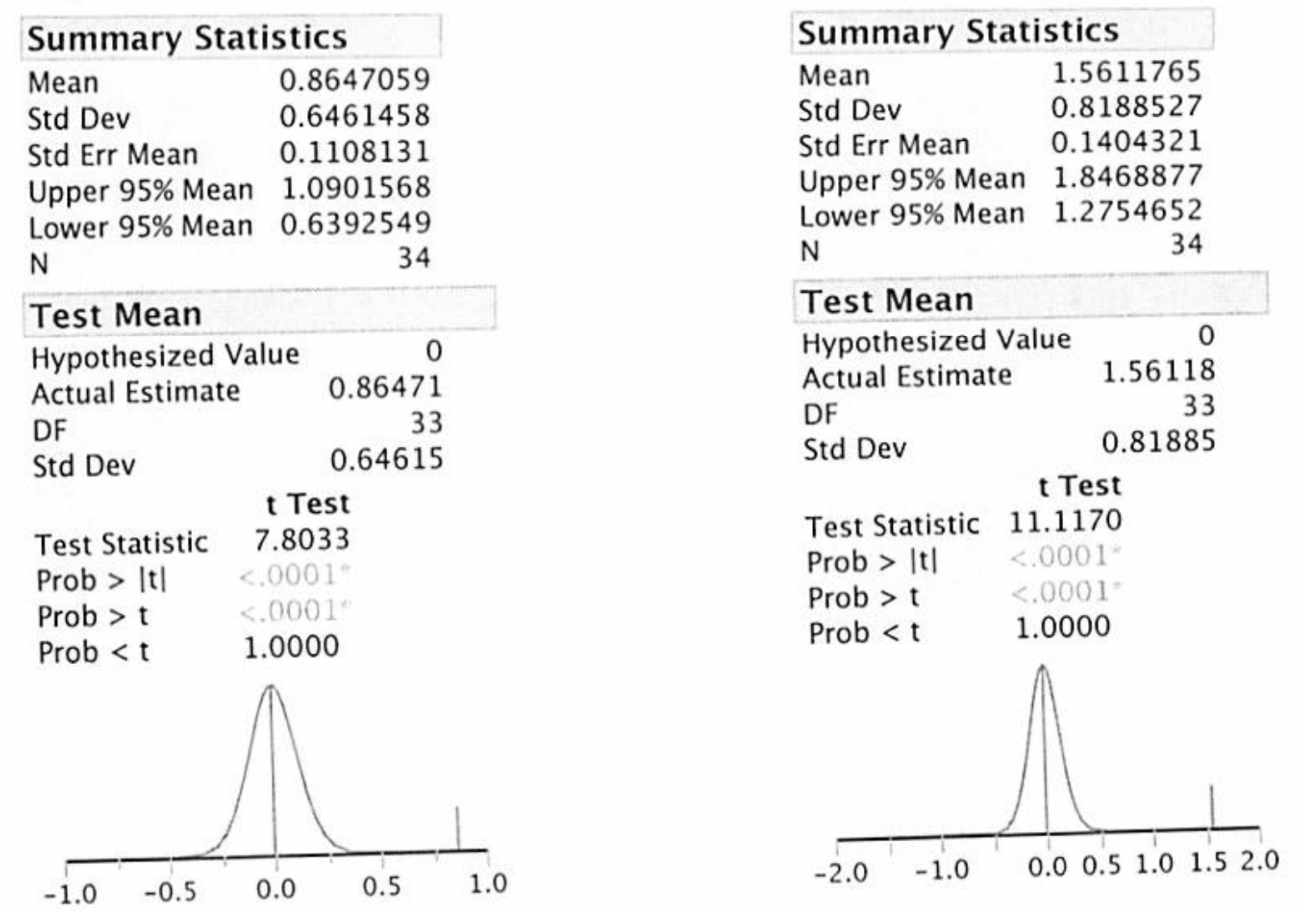



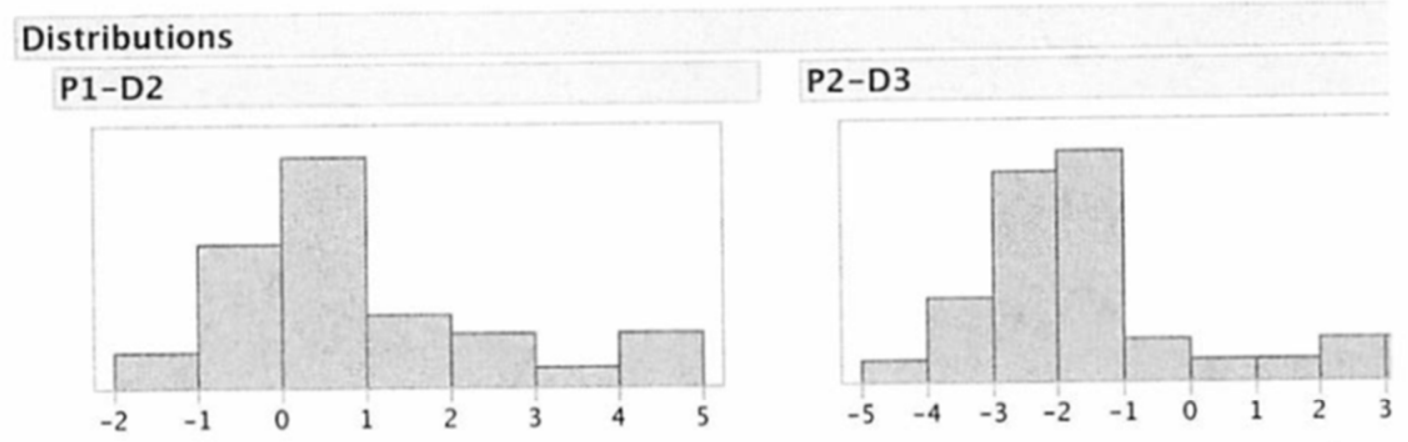

\begin{tabular}{|c|c|c|}
\hline \multicolumn{3}{|c|}{ Quantiles } \\
\hline $100.0 \%$ & maximum & 4.8 \\
\hline $99.5 \%$ & & 4.8 \\
\hline $97.5 \%$ & & 4.8 \\
\hline $90.0 \%$ & & 3.55 \\
\hline $75.0 \%$ & quartile & 1.725 \\
\hline $50.0 \%$ & median & 0.5 \\
\hline $25.0 \%$ & quartile & -0.25 \\
\hline $10.0 \%$ & & -0.9 \\
\hline $2.5 \%$ & & -1.9 \\
\hline $0.5 \%$ & & -1.9 \\
\hline $0.0 \%$ & minimum & -1.9 \\
\hline
\end{tabular}

\begin{tabular}{|c|c|c|}
\hline \multicolumn{3}{|c|}{ Quantiles } \\
\hline $100.0 \%$ & maximum & 3.5 \\
\hline $99.5 \%$ & & 3.5 \\
\hline $97.5 \%$ & & 3.5 \\
\hline $90.0 \%$ & & 2.3 \\
\hline $75.0 \%$ & quartile & -1.05 \\
\hline $50.0 \%$ & median & -1.9 \\
\hline $25.0 \%$ & quartile & -2.725 \\
\hline $10.0 \%$ & & -3.2 \\
\hline $2.5 \%$ & & -4.5 \\
\hline $0.5 \%$ & & -4.5 \\
\hline $0.0 \%$ & minimum & -4.5 \\
\hline
\end{tabular}

\section{Summary Statistics}

$\begin{array}{lr}\text { Mean } & 0.8382353 \\ \text { Std Dev } & 1.6018956 \\ \text { Std Err Mean } & 0.2747228 \\ \text { Upper 95\% Mean } & 1.3971631 \\ \text { Lower 95\% Mean } & 0.2793075 \\ \mathrm{~N} & 34\end{array}$

Test Mean

$\begin{array}{lr}\text { Hypothesized Value } & 0 \\ \text { Actual Estimate } & 0.83824\end{array}$

DF 33

Std Dev $\quad 1.6019$

$\begin{array}{lr}\text { Test Statistic } & \mathbf{t} \text { Test } \\ \text { Prob }>|\mathrm{t}| & 0.0012 \\ \text { Prob }>\mathrm{t} & 0.0025^{\circ} \\ \text { Prob }<\mathrm{t} & \mathbf{0 . 9 9 7 8}\end{array}$

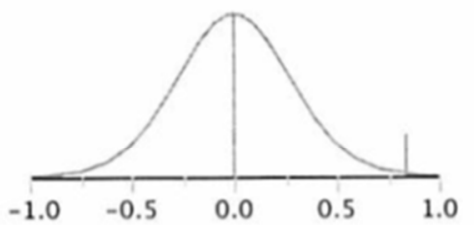

Summary Statistics

$\begin{array}{lr}\text { Mean } & -1.423529 \\ \text { Std Dev } & 1.9855629 \\ \text { Std Err Mean } & 0.3405212 \\ \text { Upper 95\% Mean } & -0.730734 \\ \text { Lower 95\% Mean } & -2.116325 \\ \text { N } & 34\end{array}$

$\mathrm{N}$

Test Mean

$\begin{array}{lr}\text { Hypothesized Value } & 0 \\ \text { Actual Estimate } & -1.4235\end{array}$

Actual Estimate $\quad-1.423$

Std Dev

1.98556

Test Statistic $\quad-4.1804$

Prob $>|t| \quad 0.0002$

Prob $>\mathrm{t} \quad 0.9999$

Prob $<\mathrm{t} \quad 0.0001$

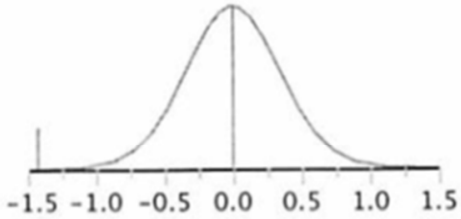



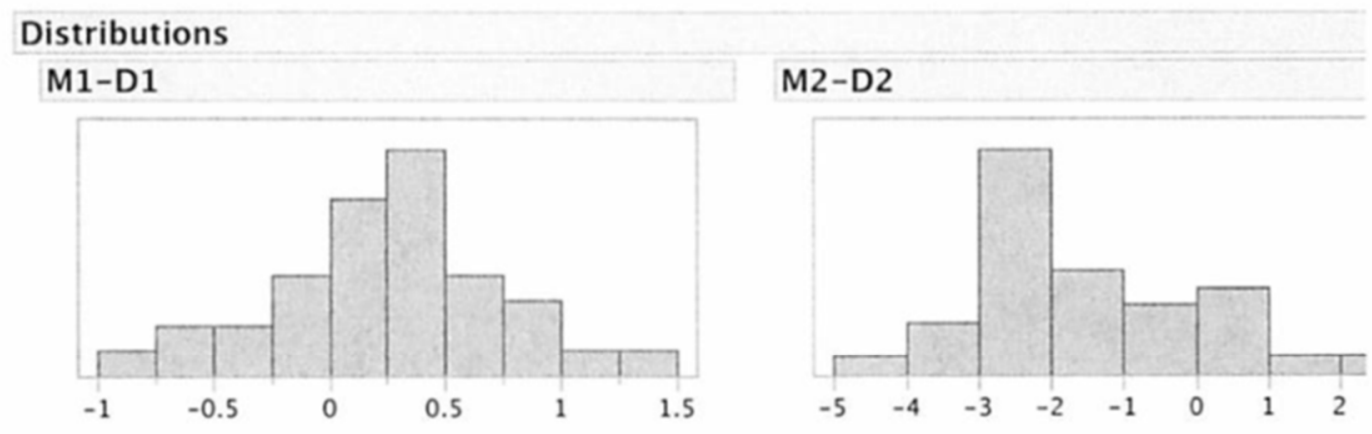

\begin{tabular}{|c|c|c|}
\hline \multicolumn{3}{|c|}{ Quantiles } \\
\hline $100.0 \%$ & maximum & 1.4 \\
\hline $99.5 \%$ & & 1.4 \\
\hline $97.5 \%$ & & 1.4 \\
\hline $90.0 \%$ & & 0.85 \\
\hline $75.0 \%$ & quartile & 0.6 \\
\hline $50.0 \%$ & median & 0.3 \\
\hline $25.0 \%$ & quartile & -0.1 \\
\hline $10.0 \%$ & & -0.5 \\
\hline $2.5 \%$ & & -0. \\
\hline $0.5 \%$ & & -0.5 \\
\hline $0.0 \%$ & minimum & -0 \\
\hline
\end{tabular}

Summary Statistics

Std Dev $\quad 0.4936766$

Std Err Mean $\quad 0.0846648$

Upper 95\% Mean 0.3869578

Lower $95 \%$ Mean $\quad 0.042454$

N

Test Mean

Hypothesized Value

Actual Estimate

DF

Std Dev

71

33

Test Statistic $\quad 2.5360$

Prob $>|\mathbf{t}| \quad 0.0161^{4}$

Prob $>\mathbf{t} \quad 0.0081$

Prob $<\mathrm{t} \quad 0.9919$

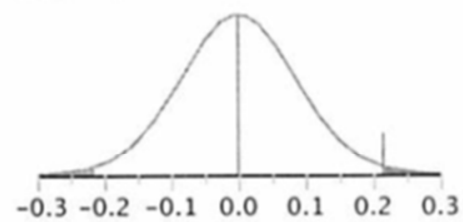

\section{Quantiles}

$100.0 \%$ maximum $\quad 2.2$

$99.5 \%$

$97.5 \%$

$90.0 \%$

$75.0 \%$

$50.0 \%$

$25.0 \%$

$10.0 \%$

$2.5 \%$

$0.5 \%$

$0.0 \%$

$\begin{array}{cr} & 2.2 \\ & 2.2 \\ & 0.75 \\ \text { quartile } & -0.6 \\ \text { median } & -2.05 \\ \text { quartile } & -2.825 \\ & -3.45 \\ & -4.3 \\ & -4.3 \\ \text { minimum } & -4.3\end{array}$

\section{Summary Statistics}

$\begin{array}{lr}\text { Mean } & -1.626471 \\ \text { Std Dev } & 1.5742836 \\ \text { Std Err Mean } & 0.2699874 \\ \text { Upper 95\% Mean } & -1.077177 \\ \text { Lower 95\% Mean } & -2.175764 \\ \mathrm{~N} & 34\end{array}$

Test Mean

Hypothesized Value 0

Actual Estimate $\quad-1.6265$

DF

Std Dev

33

1.57428

\section{t Test}

Test Statistic $\quad-6.0242$

Prob $>|\mathrm{t}| \quad<.0001$

Prob $>\mathrm{t} \quad 1.0000$

Prob $<\mathrm{t}<.0001$

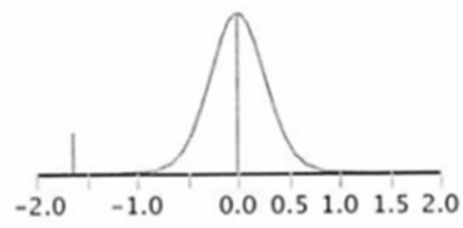




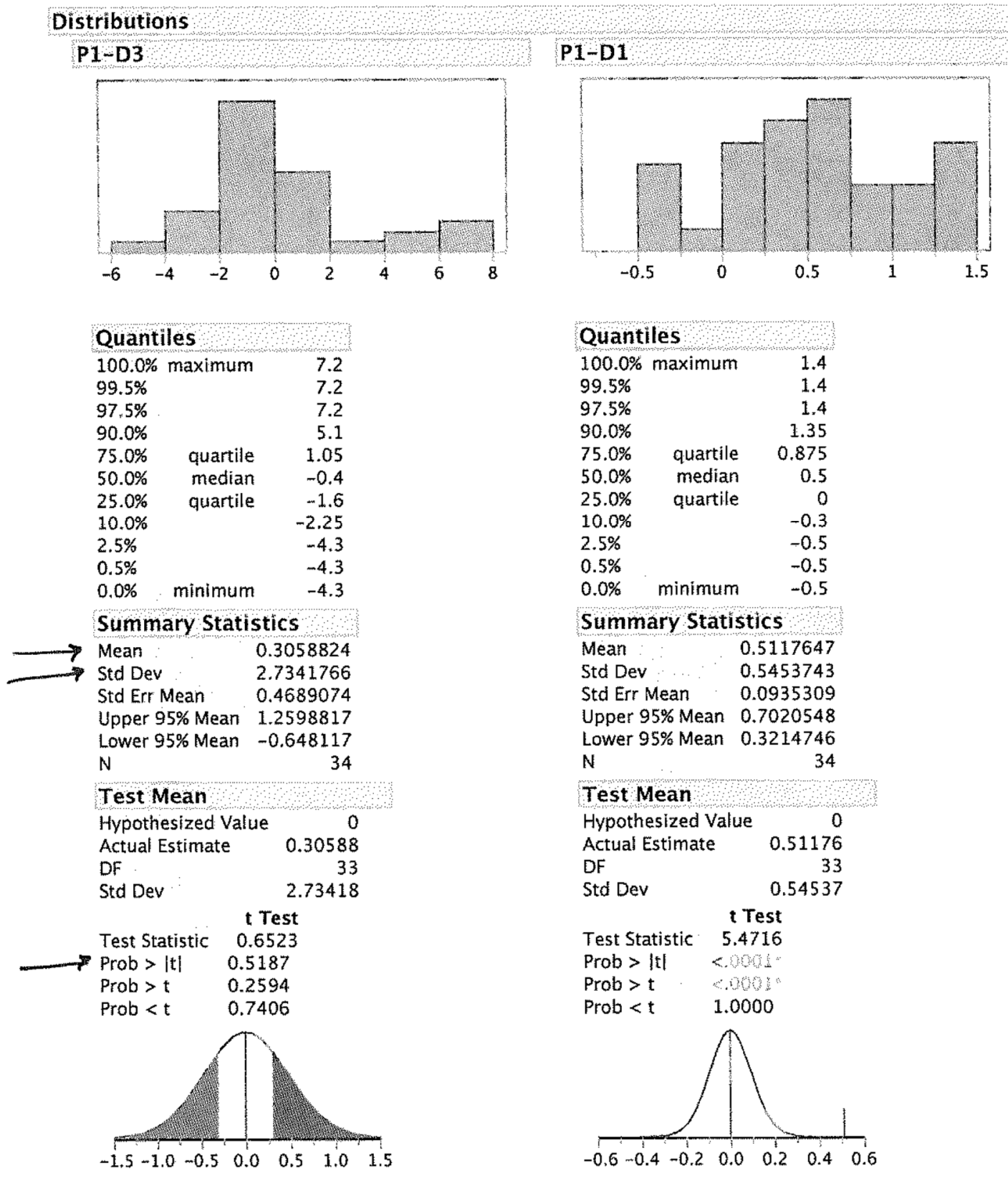




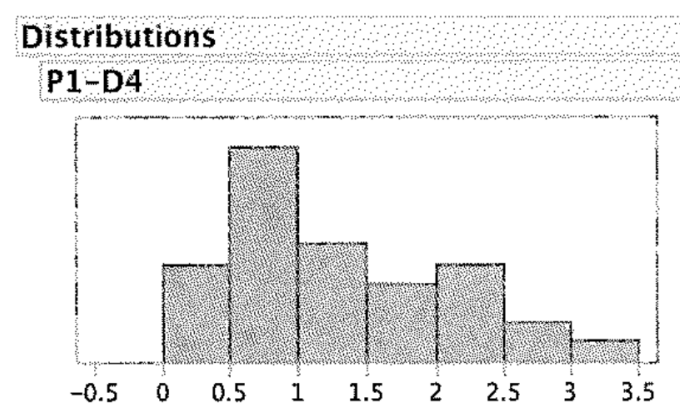

\section{P1-DWALA}
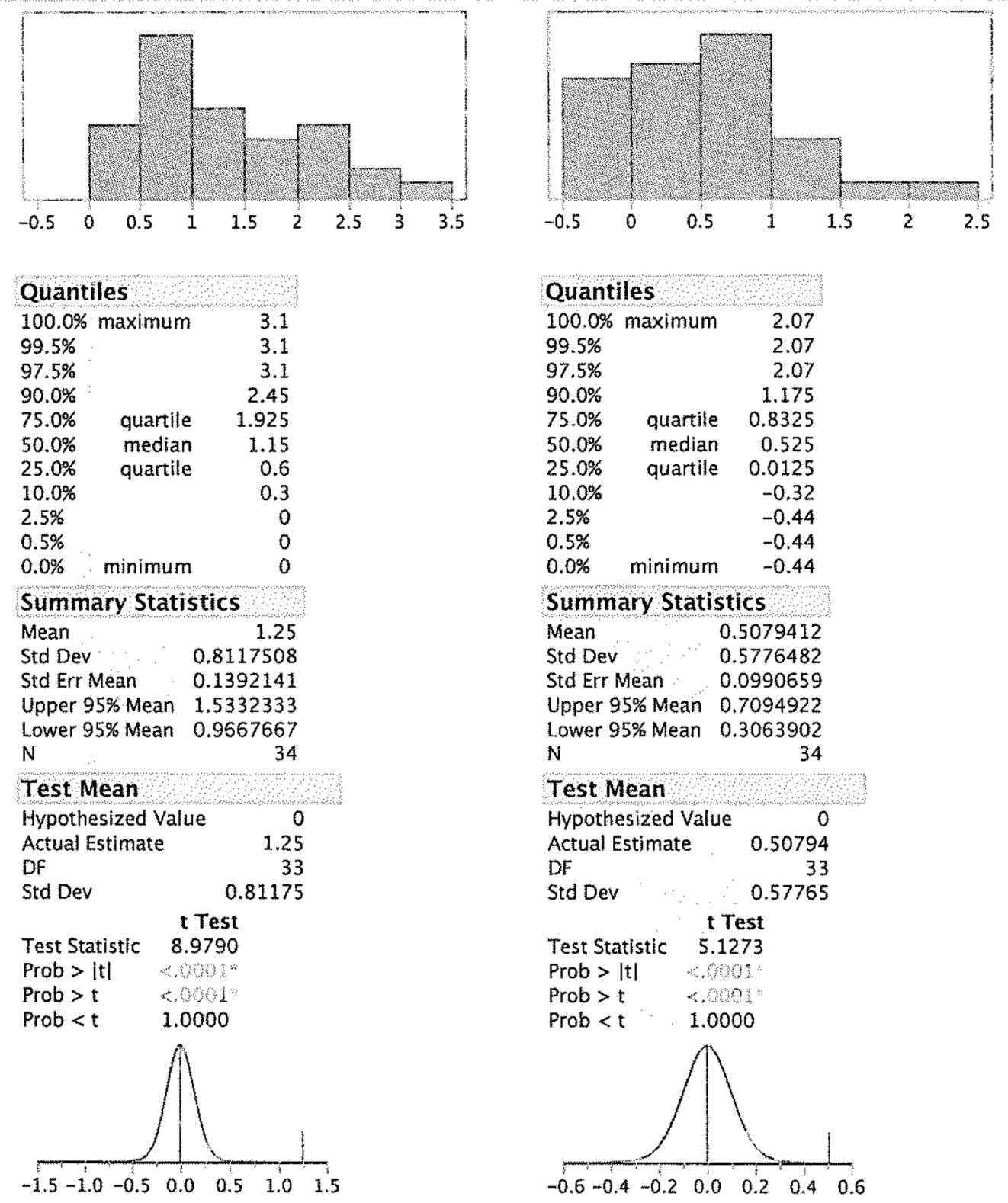

\begin{tabular}{|c|c|c|}
\hline \multicolumn{3}{|c|}{ Quantiles } \\
\hline $100.0 \%$ & maximum & 2.07 \\
\hline $99.5 \%$ & & 2.07 \\
\hline $97.5 \%$ & & 2.07 \\
\hline $90.0 \%$ & & 1.175 \\
\hline $75.0 \%$ & quartile & 0.8325 \\
\hline $50.0 \%$ & median & 0.525 \\
\hline $25.0 \%$ & quartile & 0.0125 \\
\hline $10.0 \%$ & & -0.32 \\
\hline $2.5 \%$ & & -0.44 \\
\hline $0.5 \%$ & & -0.44 \\
\hline $0.0 \%$ & minimum & -0.44 \\
\hline
\end{tabular}

\section{Summary Statistics}

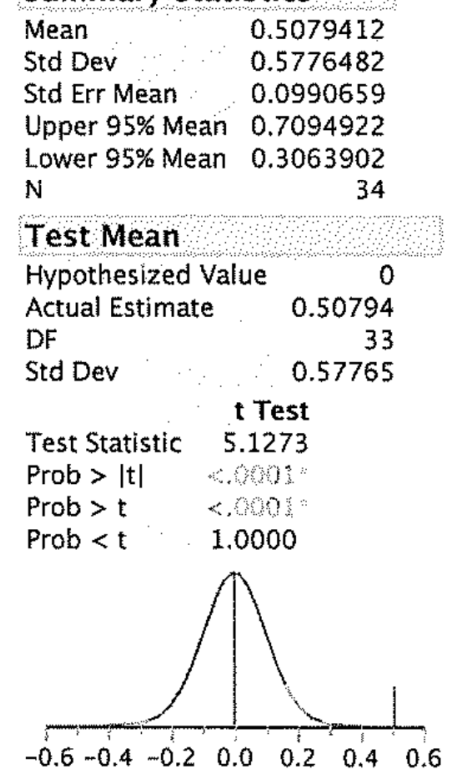




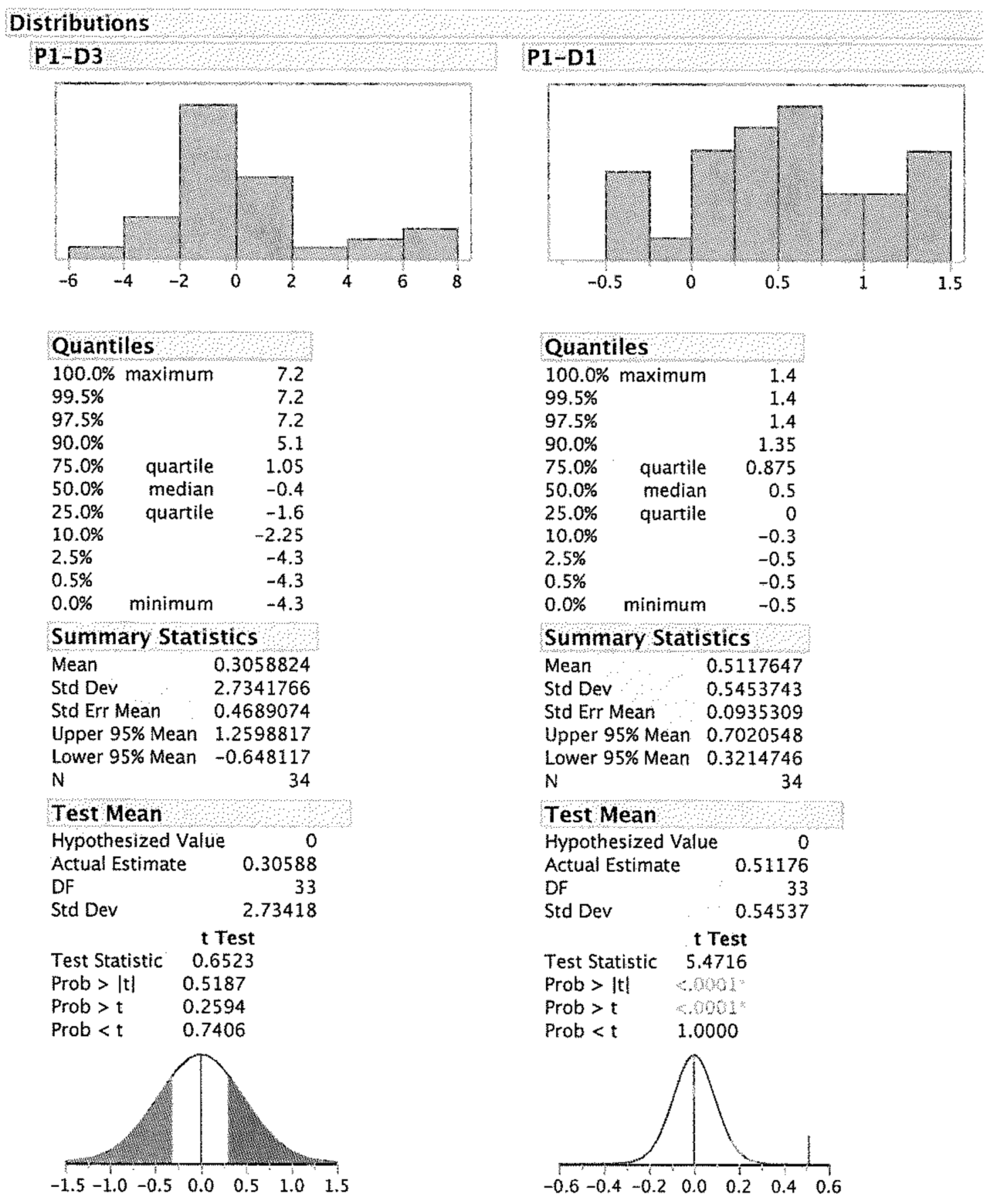




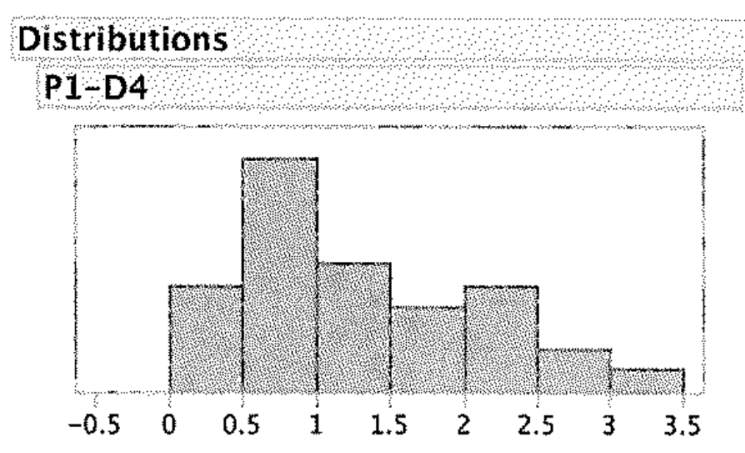

\section{P1-DWALA}

\begin{tabular}{|c|c|c|}
\hline \multicolumn{3}{|c|}{ Quantiles } \\
\hline $100.0 \%$ & maximum & 3.1 \\
\hline $99.5 \%$ & & 3.1 \\
\hline $97.5 \%$ & & 3.1 \\
\hline $90.0 \%$ & & 2.45 \\
\hline $75.0 \%$ & quartife & 1.925 \\
\hline $50.0 \%$ & median & 1.15 \\
\hline $25.0 \%$ & quartile & 0.6 \\
\hline $10.0 \%$ & & 0.3 \\
\hline $2.5 \%$ & & 0 \\
\hline $0.5 \%$ & & 0 \\
\hline $0.0 \%$ & minimum & 0 \\
\hline
\end{tabular}

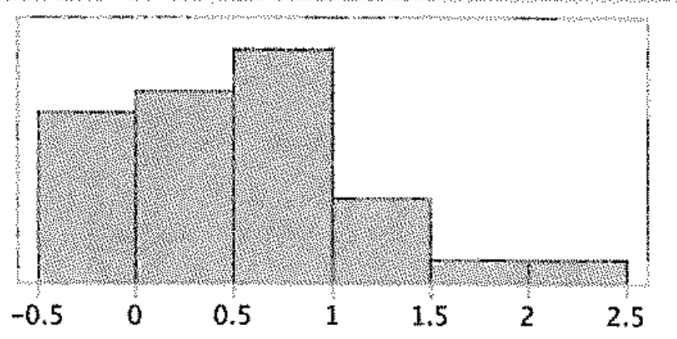

\section{Summary Statistics}

Mean

1.25

Std Dev

0.8117508

Std Err Mean $\quad 0.1392141$

Upper $95 \%$ Mean 1.5332333

Lower $95 \%$ Mean 0.9667667

N

34

\section{Test Mean}

Hypothesized Value

Actual Estimate

DF

Std Dev

1.25

33
0.81175

Prtatistic 8.9790

Prob $>|t| \quad .0001$

Prob $>t$ afent

Prob $<\mathrm{t} \quad 1.0000$

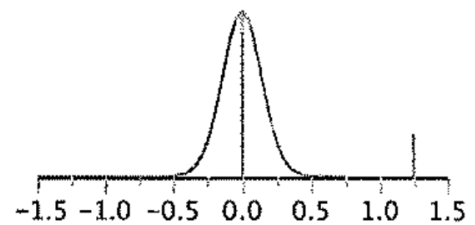

\section{Quantiles}

$\begin{array}{llr}100.0 \% & \text { maximum } & 2.07 \\ 99.5 \% & & 2.07 \\ 97.5 \% & & 2.07 \\ 90.0 \% & & 1.175 \\ 75.0 \% & \text { quartile } & 0.8325 \\ 50.0 \% & \text { median } & 0.525 \\ 25.0 \% & \text { quartile } & 0.0125 \\ 10.0 \% & & -0.32 \\ 2.5 \% & & -0.44 \\ 0.5 \% & & -0.44 \\ 0.0 \% & \text { minimum } & -0.44\end{array}$

Summary Statistics

$\begin{array}{ll}\text { Mean } & 0.5079412 \\ \text { Std Dev } & 0.5776482 \\ \text { Std Err Mean } & 0.0990659 \\ \text { Upper 95\% Mean } & 0.7094922 \\ \text { Lower 95\% Mean } & 0.3063902\end{array}$

N $\quad 34$

Test Mean

Hypothesized Value

Actual Estimate

0

DF

0.50794

Std Dev

0.57765

Test Statistic 5.1273

Prob $>|\mathrm{t}|$

Prob $>\mathrm{t} \quad$ s.pes:

Prob $<\mathrm{t} \quad 1.0000$

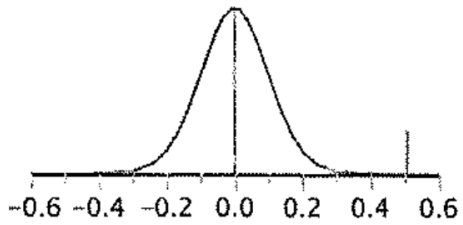




\section{Distributions}

P2-D1

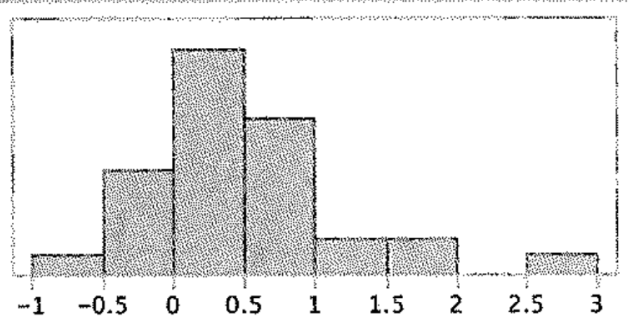

\section{Quantiles}

$100.0 \%$ maximum $\quad 2.6$

$99.5 \%$

$97.5 \%$

$90.0 \%$

$75.0 \%$

$50.0 \%$

$25.0 \%$

$10.0 \%$

$2.5 \%$

$0.5 \%$

$0.0 \%$

Summary Statistics

Mean

Std Dev

Std Err Mean

0.4117647

0.6641306

Upper 95\% Mean 0.6434908

Lower 95\% Mean 0.1800386

$\mathrm{N}$

\section{Test Mean}

Hypothesized Value

Actual Estimate

DF

Std Dev

0.4

0.41176

0.66413

\section{t Test}

Test Statistic $\quad 3.6152$

Prob $>|t| \quad 0.0010$

Prob $>\mathrm{t} \quad 0,000 \mathrm{~s}$

Prob $<t \quad 0.9995$

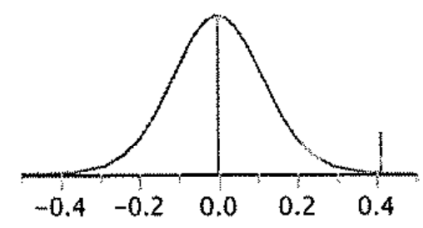

\section{P2 -D2}

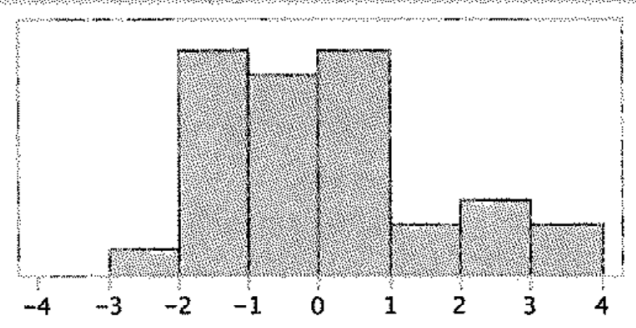

\begin{tabular}{|c|c|c|}
\hline \multicolumn{3}{|c|}{ Quantiles } \\
\hline $100.0 \%$ & maximum & 3.6 \\
\hline $99.5 \%$ & & \\
\hline $97.5 \%$ & & 3.6 \\
\hline $90.0 \%$ & & 2.4 \\
\hline $75.0 \%$ & quartile & 0.175 \\
\hline $50.0 \%$ & median & -0.25 \\
\hline $25.0 \%$ & quartile & -1.2 \\
\hline $10.0 \%$ & & -1.75 \\
\hline $2.5 \%$ & & -3 \\
\hline $0.5 \%$ & & -3 \\
\hline $0.0 \%$ & minimum & -3 \\
\hline
\end{tabular}

Summary Statistics

Mean

$-0.105882$

Std Dev

1.5215505

Std Err Mean . $\quad 0.2609438$

Upper 95\% Mean 0.4250117

Lower $95 \%$ Mean -0.636776

$\mathrm{N}$

Test Mean

Hypothesized Value

Actual Estimate

34

DF

Std Dev

$-0.1059$

33

$t$ Test

Test Statistic $\quad-0.4058$

Prob $>|t| \quad 0.6875$

Prob $>\mathrm{t} \quad 0.6562$

Prob $<\mathrm{t} \quad 0.3438$

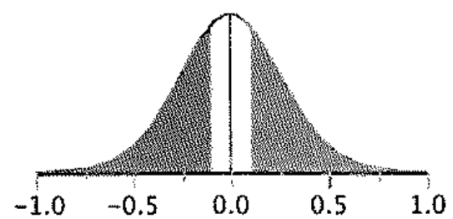



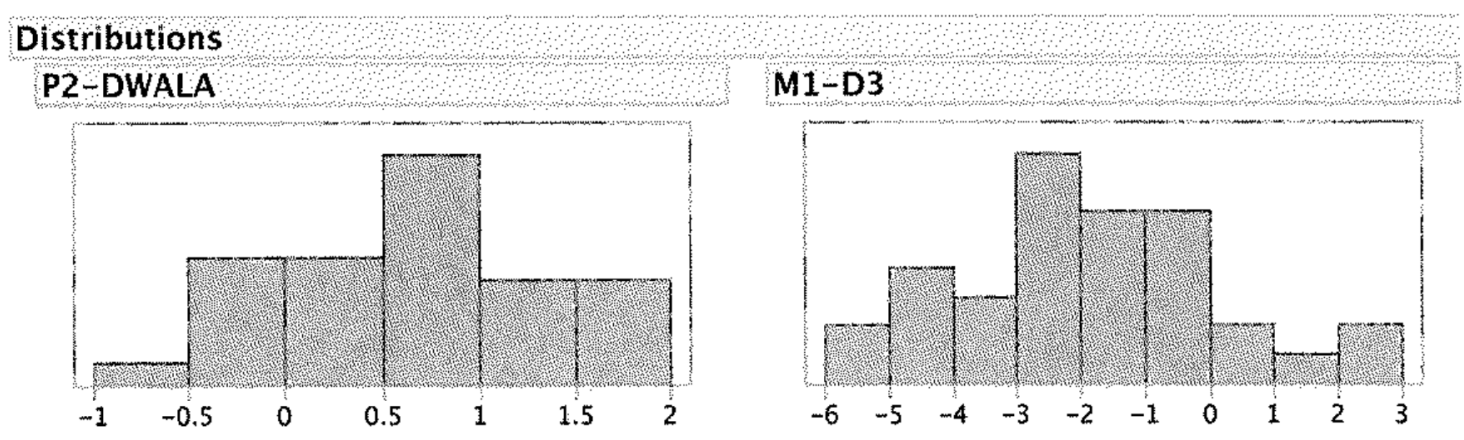

$\begin{array}{lrr}\text { Quantiles } & \\ 100.0 \% & \text { maximum } & 1.96 \\ 99.5 \% & & 1.96 \\ 97.5 \% & & 1.96 \\ 90.0 \% & & 1.695 \\ 75.0 \% & \text { quartile } & 1.13 \\ 50.0 \% & \text { median } & 0.715 \\ 25.0 \% & \text { quartile } & 0.1925 \\ 10.0 \% & & -0.11 \\ 2.5 \% & & -0.76 \\ 0.5 \% & & -0.76 \\ 0.0 \% & \text { minimum } & -0.76\end{array}$

\section{Summary Statistics \\ Mean $\quad 0.6870588$ \\ Std Dev $\quad 0.6517693$ \\ Std Err Mean $\quad 0.1117775$ \\ Upper 95\% Mean 0.9144719 \\ Lower 95\% Mean 0.4596458}

N

34

Test Mean

$\begin{array}{lr}\text { Hypothesized Value } & 0 \\ & 0.68706\end{array}$

DF 33

Std Dev $\quad 0.65177$

t Test

Test Statistic $\quad 6.1467$

Prob $>|\mathrm{t}| \mathrm{fon} \mathrm{A}^{*}$

Prob $>t \quad$ e.

Prob $<\mathrm{t} \quad 1.0000$

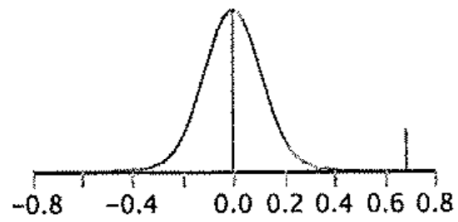

\section{Quantiles}

$\begin{array}{llr}100.0 \% & \text { maximum } & 2.4 \\ 99.5 \% & & 2.4 \\ 97.5 \% & & 2.4 \\ 90.0 \% & & 0.95 \\ 75.0 \% & \text { quartile } & -0.675 \\ 50.0 \% & \text { median } & -2.1 \\ 25.0 \% & \text { quartile } & -3.425 \\ 10.0 \% & & -4.8 \\ 2.5 \% & & -5.6 \\ 0.5 \% & & -5.6 \\ 0.0 \% & \text { minimum } & -5.6\end{array}$

Summary Statistics

Mean

$-1.997059$

Std Dev

2.0261152

Std Err Mean $\quad 0.3474759$

Upper 95\% Mean -1,290114

Lower 95\% Mean $\quad-2.704004$

N

34

\section{Test Mean}

Hypothesized Value Actual Estimate $\quad-1.9971$

DF

Std Dev

33

2.02612

Test Statistic

$-5.7473$

Prob $>|\mathrm{t}|$

Prob $>t \quad 1.0000$

Prob $<t \quad \therefore$ sob:

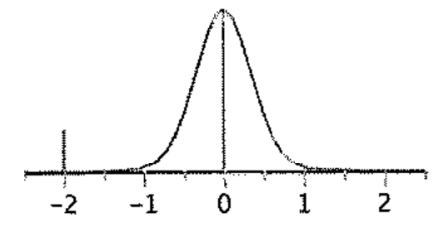



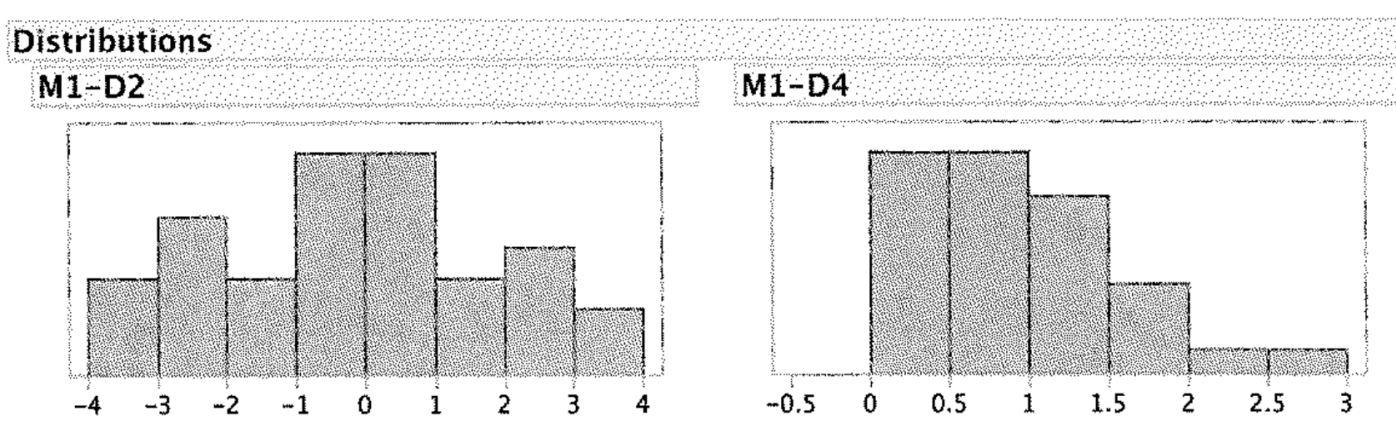

$\begin{array}{lrr}\text { Quantiles } & \\ 100.0 \% & \text { maximum } & 3.2 \\ 99.5 \% & & 3.2 \\ 97.5 \% & & 3.2 \\ 90.0 \% & & 2.8 \\ 75.0 \% & \text { quartile } & 1.025 \\ 50.0 \% & \text { median } & -0.25 \\ 25.0 \% & \text { quartile } & -2.025 \\ 10.0 \% & & -2.85 \\ 2.5 \% & & -3.9 \\ 0.5 \% & & -3.9 \\ 0.0 \% & \text { minimum } & -3.9\end{array}$

\begin{tabular}{|c|c|c|}
\hline \multicolumn{3}{|c|}{ Quantiles } \\
\hline $100.0 \%$ & maximum & 2.5 \\
\hline $99.5 \%$ & & 2.5 \\
\hline $97.5 \%$ & & 2 \\
\hline $90.0 \%$ & & 1.7 \\
\hline $75.0 \%$ & quartile & 1.325 \\
\hline $50.0 \%$ & median & 0.65 \\
\hline $25.0 \%$ & quartile & 0.4 \\
\hline $10.0 \%$ & & 0.1 \\
\hline $2.5 \%$ & & \\
\hline $0.5 \%$ & & 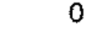 \\
\hline $0.0 \%$ & minimum & 0 \\
\hline
\end{tabular}

Summary Statistics

$\begin{array}{lr}\text { Mean } & -0.294118 \\ \text { Std Dev } & 1.9401564 \\ \text { Std Err Mean } & 0.3327341 \\ \text { Upper 95\% Mean } & 0.3828349 \\ \text { Lower 95\% Mean } & -0.97107 \\ \text { N } & 34\end{array}$

Test Mean
Hypothesized Value $\begin{array}{lr}\text { Actual Estimate } & -0.2941\end{array}$ DF 33

Std Dev $\quad 1.94016$

$t$ Test

Test Statistic $\quad-0.8839$

Prob $>|\mathrm{t}| \quad 0.3831$

Prob $>t \quad 0.8084$

Prob $<\mathrm{t} \quad 0.1916$

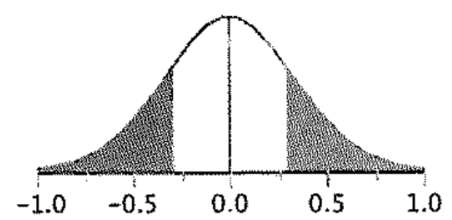

\section{Summary Statistics}

Mean $\quad 0.8647059$

Std Dev .... . 0.6461458

Std Err Mean ․ 0.1108131

Upper 95\% Mean 1.0901568

Lower 95\% Mean 0.6392549

$\mathrm{N}$

349
34

Test Mean

Hypothesized Value 0

Actual Estimate $\quad 0.86471$

DF

Std Dev

0.64615

Test Statistic Test

Prob $>|t|$

Prob $>t \quad .001$

Prob $<t \quad 1.0000$

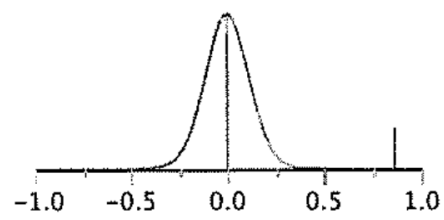




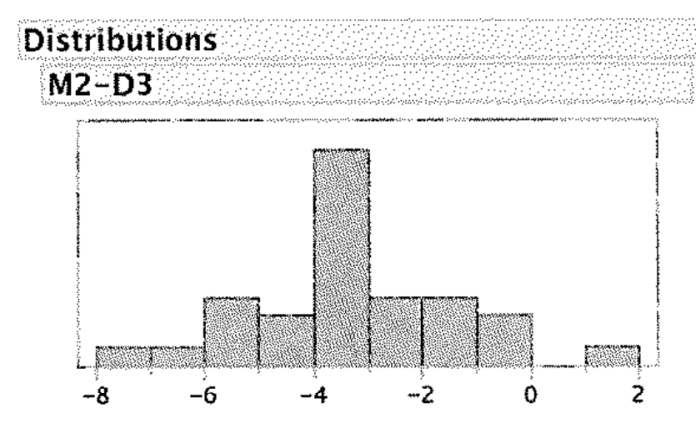

\section{M2-D1}

\begin{tabular}{|c|c|c|}
\hline \multicolumn{3}{|c|}{ Quantiles } \\
\hline $100.0 \%$ & maximum & 1.1 \\
\hline $99.5 \%$ & & 1.1 \\
\hline $97.5 \%$ & & 1.1 \\
\hline $90.0 \%$ & & -0.45 \\
\hline $75.0 \%$ & quartile & -2.15 \\
\hline $50.0 \%$ & median & -3.45 \\
\hline $25.0 \%$ & quartile & -4.125 \\
\hline $10.0 \%$ & & -5.7 \\
\hline $2.5 \%$ & & -7.7 \\
\hline $0.5 \%$ & & -7.7 \\
\hline $0.0 \%$ & minimum & -7.7 \\
\hline
\end{tabular}

Summary Statistics

Mean $\quad-3.352941$

Std Dev $\quad 1.8894019$

Std Err Mean 0.3240298

Upper 95\% Mean -2.693698

Lower 95\% Mean -4.012185

N

34

Test Mean

Hypothesized Value 0

Actual Estimate $\quad-3.3529$

DF

Std Dev

1.8894

t Test

Test Statistic $\quad-10.348$

Prob $>|t| \quad<.0601$

Prob $>\mathrm{t} \quad 1.0000$

Prob $<\mathrm{t}<000$ t

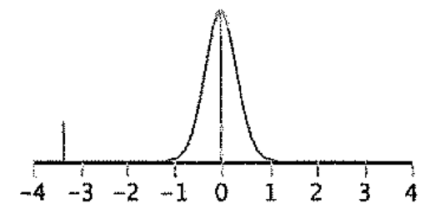

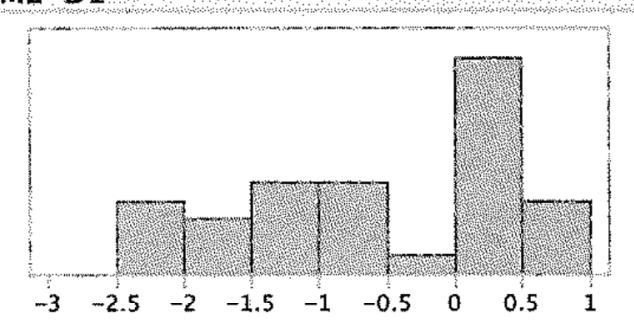

\section{Quantiles}

$\begin{array}{llr}100.0 \% & \text { maximum } & 0.9 \\ 99.5 \% & & 0.9 \\ 97.5 \% & & 0.9 \\ 90.0 \% & & 0.55 \\ 75.0 \% & \text { quartile } & 0.075 \\ 50.0 \% & \text { median } & -0.55 \\ 25.0 \% & \text { quartile } & -1.5 \\ 10.0 \% & & -2.1 \\ 2.5 \% & & -2.5 \\ 0.5 \% & & -2.5 \\ 0.0 \% & \text { minimum } & -2.5\end{array}$

\section{Summary Statistics}

$\begin{array}{lr}\text { Mean } & -0.638235 \\ \text { Std Dev } & 0.9936205 \\ \text { Std Err Mean } & 0.1704045 \\ \text { Upper 95\% Mean } & -0.291545 \\ \text { Lower 95\% Mean } & -0.984926 \\ \text { N } & 34\end{array}$

Test Mean

Hypothesized Value Actual Estimate $\quad-0.6382$

DF

33
0.99362

Std Dev

t Test

Test Statistic $\quad-3.7454$

Prob $>|t| \quad 0.0607$

Prob $>t \quad 0.9997$

Prob $<t$ : 0.0000

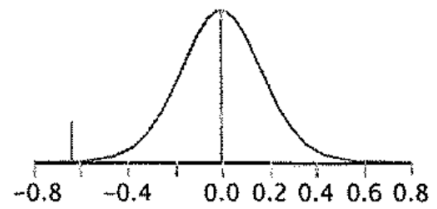



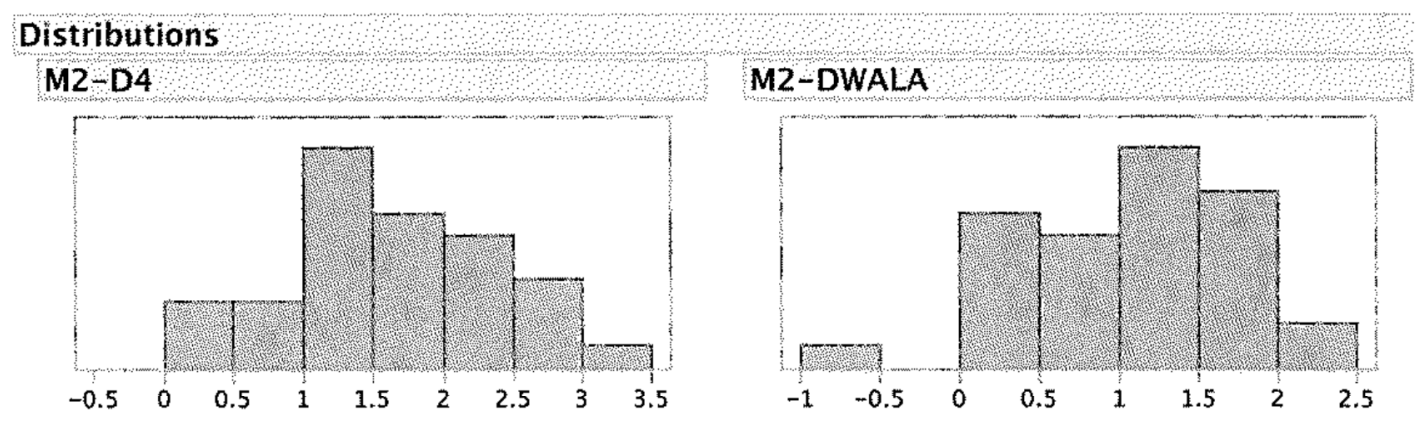

\begin{tabular}{|c|c|c|}
\hline \multicolumn{3}{|c|}{ Quantiles } \\
\hline $100.0 \%$ & maximum & 3.4 \\
\hline $99.5 \%$ & & 3 \\
\hline $97.5 \%$ & & 3.2. \\
\hline $90.0 \%$ & & 2. \\
\hline $75.0 \%$ & quartile & 2.2 \\
\hline $50.0 \%$ & median & 1.5 \\
\hline $25.0 \%$ & quartile & 1.075 \\
\hline $10.0 \%$ & & 0.4 \\
\hline $2.5 \%$ & & 0 \\
\hline $0.5 \%$ & & 0 \\
\hline $0.0 \%$ & minimum & 0 \\
\hline
\end{tabular}

\begin{tabular}{|c|c|c|}
\hline \multicolumn{3}{|c|}{ Quantiles } \\
\hline $100.0 \%$ & maximum & 2.12 \\
\hline $99.5 \%$ & & 2.12 \\
\hline $97.5 \%$ & & 2.12 \\
\hline $90.0 \%$ & & 1.87 \\
\hline $75.0 \%$ & quartile & 1.565 \\
\hline $50.0 \%$ & median & 1.065 \\
\hline $25.0 \%$ & quartile & 0.5525 \\
\hline $10.0 \%$ & & 0.28 \\
\hline $2.5 \%$ & & -0.76 \\
\hline $0.5 \%$ & & -0.76 \\
\hline $0.0 \%$ & minimum & -0.76 \\
\hline
\end{tabular}

\section{Summary Statistics}

Mean $\quad 1.5611765$

Std Dev … $\quad 0.8188527$

Std Err Mean . $\quad 0.1404321$

Upper 95\% Mean 1.8468877

Lower 95\% Mean 1.2754652

$\mathrm{N}$

Test Mean

$\begin{array}{lr}\text { Hypothesized Value } & 0 \\ \text { Actual Estimate } & 1.56118\end{array}$

DF

33
885

Std Dev

0.81885

Test Statistic 11.1170

Prob $>|\mathrm{t}|$

Prob $>t \quad ., 000$

Prob $<\mathrm{t} \quad 1.0000$

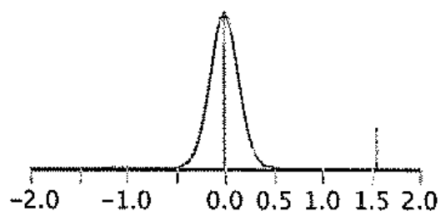

\section{Summary Statistics}

Mean $\quad 1.0408824$

Std Dev : $\quad 0.6409007$

Std Err Mean 0.1099136

Upper 95\% Mean 1.2645032

Lower $95 \%$ Mean 0.8172615

$\mathrm{N} \quad 34$

$\begin{array}{lc}\text { Test Mean } \\ \text { Hypothesized Value } & 0\end{array}$

$\begin{array}{lr}\text { Hypothesized Value } & \\ \text { Actual Estimate } & 1.04088\end{array}$

DF 33

Std Dev $\quad 0.6409$

Test Statistic 9.4700

$\begin{array}{ll}\text { Prob }>|\mathrm{t}| & 9.4700 \\ \text { Prob }>\mathrm{t} & .001\end{array}$

Prob $>t \quad 0.0 \%$

Prob $<\mathrm{t} \quad 1.0000$

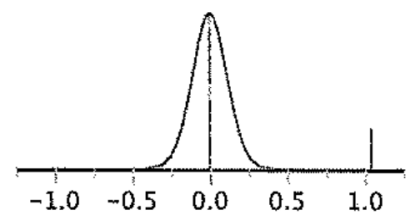




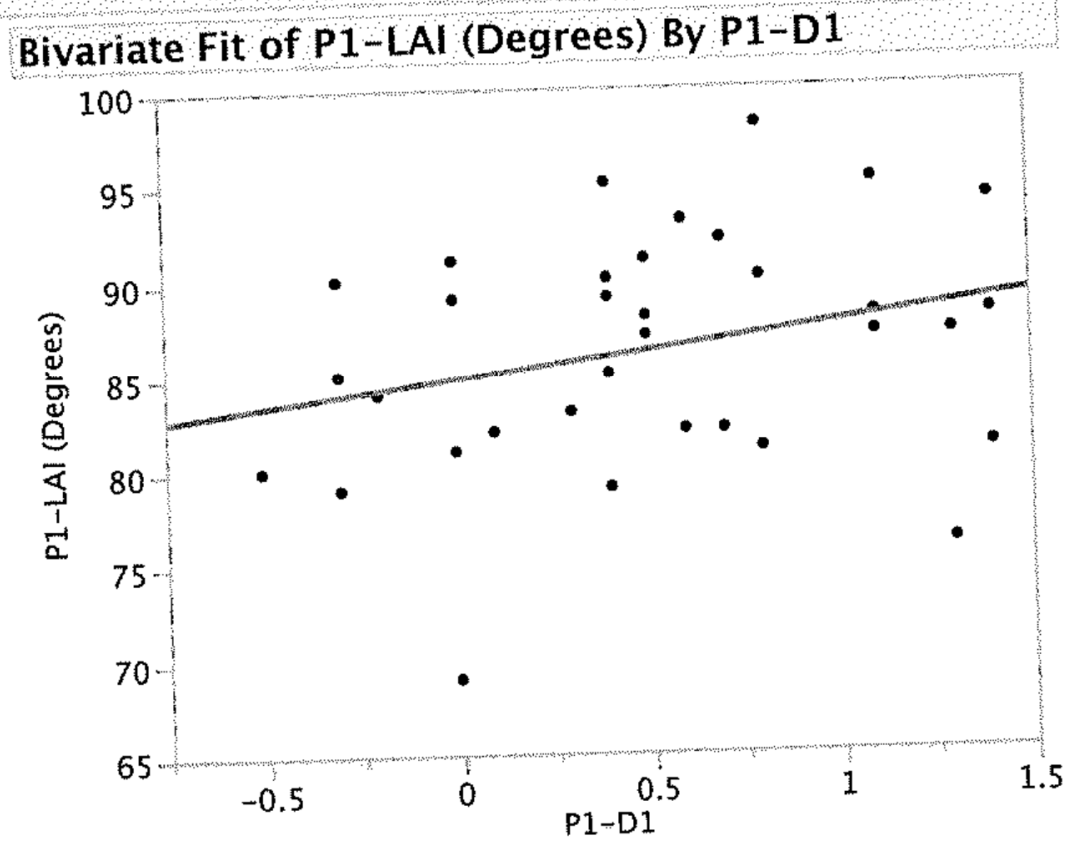

Linear Fit

Linear Fit

P1-LAl (Degrees) $=84.776339+2.7933597 * P 1-D 1$

Summary of Fit

RSquare

RSquare Adj

0.061488

0.03216

Root Mean Square Error

6.044035

Mean of Response

86.20588

Observations (or Sum Wgts)

34

\section{Analysis of Variance}

$\begin{array}{lrrrr} & & \text { Sum of } & & \\ \text { Source } & \text { DF } & \text { Squares } & \text { Mean Square } & \text { F Ratio } \\ \text { Model } & 1 & 76.5874 & 76.5874 & 2.0965 \\ \text { Error } & 32 & 1168.9715 & 36.5304 & \text { Prob }>\text { F } \\ \text { C. Total } & 33 & 1245.5588 & & 0.1574\end{array}$

\section{Parameter Estimates}

$\begin{array}{lrlrl}\text { Term } & \text { Estimate } & \text { Std Error } & \text { t Ratio } & \text { Prob }>|t| \\ \text { Intercept } & 84.776339 & 1.431491 & 59.22 & 6000 \mid \\ \text { P1-D1 } & 2.7933597 & 1.929191 & 1.45 & 0.1574\end{array}$




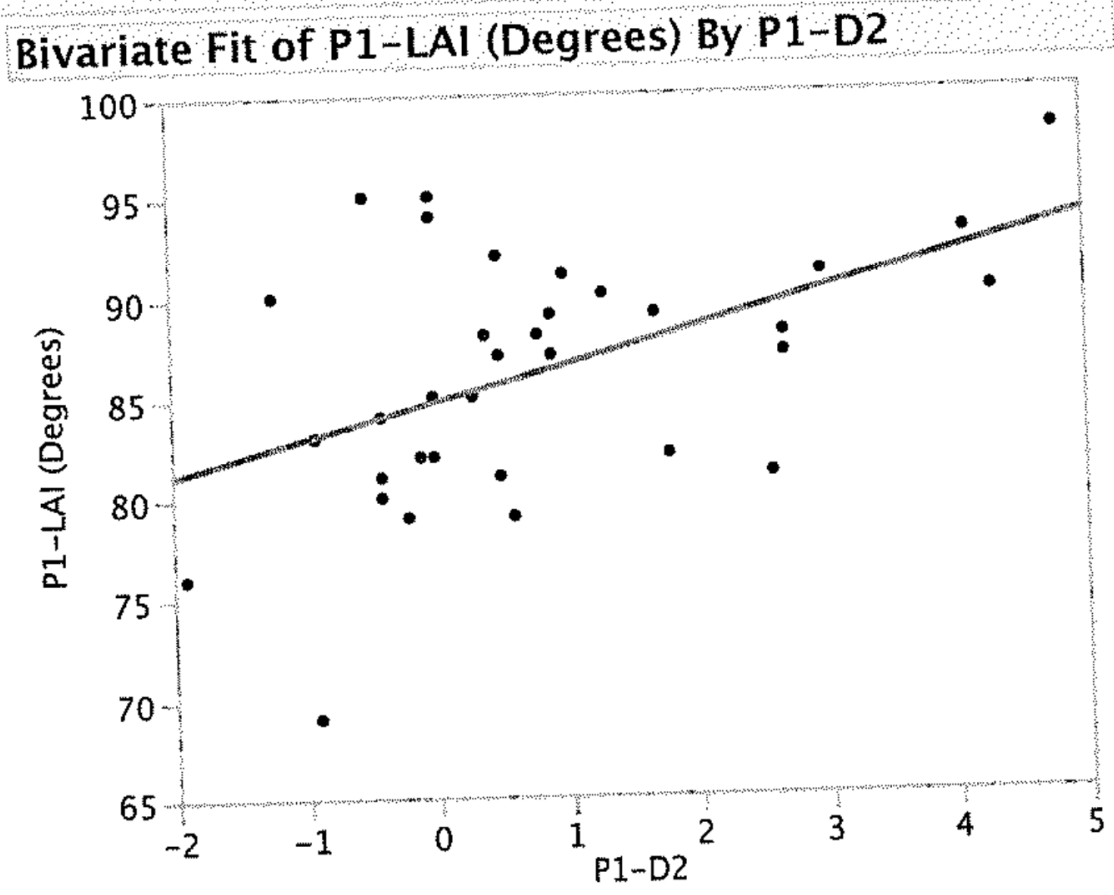

- Linear Fit

Linear Fit

P1-LAl (Degrees) $=84.691042+1.8071779 * P 1-D 2$

Summary of Fit

RSquare

RSquare Adj

Root Mean Square Error

Mean of Response

0.222034

0.197723

5.502846

86.20588

Observations (or Sum Wgts)

34

\section{Analysis of Variance}

$\begin{array}{lrrrr}\text { Source } & \text { DF } & \begin{array}{r}\text { Sum of } \\ \text { Squares }\end{array} & \text { Mean Square } & \text { F Ratio } \\ \text { Model } & 1 & 276.5567 & 276.557 & 9.1329 \\ \text { Error } & 32 & 969.0021 & 30.281 & \text { Prob > F } \\ \text { C. Total } & 33 & 1245.5588 & & 0.0049\end{array}$

\section{Parameter Estimates}

$\begin{array}{lrlrr}\text { Term } & \text { Estimate } & \text { Std Error } & \text { t Ratio } & \text { Prob }>|\mathbf{t}| \\ \text { Intercept } & 84.691042 & 1.068591 & 79.25 & 2.000 \\ \text { P1-D2 } & 1.8071779 & 0.597993 & 3.02 & 0.00 \% \mathrm{~g}\end{array}$




\section{Fit Group}

Bivariate Fit of P1 - LAl (Degrees) By P1-D3

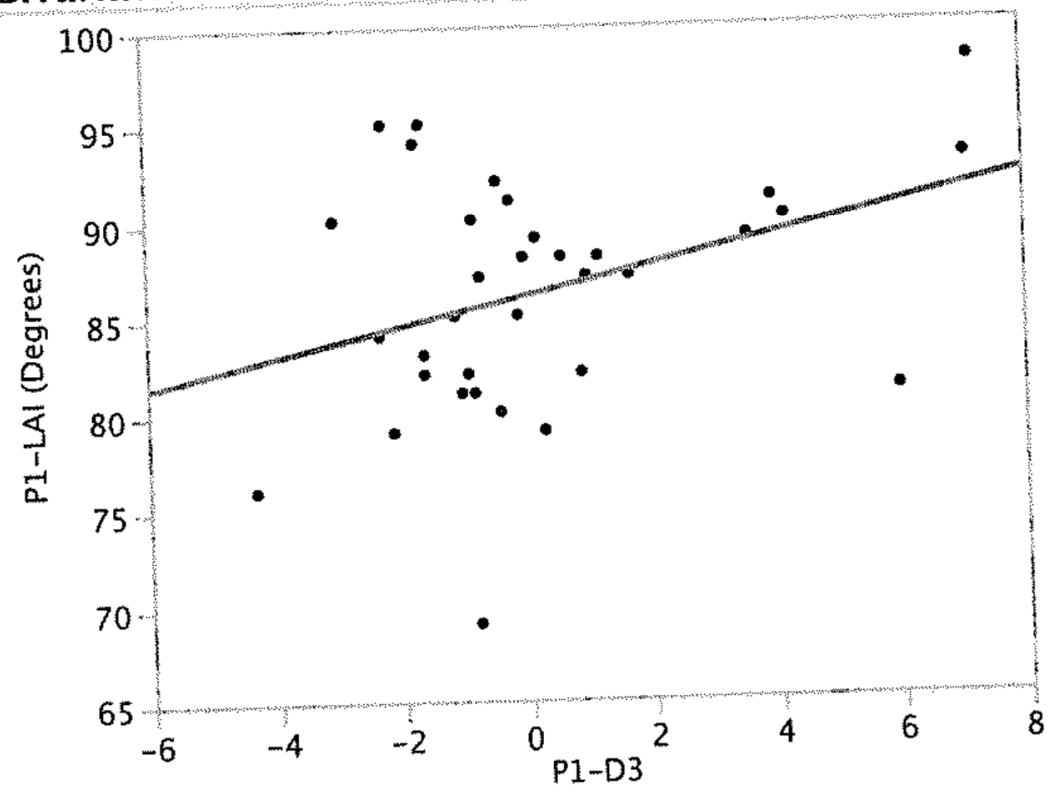

\begin{tabular}{|c|c|c|c|c|c|}
\hline \multicolumn{6}{|c|}{ Linear Fit } \\
\hline \multicolumn{6}{|c|}{ Linear Fit } \\
\hline \multicolumn{6}{|c|}{ P1-LAl (Degrees) $=85.971592+0.7659494 * P 1-D 3$} \\
\hline \multicolumn{6}{|c|}{ Summary of Fit } \\
\hline \multicolumn{4}{|c|}{$\begin{array}{l}\text { RSquare } \\
\text { RSquare Adj } \\
\text { Root Mean Square Error } \\
\text { Mean of Response } \\
\text { Observations (or Sum Wgts) }\end{array}$} & $\begin{array}{r}6199 \\
8858 \\
6522 \\
0588 \\
34\end{array}$ & \\
\hline \multicolumn{6}{|c|}{ Analysis of Variance } \\
\hline $\begin{array}{l}\text { Source } \\
\text { Model }\end{array}$ & $\begin{array}{r}\text { DF } \\
1\end{array}$ & & $\begin{array}{l}\text { Sum of } \\
\text { Squares } \\
44.7329\end{array}$ & $\begin{array}{r}\text { Tean Square } \\
144.733\end{array}$ & $\begin{array}{ll}\text { e } & \text { F Ratio } \\
3 & 4.2073\end{array}$ \\
\hline Error & 32 & & 0.8259 & 34.401 & 1 Prob $>F$ \\
\hline C. Total & 33 & & 45.5588 & & 0.0485 \\
\hline \multicolumn{6}{|c|}{ Parameter Estimates } \\
\hline $\begin{array}{l}\text { Term } \\
\text { intercept } \\
\text { P1-D3 }\end{array}$ & $\begin{array}{r}\text { Estin } \\
85.971 \\
0.7659\end{array}$ & $\begin{array}{l}\text { late } \\
592 \\
494\end{array}$ & $\begin{array}{l}\text { Std Error } \\
1.012342 \\
0.373423\end{array}$ & $\begin{array}{r}\text { t Ratio } \mathrm{Pr} \\
84.92 \\
2.05\end{array}$ & $\begin{array}{l}\text { Prob }>|t| \\
.000 \\
.0 \% 85^{2}\end{array}$ \\
\hline
\end{tabular}




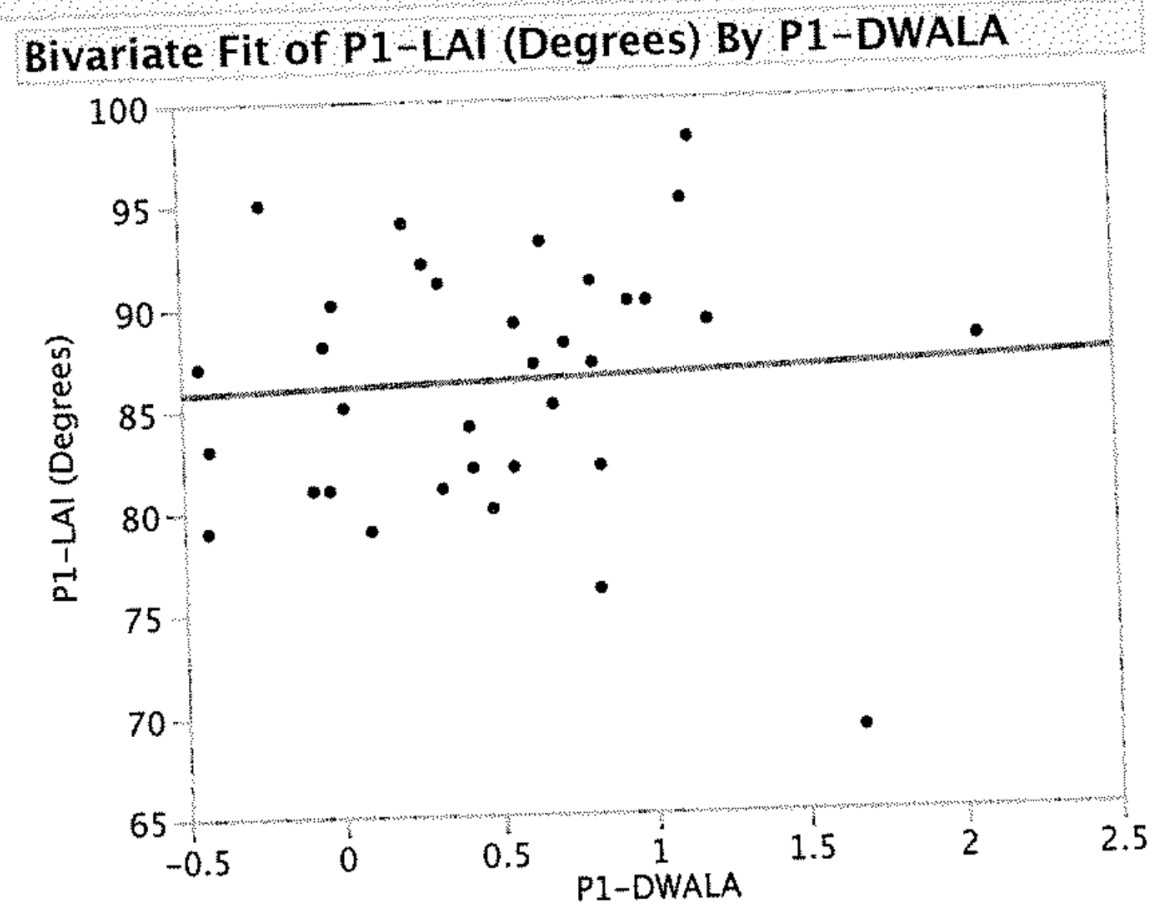

Linear Fit

Linear Fit

P1-LAl (Degrees) $=85.960273+0.4835383 * \mathrm{P} 1-$ DWALA

Summary of Fit

RSquare

0.002067

RSquare Adj

$-0.02912$

Root Mean Square Error

6.232436

Mean of Response

86.20588

Observations (or Sum Wgts)

34

Analysis of Variance

$\begin{array}{lrrrr}\text { Source } & \text { DF } & \begin{array}{r}\text { Sum of } \\ \text { Squares }\end{array} & \text { Mean Square } & \text { F Ratio } \\ \text { Model } & 1 & 2.5746 & 2.5746 & 0.0663 \\ \text { Error } & 32 & 1242.9843 & 38.8433 & \text { Prob > F } \\ \text { C. Total } & 33 & 1245.5588 & & 0.7985\end{array}$

\section{Parameter Estimates}

$\begin{array}{lrrrr}\text { Term } & \text { Estimate } & \text { Std Error } & \text { t Ratio } & \text { Prob }>|\mathbf{t}| \\ \text { Intercept } & 85.960273 & 1.432681 & 60.00 & <.000 \\ \text { P1-DWALA } & 0.4835383 & 1.878181 & 0.26 & 0.7985\end{array}$




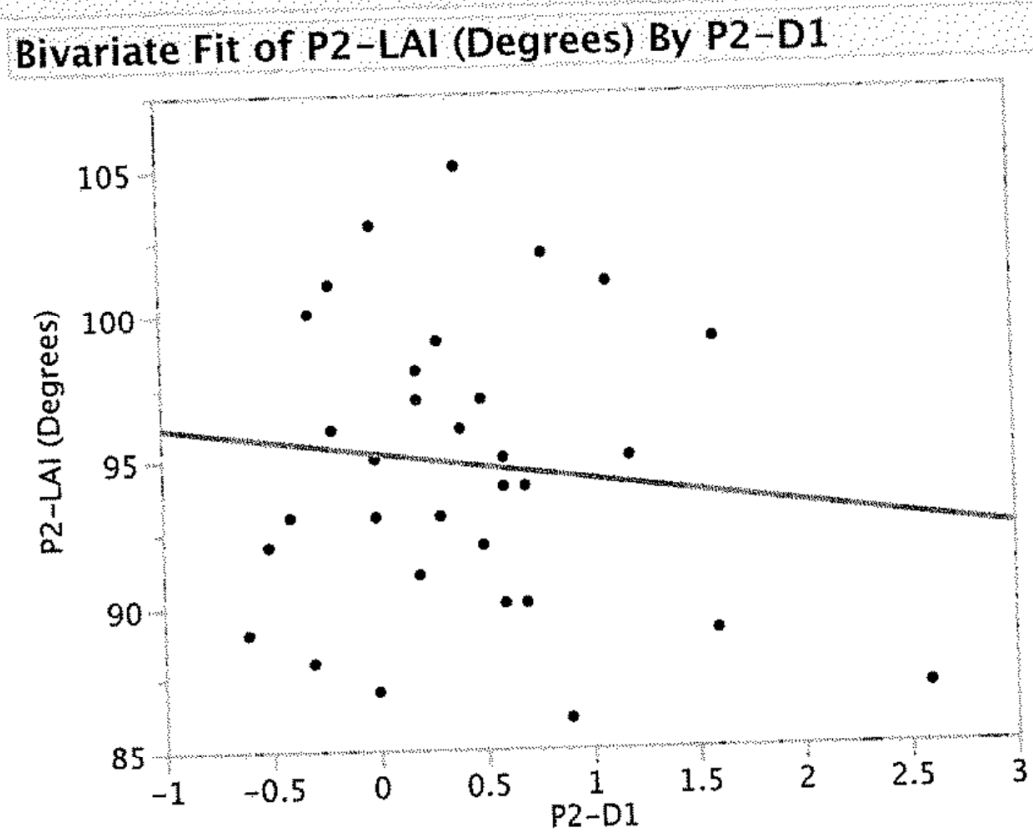

Linear Fit

Linear Fit

P2-LAl (Degrees) $=95.173699-0.9218396 *$ P2-D1

Summary of Fit

RSquare

RSquare Adj

Root Mean Square Error

Mean of Response

$-0.01545$

Observations (or Sum Wgts)

94.79412

Analysis of Variance

\begin{tabular}{|c|c|c|c|c|}
\hline $\begin{array}{l}\text { Source } \\
\text { Model }\end{array}$ & $\begin{array}{r}\text { DF } \\
1\end{array}$ & $\begin{array}{r}\text { Sum of } \\
\text { Squares } \\
12.36892\end{array}$ & $\begin{array}{r}\text { Mean Square } \\
12.3689\end{array}$ & $\begin{array}{l}\text { F Ratio } \\
0.4977\end{array}$ \\
\hline I. & 32 & 795.18990 & 24.8497 & Prob $>F$ \\
\hline C. Total & 33 & 807.55882 & & 0.4856 \\
\hline
\end{tabular}

\section{Parameter Estimates}

$\begin{array}{lrlrr}\text { Term } & \text { Estimate } & \text { Std Error } & \text { t Ratio } & \text { Prob }>|t| \\ \text { Intercept } & 95.173699 & 1.010119 & 94.22 & 6.001 \\ \text { P2-D1 } & -0.92184 & 1.306622 & -0.71 & 0.4856\end{array}$


Bivariate Fit of P2 - LAI (Degrees) By P2-D2

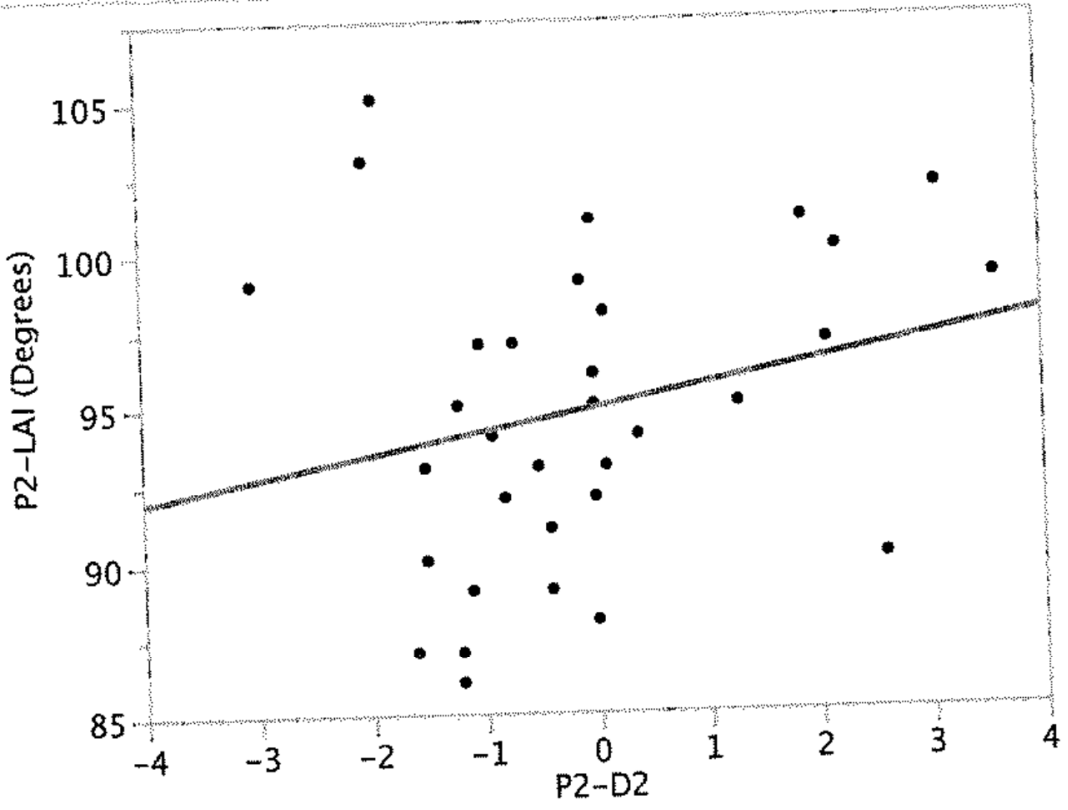

Linear Fit

Linear Fit
P2-LAl (Degrees) $=94.872365$
Summary of Fit
RSquare

Analysis of Variance

\begin{tabular}{|c|c|c|c|c|}
\hline $\begin{array}{l}\text { Source } \\
\text { Model }\end{array}$ & $\begin{array}{r}\text { DF } \\
1\end{array}$ & $\begin{array}{r}\text { Sum of } \\
\text { Squares } \\
41.72314\end{array}$ & $\begin{array}{r}\text { Mean Square } \\
41.7231\end{array}$ & $\begin{array}{l}\text { F Ratio } \\
1.7434\end{array}$ \\
\hline Error & 32 & 765.83568 & 23.9324 & Prob $>F$ \\
\hline C. Total & 33 & 807.55882 & & 0.1961 \\
\hline
\end{tabular}

\section{Parameter Estimates}

\begin{tabular}{lrrrr|} 
Term & Estimate & Std Error & t Ratio & Prob $>|t|$ \\
Intercept & 94.872365 & 0.841074 & 112.80 & 0.0001 \\
P2-D2 & 0.7390012 & 0.559692 & 1.32 & 0.1961
\end{tabular}




\section{Fit Group}

Bivariate Fit of P2 - LAl (Degrees) By P2-D3

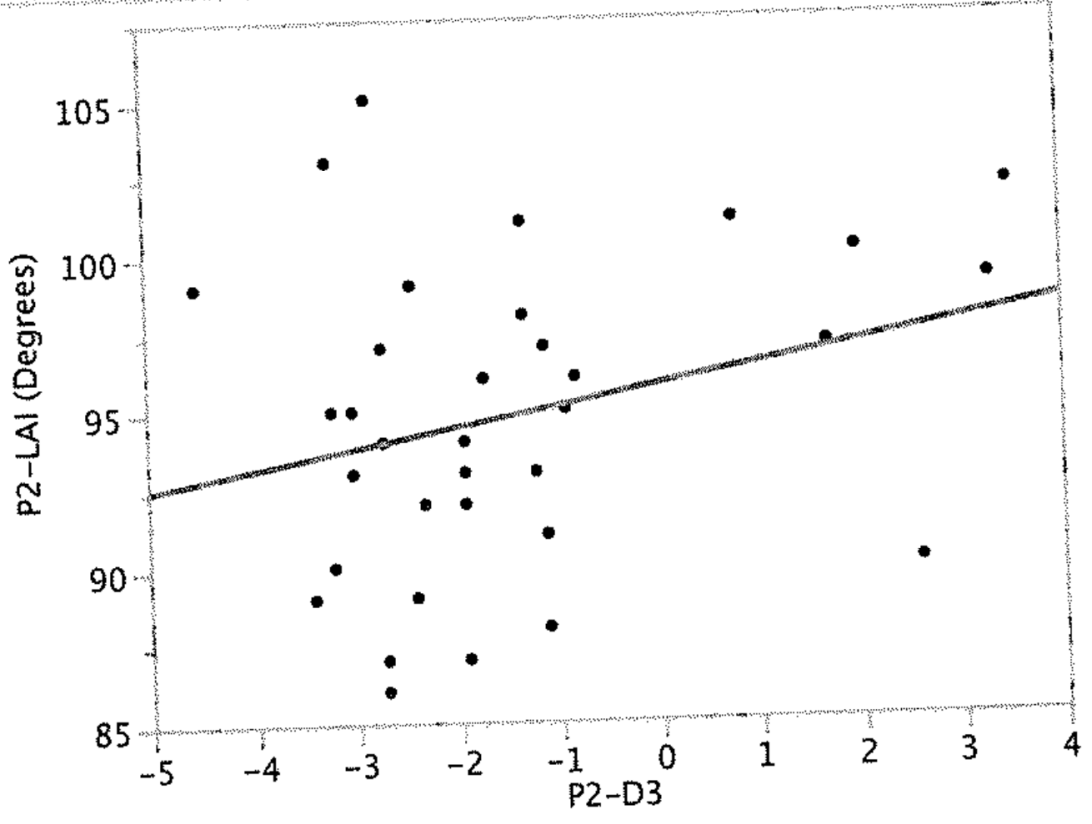

Linear Fit

Linear Fit

P2-LAl (Degrees) $=95.705948+0.6405422 * P 2-D 3$

Summary of Fit

RSquare

RSquare Adj

Root Mean Square Error

0.036916

Mean of Response

4.854698

Observations (or Sum Wgts)

94.79412

Analysis of Variance

Sum of

Source DF Squares Mean Square F Ratio

Model

I 53.37977

53.3798

2.2649

Error

$32 \quad 754.17905$

23.5681

Prob $>$ F

C. Total

$33 \quad 807.55882$

0.1421

\section{Parameter Estimates}

Term Estimate Std Error t Ratio Prob $>|t|$

Intercept $95.705948 \quad 1.029695 \quad 92.95 \quad<.0001$

$\begin{array}{lllll}\text { P2-D3 } & 0.6405422 & 0.42562 & 1.50 & 0.1421\end{array}$ 


\section{Bivariate Fit of P2 - LAI (Degrees) By P2-DWALA}

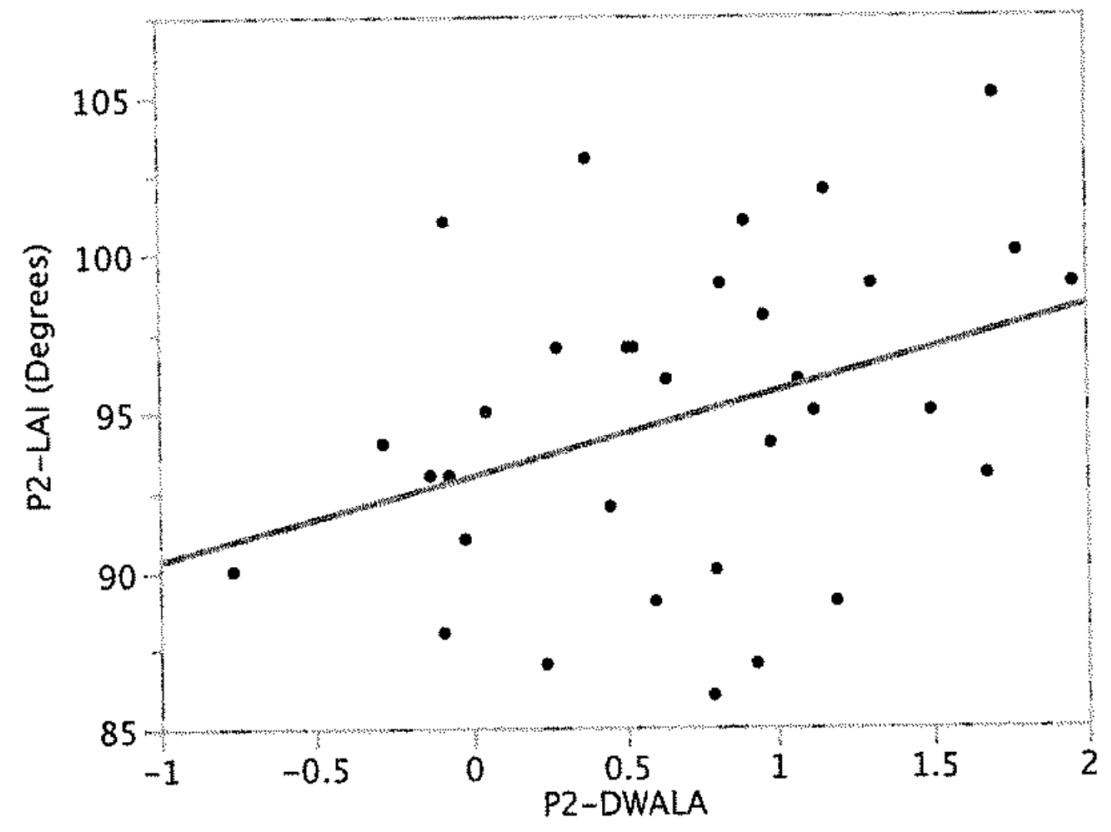

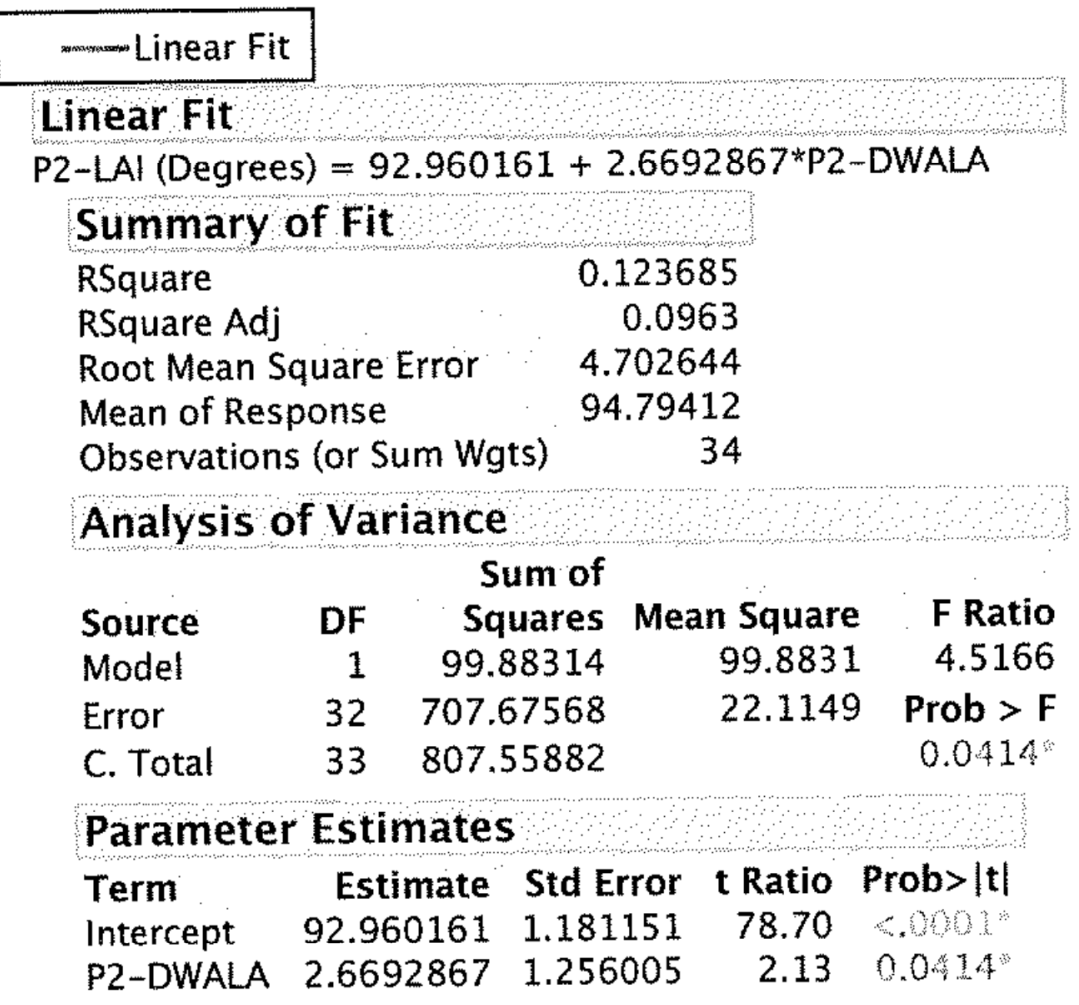




\section{Bivariate Fit of M1 - LAl (Degrees) By M1-D1}

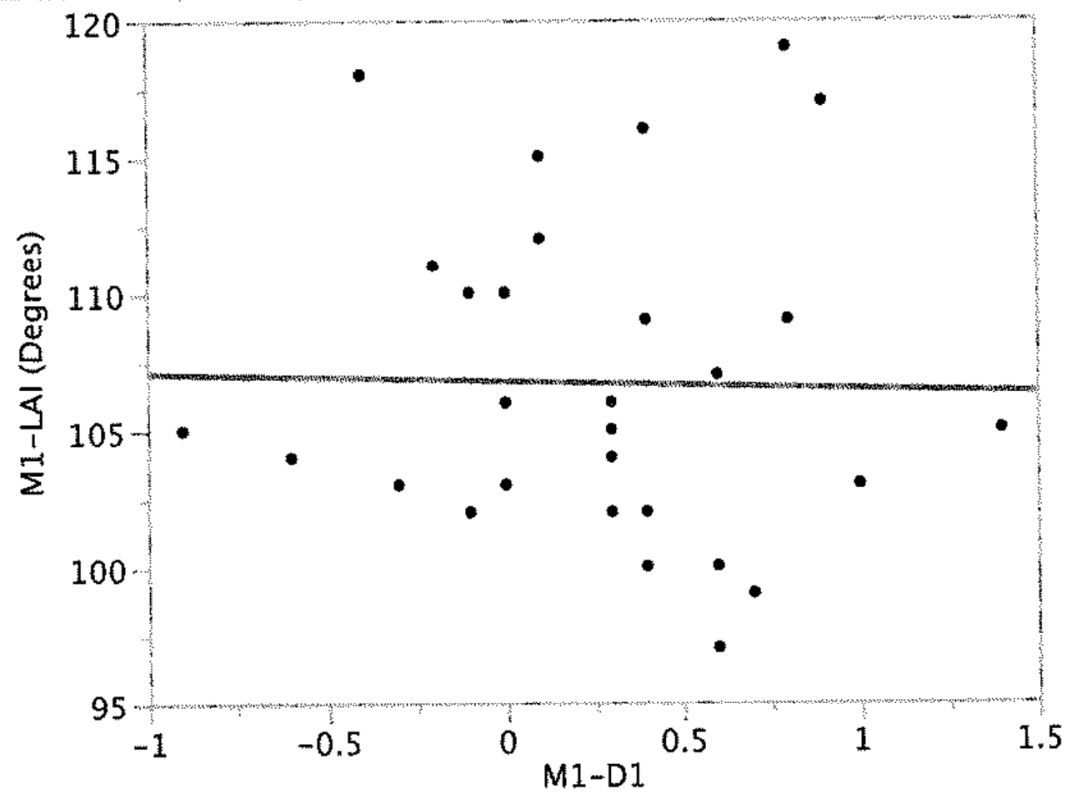

\begin{tabular}{|c|c|c|c|c|}
\hline \multicolumn{5}{|c|}{ Linear Fit } \\
\hline \multicolumn{5}{|c|}{ Linear Fit } \\
\hline \multicolumn{5}{|c|}{ M1-LAl (Degrees) $=106.77137-0.3049918 * \mathrm{M} 1-\mathrm{D} 1$} \\
\hline \multicolumn{5}{|c|}{ Summary of Fit } \\
\hline $\begin{array}{l}\text { RSquare } \\
\text { RSquare } \\
\text { Root Me } \\
\text { Mean of } \\
\text { Observat }\end{array}$ & $\begin{array}{l}\text { Uare } \\
\text { onse } \\
\text { (or S }\end{array}$ & 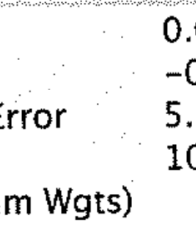 & $\begin{array}{r}000721 \\
.03051 \\
690756 \\
6.7059 \\
34\end{array}$ & \\
\hline \multicolumn{5}{|c|}{ Analysis of Variance } \\
\hline $\begin{array}{l}\text { Source } \\
\text { Model }\end{array}$ & $\begin{array}{r}\text { DF } \\
1\end{array}$ & $\begin{array}{r}\text { Sum of } \\
\text { Squares } \\
0.7481\end{array}$ & $\begin{array}{r}\text { Mean Square } \\
0.7481\end{array}$ & $\begin{array}{r}\text { Fatio } \\
0.0231\end{array}$ \\
\hline Error & 32 & 1036.3107 & 32.3847 & Prob $>F$ \\
\hline C. Total & 33 & 1037.0588 & & 0.8801 \\
\hline
\end{tabular}

\section{Parameter Estimates}

Term Estimate Std Error t Ratio Prob $>|\mathbf{t}|$ $\begin{array}{lllll}\text { Intercept } & 106.77137 & 1.066824 & 100.08 & 6.000 !\end{array}$

$\begin{array}{lllll}\text { M1-D1 } & -0.304992 & 2.006645 & -0.15 & 0.8801\end{array}$




\section{Bivariate Fit of M1-LAl (Degrees) By M1-D2}

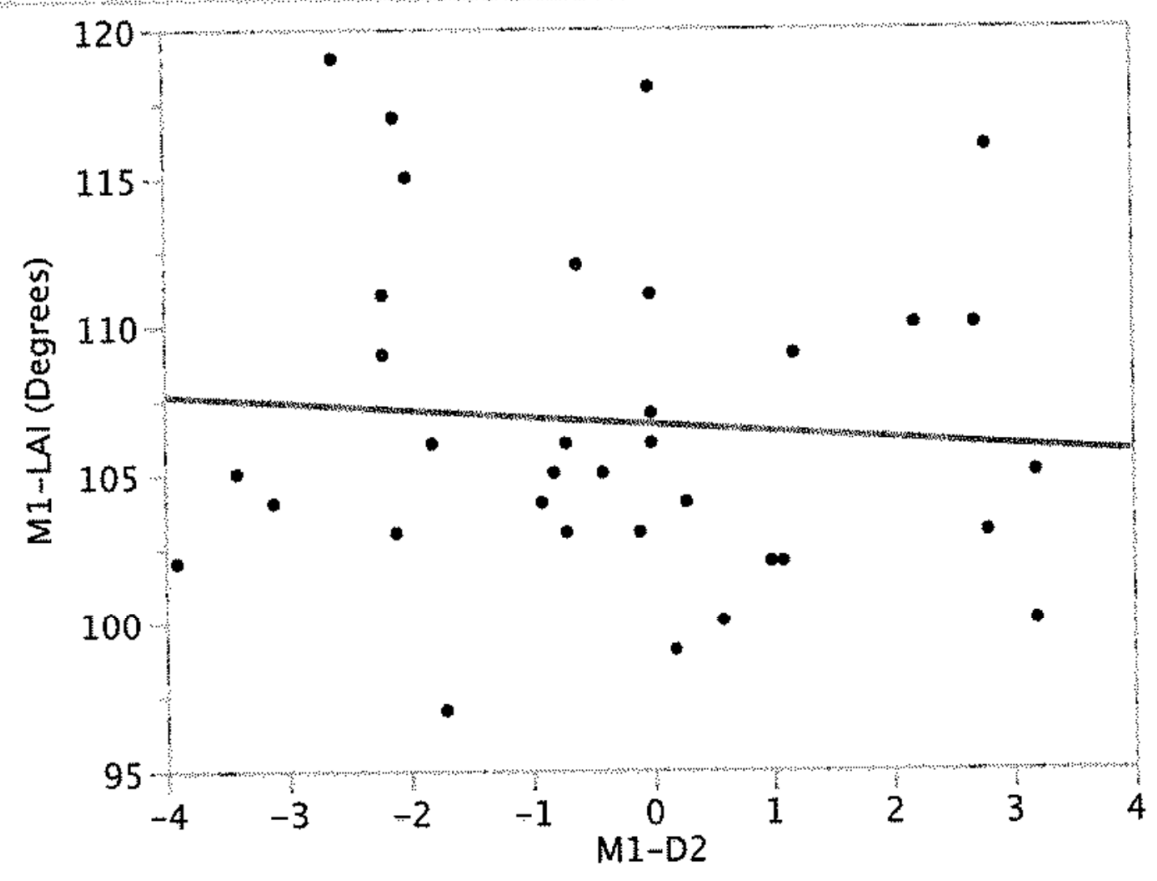

\footnotetext{
Linear Fit

Linear Fit

M1-LAl (Degrees) $=106.63381-0.2450609^{*} \mathrm{M} 1-\mathrm{D} 2$

Summary of Fit

RSquare

0.007193

RSquare Adj

Root Mean Square Error

$-0.02383$

Mean of Response

5.672298

106.7059

Observations (or Sum Wgts)

34

\section{Analysis of Variance}

\begin{tabular}{lrrrr} 
Source & DF & $\begin{array}{r}\text { Sum of } \\
\text { Squares }\end{array}$ & Mean Square & F Ratio \\
Model & 1 & 7.4599 & 7.4599 & 0.2319 \\
Error & 32 & 1029.5989 & 32.1750 & $\begin{array}{c}\text { Prob > F } \\
\text { C. Total }\end{array}$ \\
\hline 3 & 1037.0588 & & 0.6334
\end{tabular}

\section{Parameter Estimates}

$\begin{array}{lrrrr}\text { Term } & \text { Estimate } & \text { Std Error } & \text { t Ratio } & \text { Prob> }|\mathbf{t}| \\ \text { Intercept } & 106.63381 & 0.98424 & 108.34 & 6.000 \\ \text { M1-D2 } & -0.245061 & 0.508939 & -0.48 & 0.6334\end{array}$
}




\section{Fit Group}

Bivariate Fit of M1-LAl (Degrees) By M1-D3

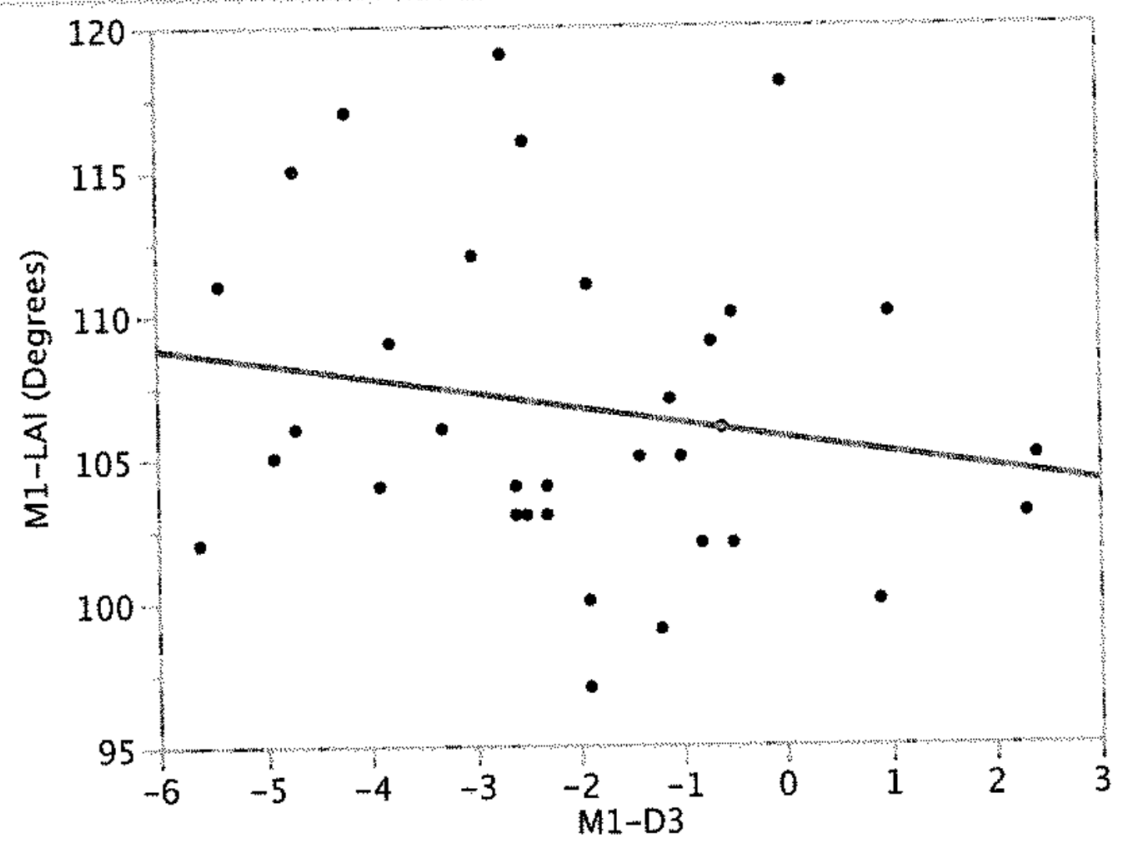

Linear Fit

\section{Linear Fit}

M1-LAl (Degrees) $=105.66113-0.5231471 * M 1-D 3$

Summary of Fit

RSquare

0.035751

RSquare Adj

0.005618

Root Mean Square Error

Mean of Response

5.590123

106.7059

Observations (or Sum Wgts)

Analysis of Variance

\begin{tabular}{|c|c|c|c|c|}
\hline ut & $\begin{array}{r}\text { DF } \\
1\end{array}$ & $\begin{array}{r}\text { Sum of } \\
\text { Squares } \\
37.0757\end{array}$ & $\begin{array}{r}\text { Mean Square } \\
37.0757\end{array}$ & $\begin{array}{l}\text { F Ratio } \\
1.1864\end{array}$ \\
\hline & 32 & 999.9831 & 31.2495 & Prob $>F$ \\
\hline & 33 & 1037.0588 & & 0.2842 \\
\hline
\end{tabular}

\section{Parameter Estimates}

$\begin{array}{lrlrl}\text { Term } & \text { Estimate } & \text { Std Error } & \text { t Ratio } & \text { Prob }>|t| \\ \text { Intercept } & 105.66113 & 1.356131 & 77.91 & <.000 \\ \text { M1-D3 } & -0.523147 & 0.480286 & -1.09 & 0.2842\end{array}$




\section{Bivariate Fit of M1-LAI (Degrees) By M1-DWALA}

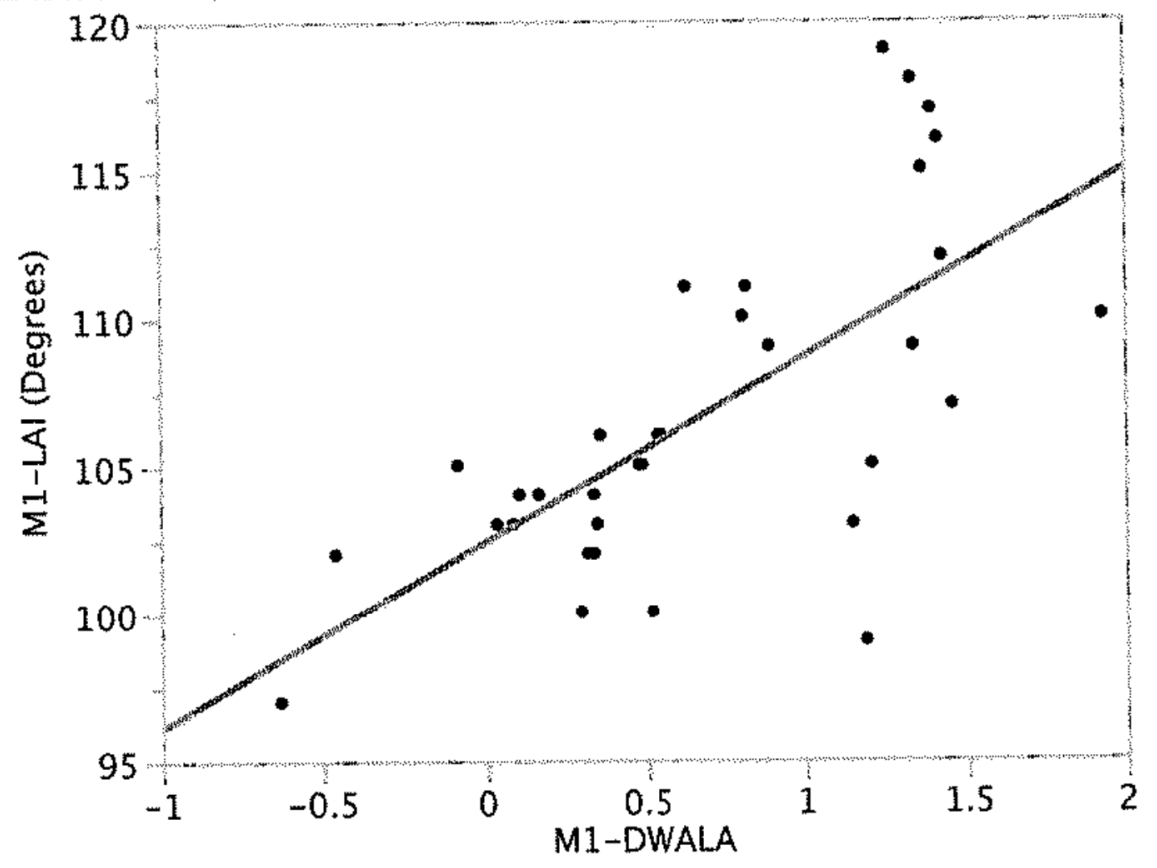

Linear Fit

Linear Fit M1-LAI (Degrees) $=102.36535+6.2852626 * M 1-D W A L A$

Summary of Fit

RSquare

RSquare Adj

Root Mean Square Error

Mean of Response

Observations (or Sum Wgts)
0.461494

0.444666

4.177551

106.7059

Analysis of Variance

$\begin{array}{lrrrr}\text { Source } & \text { DF } & \begin{array}{r}\text { Sum of } \\ \text { Squares }\end{array} & \text { Mean Square } & \text { F Ratio } \\ \text { Model } & 1 & 478.5969 & 478.597 & 27.4237 \\ \text { Error } & 32 & 558.4620 & 17.452 & \text { Prob > F } \\ \text { C. Total } & 33 & 1037.0588 & & <\text { ropt: }\end{array}$

\section{Parameter Estimates}

$\begin{array}{lrrrrr}\text { Term } & \text { Estimate } & \text { Std Error } & \text { t Ratio } & \text { Prob }>|t| \\ \text { Intercept } & 102.36535 & 1.09558 & 93.43 & <.0001 \\ \text { M1-DWALA } & 6.2852626 & 1.200218 & 5.24 & <.0001\end{array}$




\section{Bivariate Fit of M2-LAl (Degrees) By M2-D1}

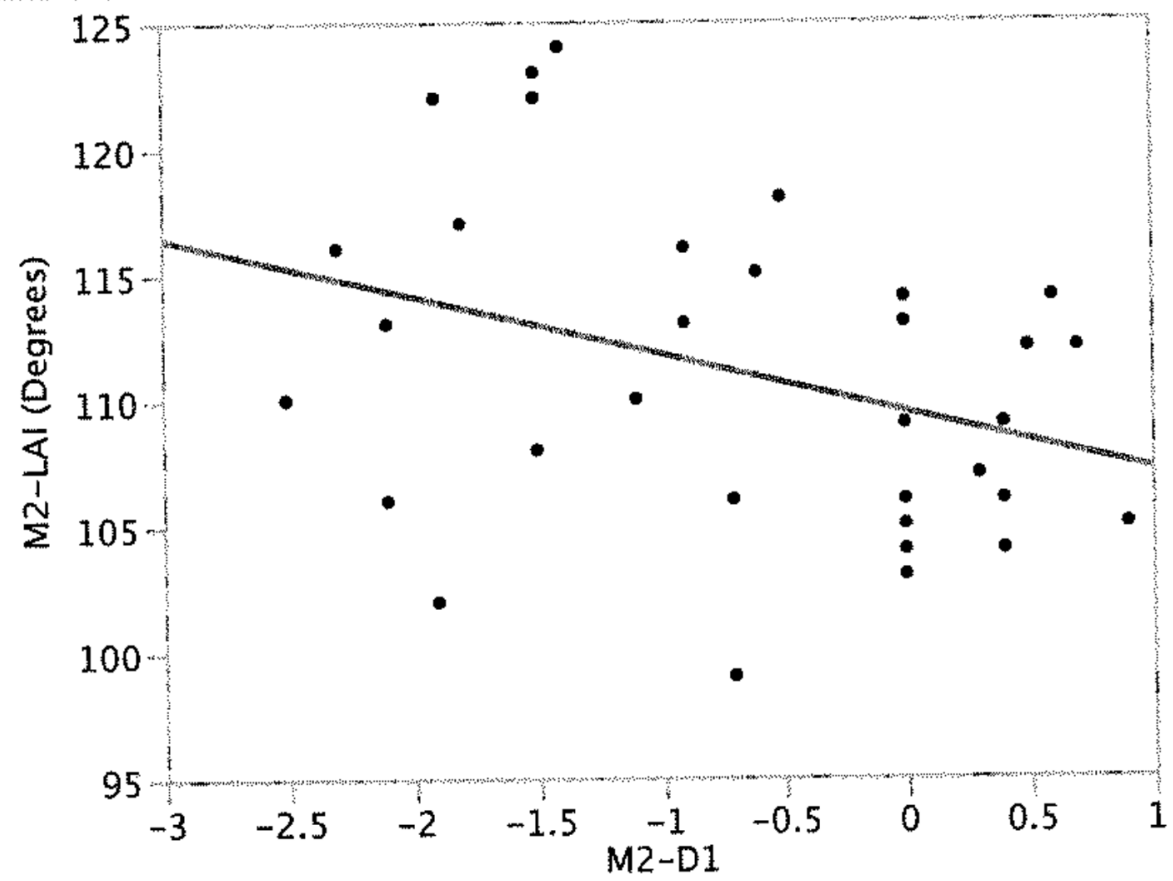

-Linear Fit

\section{Linear Fit}

M2-LAl (Degrees) $=109.4685-2.3074215^{*} \mathrm{M} 2-\mathrm{D} 1$

Summary of Fit

$\begin{array}{lr}\text { RSquare } & 0.12985 \\ \text { RSquare Adj } & 0.102657 \\ \text { Root Mean Square Error } & 6.027071 \\ \text { Mean of Response } & 110.9412 \\ \text { Observations (or Sum Wgts) } & 34\end{array}$

Analysis of Variance

Sum of

Source DF Squares Mean Square F Ratio

$\begin{array}{lllll}\text { Model } & 1 & 173.4638 & 173.464 & 4.7753\end{array}$

$\begin{array}{lllll}\text { Error } & 32 & 1162.4185 & 36.326 & \text { Prob }>\text { F }\end{array}$

$\begin{array}{llll}\text { C. Total } & 33 & 1335.8824 & 0.0363\end{array}$

\section{Parameter Estimates}

$\begin{array}{lrlrr}\text { Term } & \text { Estimate } & \text { Std Error } & \text { t Ratio } & \text { Prob }>|t| \\ \text { Intercept } & 109.4685 & 1.233925 & 88.72 & 6.0001 \\ \text { M2-D1 } & -2.307421 & 1.055915 & -2.19 & 0.0563\end{array}$




\section{Bivariate Fit of M2 - LAl (Degrees) By M2-D2}

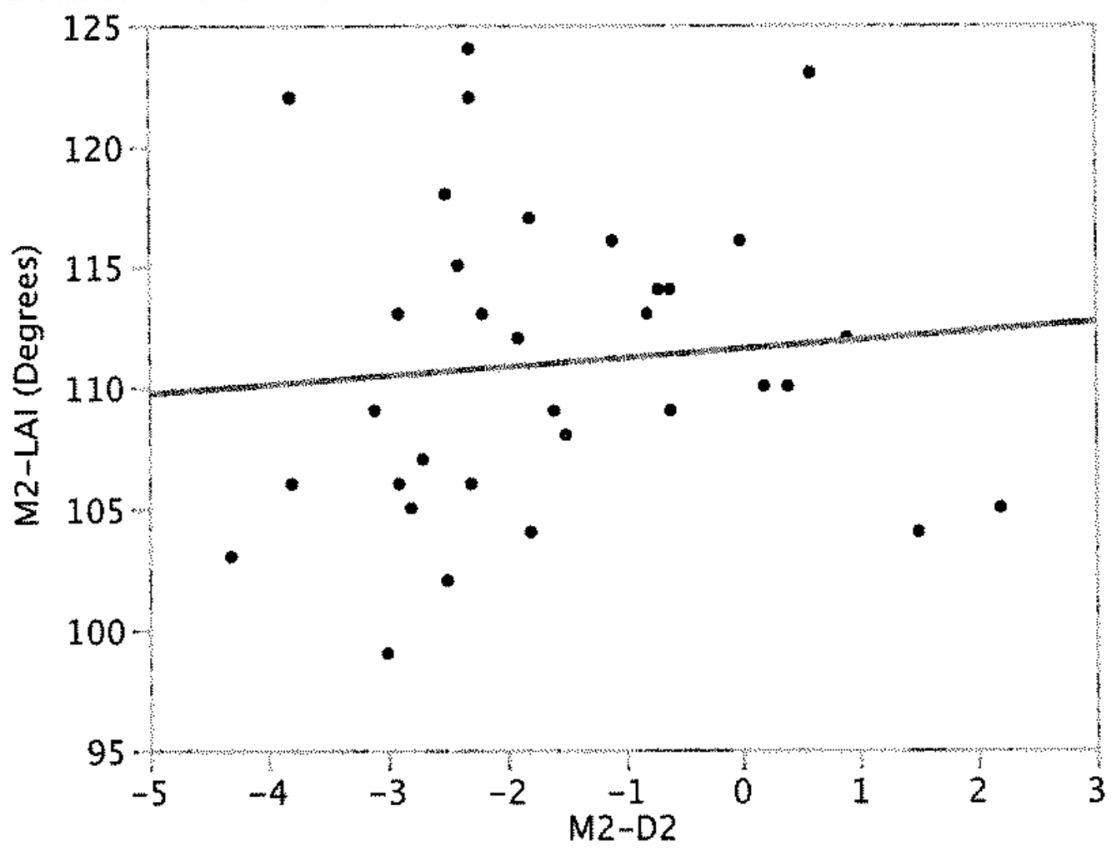

Linear Fit

\section{Linear Fit}

M2-LAl (Degrees) $=111.5427+0.3698309 * \mathrm{M} 2-\mathrm{D} 2$

Summary of Fit

$\begin{array}{lr}\text { RSquare } & 0.008374 \\ \text { RSquare Adj } & -0.02261 \\ \text { Root Mean Square Error } & 6.434031 \\ \text { Mean of Response } & 110.9412 \\ \text { Observations (or Sum Wgts) } & 34\end{array}$

\section{Analysis of Variance}

Sum of

$\begin{array}{lrrrr}\text { Source } & \text { DF } & \text { Squares } & \text { Mean Square } & \text { F Ratio } \\ \text { Model } & 1 & 11.1863 & 11.1863 & 0.2702 \\ \text { Error } & 32 & 1324.6961 & 41.3968 & \text { Prob > F } \\ \text { C. Total } & 33 & 1335.8824 & & 0.6068\end{array}$

\section{Parameter Estimates}

$\begin{array}{lrrrr}\text { Term } & \text { Estimate } & \text { Std Error } & \text { t Ratio } & \text { Prob }>|t| \\ \text { Intercept } & 111.5427 & 1.59892 & 69.76 & <.0001 \\ \text { M2-D2 } & 0.3698309 & 0.711448 & 0.52 & 0.6068\end{array}$




\section{Fit Group}

Bivariate Fit of M2 - LAl (Degrees) By $\mathrm{M} 2-\mathrm{D} 3$

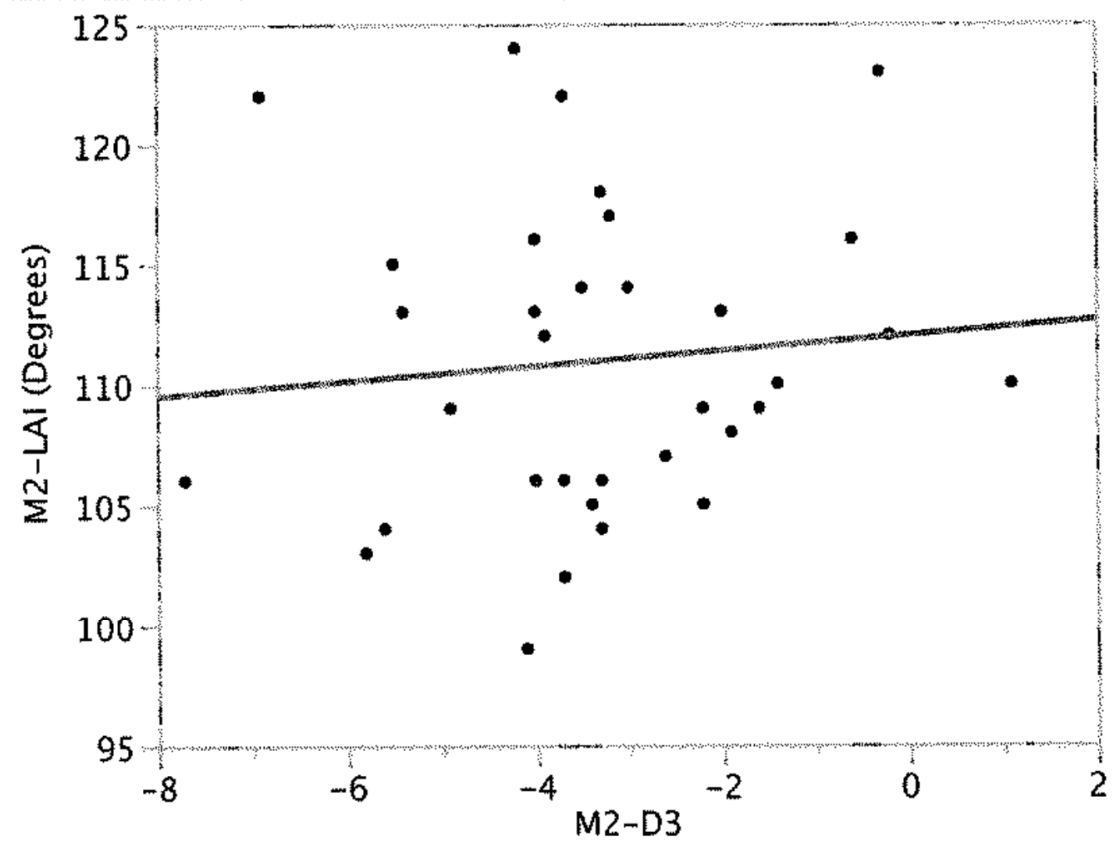

Linear Fit

Linear Fit

M2-LAl (Degrees) $=111.99125+0.3131803 * \mathrm{M} 2-\mathrm{D} 3$

Summary of Fit

RSquare

RSquare Adj

0.008649

Root Mean Square Error

$-0.02233$

Mean of Response

6.433136

Observations (or Sum Wgts)

110.9412

Analysis of Variance

$\begin{array}{lrrrr}\text { Source } & \text { DF } & \begin{array}{r}\text { Sum of } \\ \text { Squares }\end{array} & \text { Mean Square } & \text { F Ratio } \\ \text { Model } & 1 & 11.5545 & 11.5545 & 0.2792 \\ \text { Error } & 32 & 1324.3278 & 41.3852 & \text { Prob > F } \\ \text { C. Total } & 33 & 1335.8824 & & 0.6009\end{array}$

\section{Parameter Estimates}

Term Estimate Std Error $t$ Ratio Prob $>|t|$ Intercept $111.99125 \quad 2.273026 \quad 49.27 \quad 0.0001$

$\begin{array}{lllll}\text { M2-D3 } & 0.3131803 & 0.592709 & 0.53 & 0.6009\end{array}$ 


\section{Bivariate Fit of M2 - LAl (Degrees) By M2-DWALA}

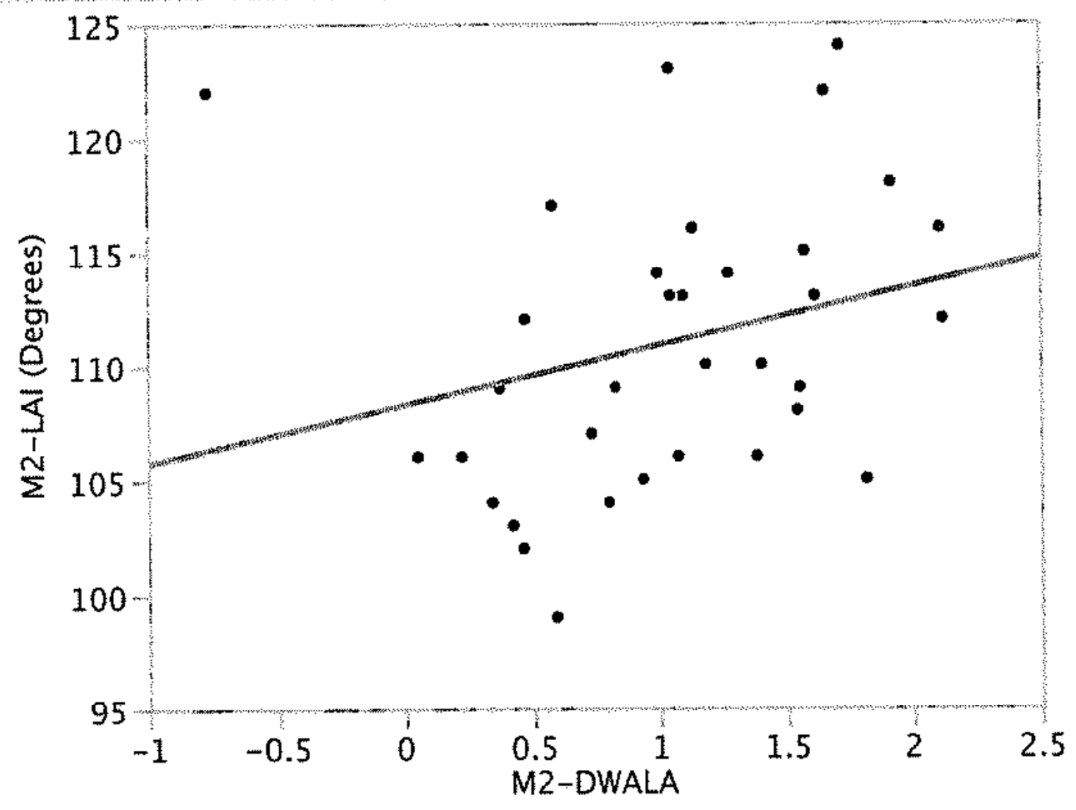

Linear Fit

\begin{tabular}{|c|c|c|c|c|}
\hline \multicolumn{5}{|l|}{ Linear Fit } \\
\hline \multicolumn{5}{|c|}{ M2-LAl (Degrees) $=108.26183+2.5741122 * \mathrm{M} 2-$ DWALA } \\
\hline \multicolumn{5}{|c|}{ Summary of Fit } \\
\hline $\begin{array}{l}\text { RSquare } \\
\text { RSquare } \\
\text { Root Me } \\
\text { Mean of } \\
\text { Observa }\end{array}$ & $\begin{array}{l}\text { Juare } \\
\text { onse } \\
\text { for: }\end{array}$ & Error & $\begin{array}{r}67233 \\
38084 \\
.24016 \\
0.9412 \\
34\end{array}$ & \\
\hline \multicolumn{5}{|c|}{ Analysis of Variance } \\
\hline $\begin{array}{l}\text { Source } \\
\text { Model }\end{array}$ & $\begin{array}{r}\text { DF } \\
1\end{array}$ & $\begin{array}{r}\text { Sum of } \\
\text { Squares } \\
89.8153\end{array}$ & $\begin{array}{r}\text { Mean Square } \\
89.8153\end{array}$ & $\begin{array}{l}\text { F Ratio } \\
2.3065\end{array}$ \\
\hline Error & 32 & 1246.0670 & 38.9396 & Prob $>F$ \\
\hline c. Total & 33 & 1335.8824 & & 0.1387 \\
\hline
\end{tabular}

\section{Parameter Estimates}

Term Estimate Std Error t Ratio Prob $>|\mathbf{t}|$

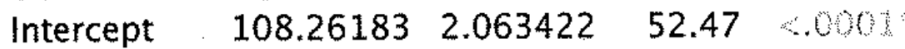

$\begin{array}{lllll}\text { M2-DWALA } & 2.5741122 & 1.694915 & 1.52 & 0.1387\end{array}$ 


\section{Bivariate Fit of P1-DWALA By P1-D1}

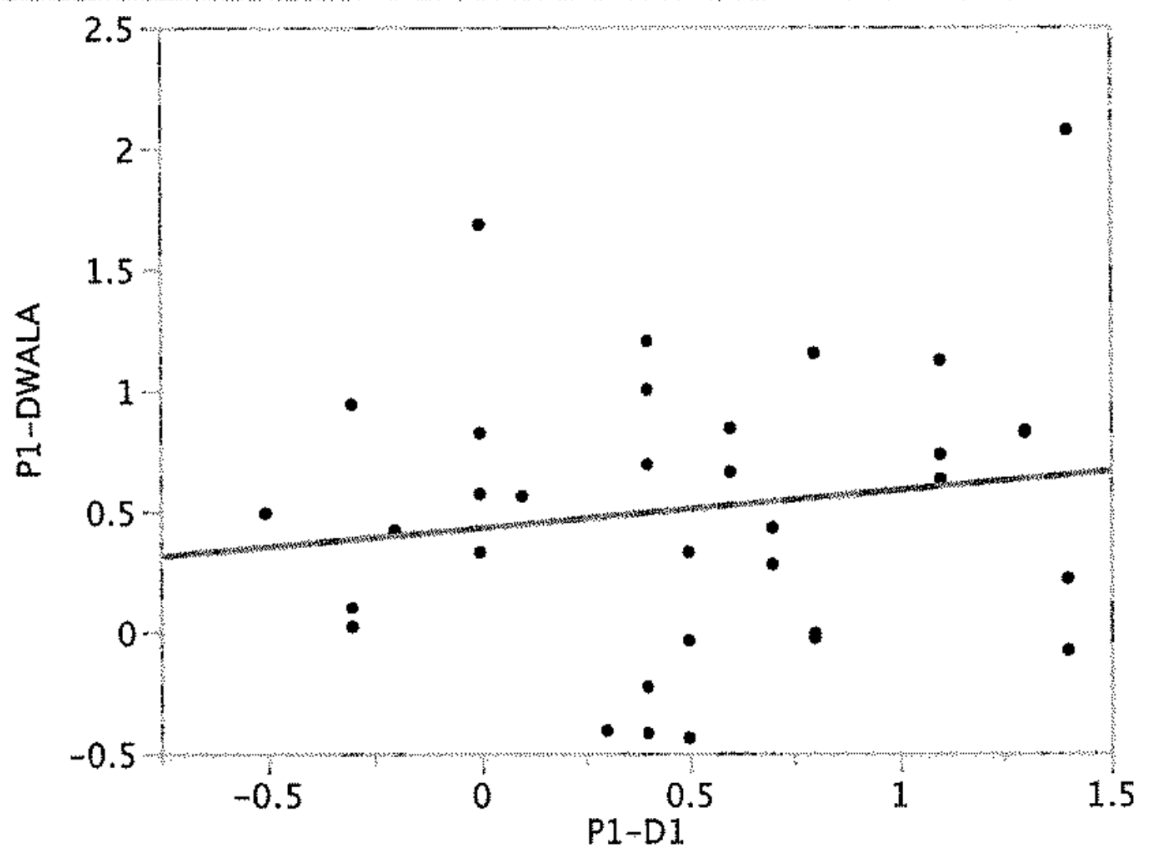

Linear Fit

\section{Linear Fit}

P1-DWALA $=0.4286462+0.1549443 * P 1-D 1$

\section{Summary of Fit}

$\begin{array}{lr}\text { RSquare } & 0.0214 \\ \text { RSquare Adj } & -0.00918 \\ \text { Root Mean Square Error } & 0.580294 \\ \text { Mean of Response } & 0.507941 \\ \text { Observations (or Sum Wgts) } & 34\end{array}$

Analysis of Variance

$\begin{array}{lrrrr}\text { Source } & \text { DF } & \begin{array}{r}\text { Sum of } \\ \text { Squares }\end{array} & \text { Mean Square } & \text { F Ratio } \\ \text { Model } & 1 & 0.235643 & 0.235643 & 0.6998 \\ \text { Error } & 32 & 10.775713 & 0.336741 & \text { Prob > F } \\ \text { C. Total } & 33 & 11.011356 & & 0.4091\end{array}$

\section{Parameter Estimates}

$\begin{array}{lrrrr}\text { Term } & \text { Estimate } & \text { Std Error } & \text { t Ratio } & \text { Prob }>|t| \\ \text { Intercept } & 0.4286462 & 0.137439 & 3.12 & 0.008 \\ \text { P1-D1 } & 0.1549443 & 0.185224 & 0.84 & 0.4091\end{array}$


Bivariate Fit of P1-DWALA By P1-D2

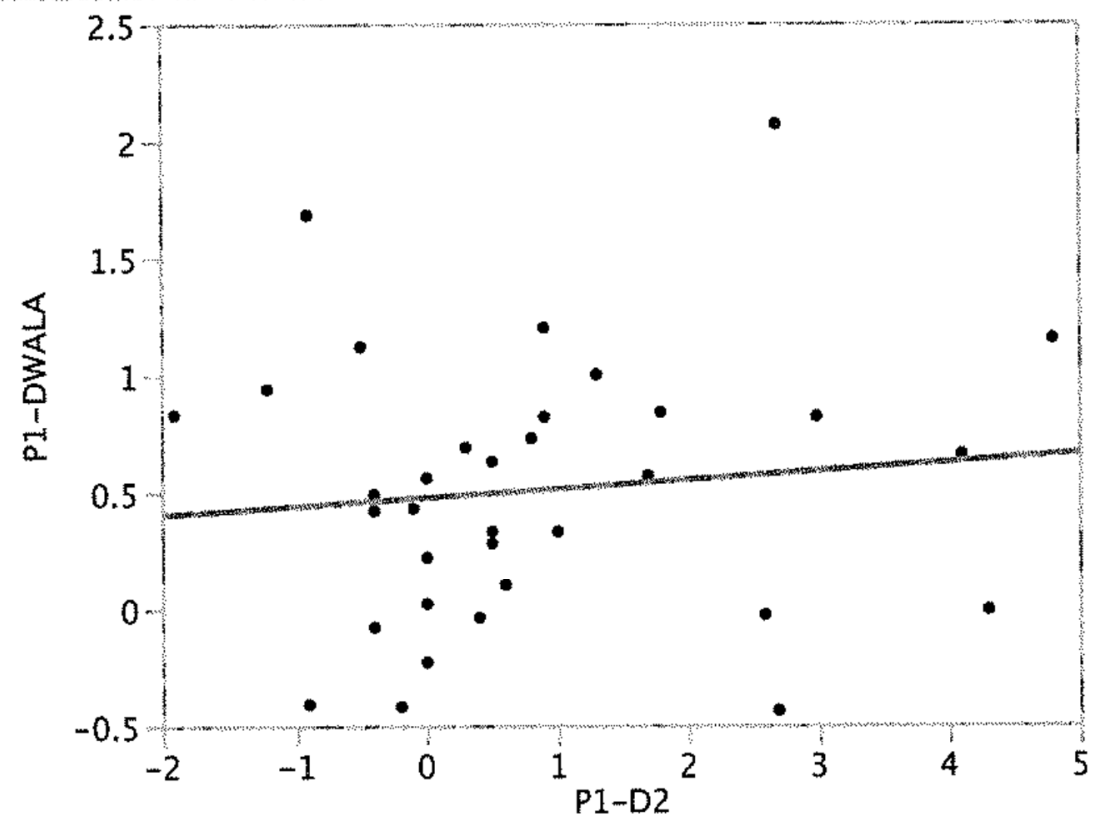

Linear Fit

Linear Fit

P1-DWALA $=0.4765156+0.0374901 *$ P1-D2

Summary of Fit

RSquare

0.010809

RSquare Adj

$-0.0201$

Root Mean Square Error

0.583426

Mean of Response

0.507941

Observations (or Sum Wgts)

34

\section{Analysis of Variance}

Sum of

Source DF Squares Mean Square F Ratio

$\begin{array}{lllll}\text { Model } & 1 & 0.119019 & 0.119019 & 0.3497\end{array}$

$\begin{array}{lllll}\text { Error } & 32 & 10.892337 & 0.340386 & \text { Prob > F }\end{array}$

C. Total

$33 \quad 11.011356$

0.5585

\section{Parameter Estimates}

Term Estimate Std Error t Ratio Prob $>|\mathbf{t}|$ $\begin{array}{lllll}\text { Intercept } & 0.4765156 & 0.113295 & 4.21 & 0.0002\end{array}$

$\begin{array}{lllll}\text { P1-D2 } & 0.0374901 & 0.063401 & 0.59 & 0.5585\end{array}$




\section{Fit Group}

Bivariate Fit of P1-DWALA By P1-D3

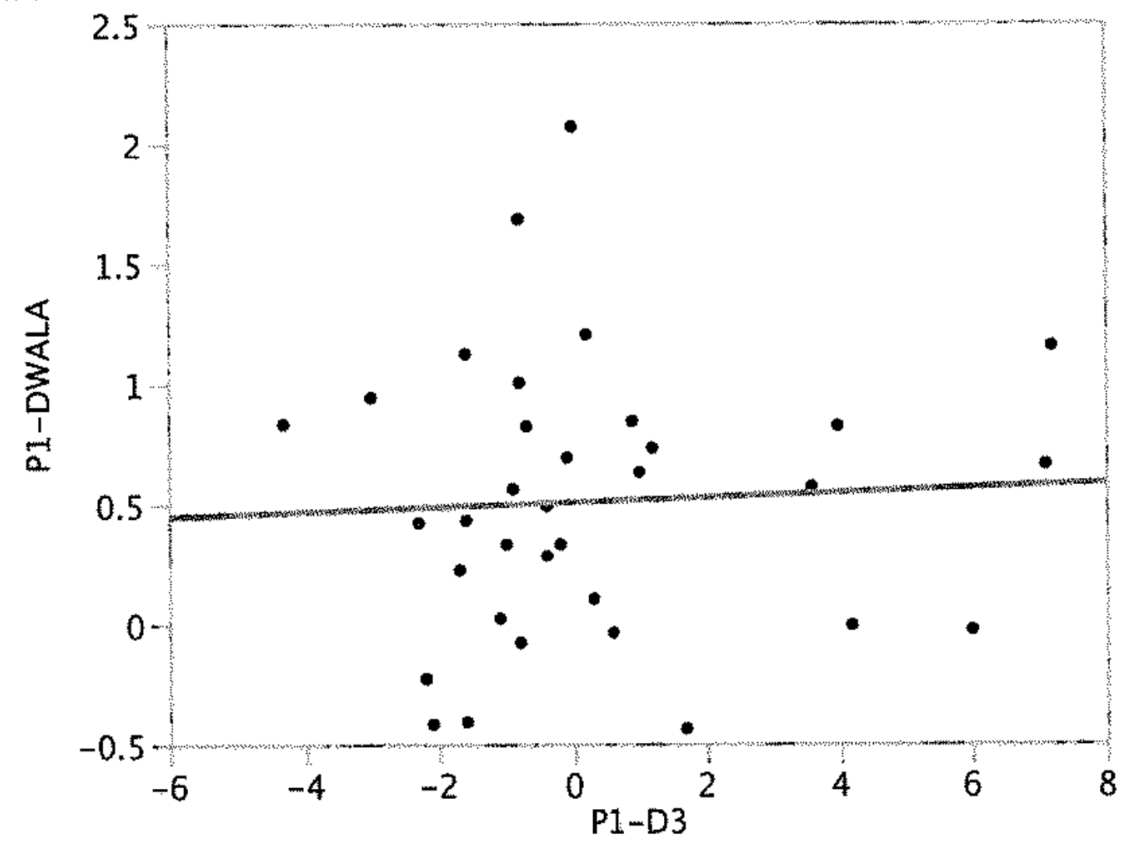

\begin{tabular}{|c|c|c|c|c|}
\hline \multicolumn{5}{|c|}{ Linear Fit } \\
\hline \multicolumn{5}{|l|}{ Linear Fit } \\
\hline \multicolumn{5}{|c|}{ P1-DWALA $=0.5049215+0.009872 * P 1-D 3$} \\
\hline \multicolumn{5}{|c|}{ Summary of Fit } \\
\hline $\begin{array}{l}\text { RSquare } \\
\text { RSquare } \\
\text { Root Mea } \\
\text { Mean of } \\
\text { Observat }\end{array}$ & $\begin{array}{l}\text { uare } \\
\text { ons } \\
\text { for }\end{array}$ & $\begin{array}{ll} & 0 . \\
\text { Error } & 0 . \\
& 0 .\end{array}$ & $\begin{array}{r}502183 \\
-0.029 \\
585964 \\
507941 \\
34\end{array}$ & \\
\hline \multicolumn{5}{|c|}{ Analysis of Variance } \\
\hline $\begin{array}{l}\text { Source } \\
\text { Model }\end{array}$ & $\begin{array}{r}\text { DF } \\
1\end{array}$ & $\begin{array}{r}\text { Sum of } \\
\text { Squares } \\
0.024042\end{array}$ & $\begin{array}{r}\text { Mean Square } \\
0.024042\end{array}$ & $\begin{array}{l}\text { F Ratio } \\
0.0700\end{array}$ \\
\hline $\begin{array}{l}\text { Error } \\
\text { C. Total }\end{array}$ & $\begin{array}{l}32 \\
33\end{array}$ & $\begin{array}{l}10.987313 \\
11.011356\end{array}$ & 0.343354 & $\begin{array}{c}\text { Prob > F } \\
0.7930\end{array}$ \\
\hline
\end{tabular}

\section{Parameter Estimates}

$\begin{array}{lrlrr}\text { Term } & \text { Estimate } & \text { Std Error } & \text { t Ratio } & \text { Prob }>|t| \\ \text { Intercept } & 0.5049215 & 0.101138 & 4.99 & 6.0001 \\ \text { P1-D3 } & 0.009872 & 0.037307 & 0.26 & 0.7930\end{array}$




\section{Bivariate Fit of P2-DWALA By P2-D1}

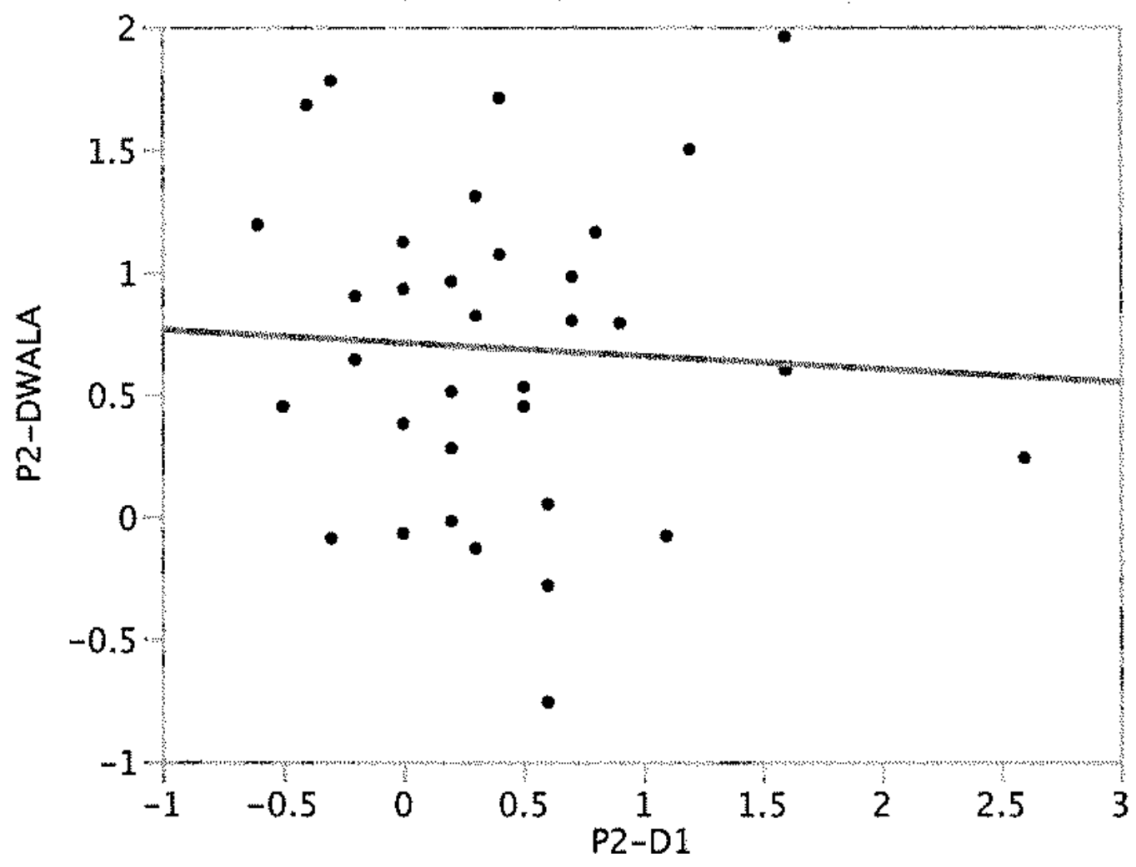

- Linear Fit

$\begin{array}{lr}\text { Linear Fit } & \\ \text { P2-DWALA }=0.70895 & -0.053 \\ \text { Summary of Fit } & \\ \text { RSquare } & 0.002935 \\ \text { RSquare Adj } & -0.02822 \\ \text { Root Mean Square Error } & 0.660903 \\ \text { Mean of Response } & 0.687059 \\ \text { Observations (or Sum Wgts) } & 34\end{array}$

Analysis of Variance

$\begin{array}{lrrrr}\text { Source } & \text { DF } & \begin{array}{r}\text { Sum of } \\ \text { Squares }\end{array} & \text { Mean Square } & \text { F Ratio } \\ \text { Model } & 1 & 0.041140 & 0.041140 & 0.0942 \\ \text { Error } & 32 & 13.977366 & 0.436793 & \text { Prob > F } \\ \text { C. Total } & 33 & 14.018506 & & 0.7609\end{array}$

Parameter Estimates

Term Estimate Std Error t Ratio Prob $>|\mathrm{t}|$

$\begin{array}{llllll}\text { Intercept } & 0.70895 & 0.133921 & 5.29 & 0.0001\end{array}$

$\begin{array}{lllll}\text { P2 } 2 \text { D1 } & -0.053164 & 0.173232 & -0.31 & 0.7609\end{array}$ 
Bivariate Fit of P2-DWALA By P2-D2

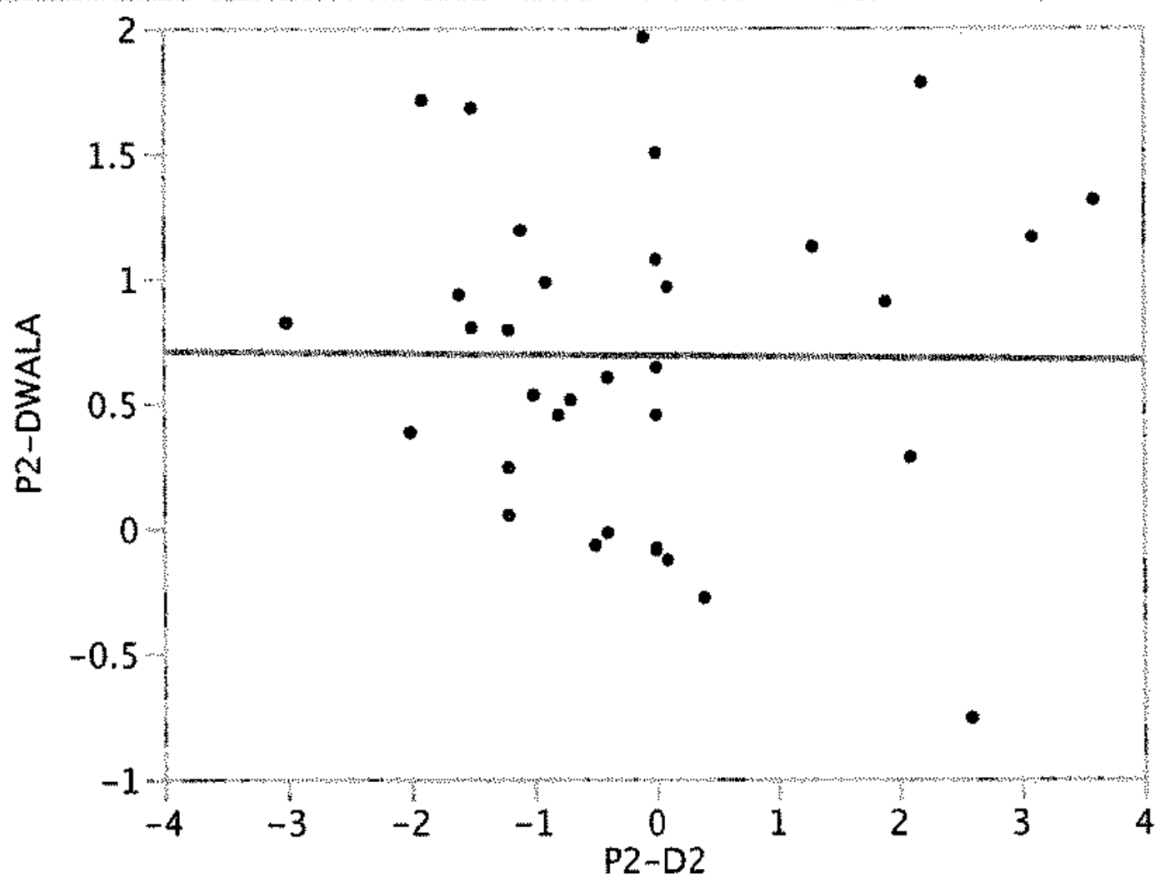

Linear Fit

\section{Linear Fit}

$P 2-D W A L A=0.6865688-0.0046282 * P 2-D 2$

Summary of Fit

$\begin{array}{lr}\text { RSquare } & 0.000117 \\ \text { RSquare Adj } & -0.03113 \\ \text { Root Mean Square Error } & 0.661836 \\ \text { Mean of Response } & 0.687059 \\ \text { Observations (or Sum Wgts) } & 34\end{array}$

Analysis of Variance

Sum of

$\begin{array}{lrrrr}\text { Source } & \text { DF } & \text { Squares } & \text { Mean Square } & \text { F Ratio } \\ \text { Model } & 1 & 0.001636 & 0.001636 & 0.0037 \\ \text { Error } & 32 & 14.016869 & 0.438027 & \text { Prob > F } \\ \text { C. Total } & 33 & 14.018506 & & 0.9516\end{array}$

\section{Parameter Estimates}

$\begin{array}{lrlrr}\text { Term } & \text { Estimate } & \text { Std Error } & \text { t Ratio } & \text { Prob }>|t| \\ \text { Intercept } & 0.6865688 & 0.113787 & 6.03 & -000 \\ \text { P2-D2 } & -0.004628 & 0.075719 & -0.06 & 0.9516\end{array}$




\section{Fit Group}

\section{Bivariate Fit of P2 - DWALA By P2 - D3}

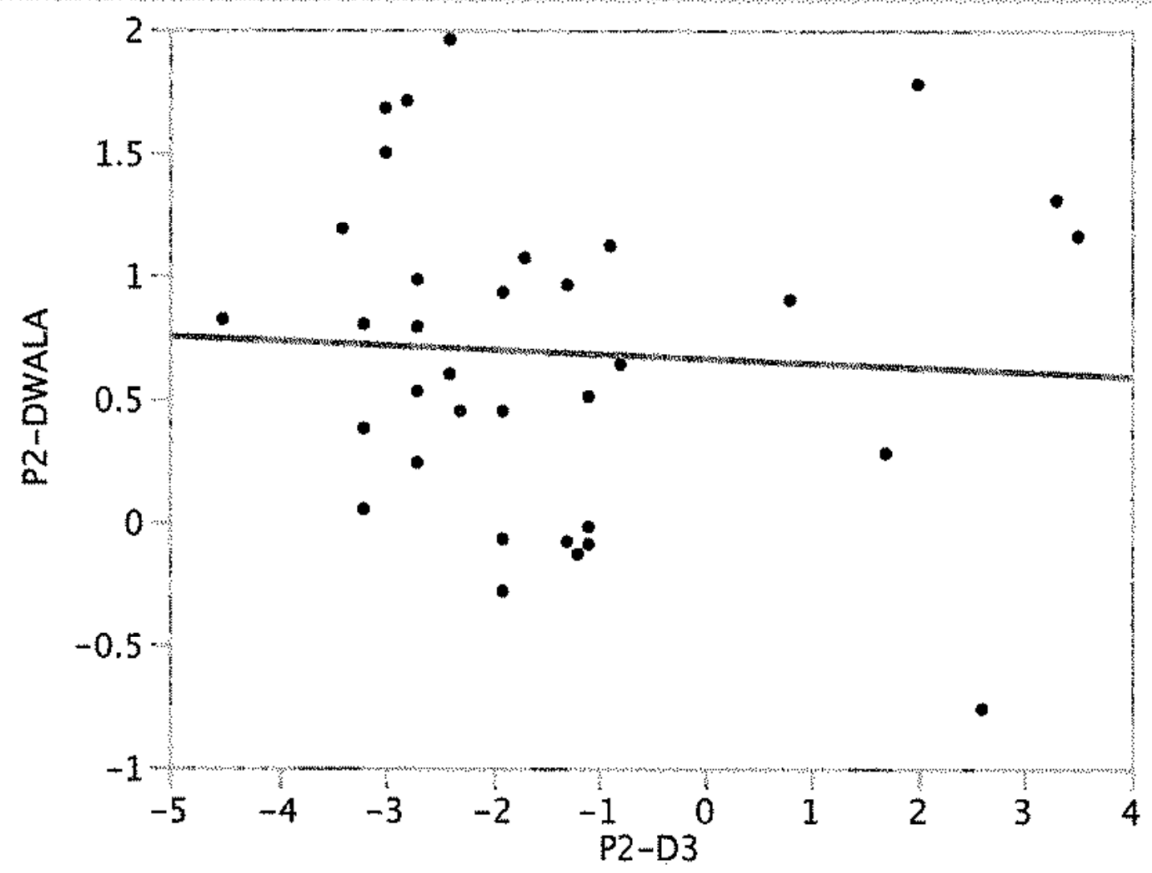

\begin{tabular}{lr}
\hline Linear Fit \\
P2-DWALA $=0.6614076-0.0180195 * P 2$ \\
Summary of Fit \\
RSquare \\
RSquare Adj & 0.003013 \\
Root Mean Square Error & -0.02814 \\
Mean of Response & 0.660877 \\
Observations (or Sum Wgts) & 0.687059 \\
\end{tabular}

\section{Analysis of Variance}

\section{Sum of}

$\begin{array}{lrrrr}\text { Source } & \text { DF } & \text { Squares } & \text { Mean Square } & \text { F Ratio } \\ \text { Model } & 1 & 0.042244 & 0.042244 & 0.0967 \\ \text { Error } & 32 & 13.976262 & 0.436758 & \text { Prob }>\text { F } \\ \text { C. Total } & 33 & 14.018506 & & 0.7578\end{array}$

\section{Parameter Estimates}

$\begin{array}{lrrrc}\text { Term } & \text { Estimate } & \text { Std Error } & \text { t Ratio } & \text { Prob }>|t| \\ \text { Intercept } & 0.6614076 & 0.140174 & 4.72 & .0001 \\ \text { P2-D3 } & -0.018019 & 0.05794 & -0.31 & 0.7578\end{array}$




\section{Bivariate Fit of M1-DWALA By M 1-D1}

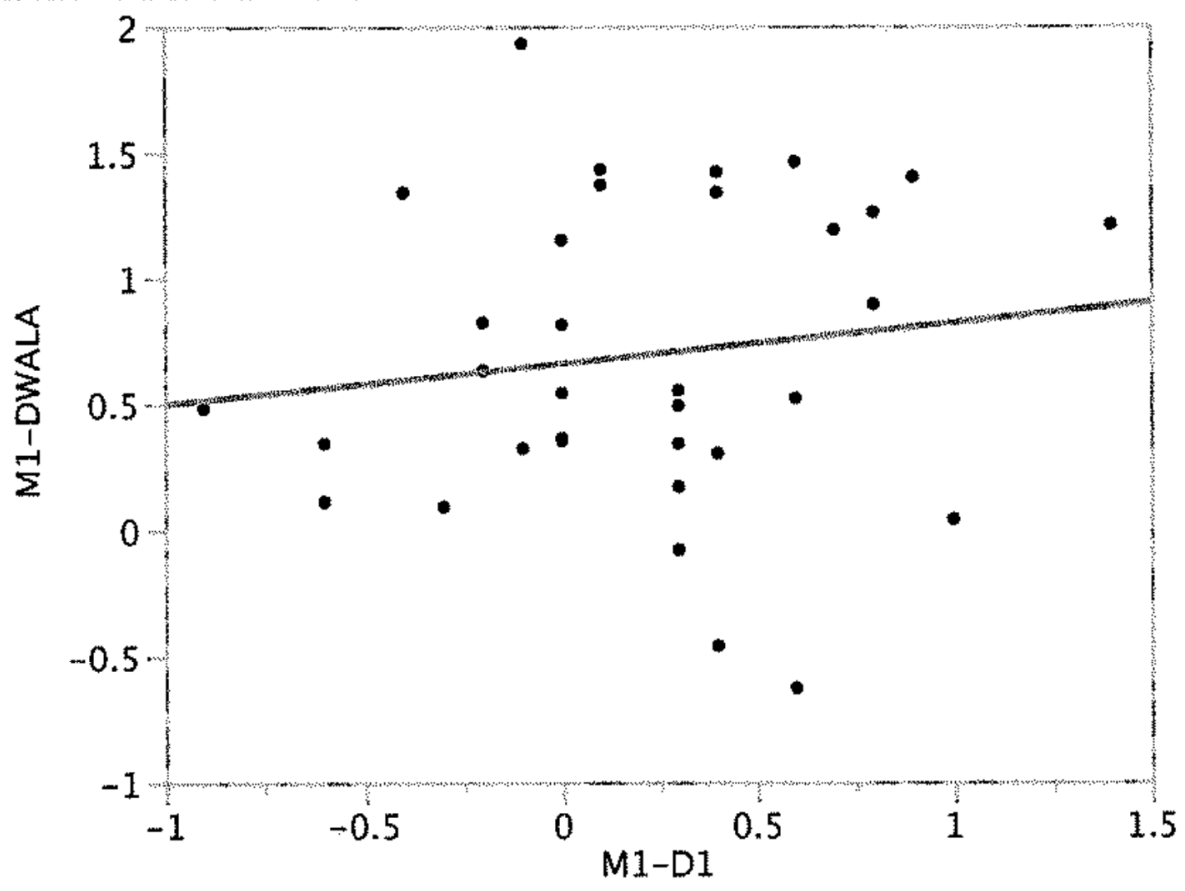

Linear Fit

\section{Linear Fit}

M1-DWALA $=0.6559715+0.1612287^{*} \mathrm{M} 1-\mathrm{D} 1$

Summary of Fit

RSquare

RSquare Adj

Root Mean Square Error

Mean of Response

Observations (or Sum Wgts)
0.017257

$-0.01345$

0.609967

0.690588

\section{Analysis of Variance}

$\begin{array}{lrrrr}\text { Source } & \text { DF } & \begin{array}{r}\text { Sum of } \\ \text { Squares }\end{array} & \text { Mean Square } & \text { F Ratio } \\ \text { Model } & 1 & 0.209066 & 0.209066 & 0.5619 \\ \text { Error } & 32 & 11.905922 & 0.372060 & \text { Prob }>\text { F } \\ \text { C. Total } & 33 & 12.114988 & & 0.4590\end{array}$

\section{Parameter Estimates}

$\begin{array}{lrlrr}\text { Term } & \text { Estimate } & \text { Std Error } & \text { t Ratio } & \text { Prob }>|\mathbf{t}| \\ \text { Intercept } & 0.6559715 & 0.114348 & 5.74 & 4.0001 \\ \text { M1-D1 } & 0.1612287 & 0.215083 & 0.75 & 0.4590\end{array}$




\section{Bivariate Fit of M1-DWALA By M1-D2}

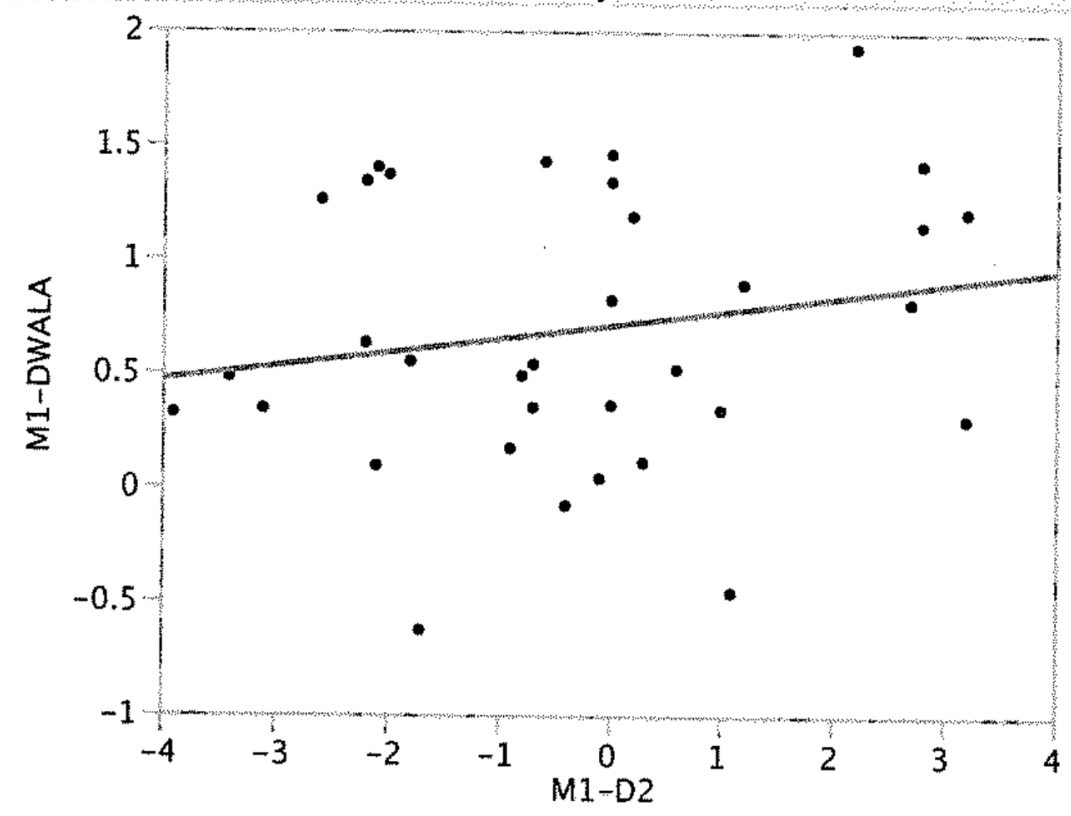

Linear Fit

Linear Fit

M1-DWALA $=0.7083981+0.0605535 * \mathrm{M} 1-\mathrm{D} 2$

Summary of Fit

$\begin{array}{lr}\text { RSquare } & 0.037596 \\ \text { RSquare Adj } & 0.007521 \\ \text { Root Mean Square Error } & 0.603622 \\ \text { Mean of Response } & 0.690588 \\ \text { Observations (or Sum Wgts) } & 34\end{array}$

Analysis of Variance

$\begin{array}{lrrrr}\text { Source } & \text { DF } & \begin{array}{r}\text { Sum of } \\ \text { Squares }\end{array} & \text { Mean Square } & \text { F Ratio } \\ \text { Model } & 1 & 0.455476 & 0.455476 & 1.2501 \\ \text { Error } & 32 & 11.659512 & 0.364360 & \text { Prob > F } \\ \text { C. Total } & 33 & 12.114988 & & 0.2719\end{array}$

Parameter Estimates

$\begin{array}{lrrrr}\text { Term } & \text { Estimate } & \text { Std Error } & \text { t Ratio } & \text { Prob }>|\mathbf{t}| \\ \text { Intercept } & 0.7083981 & 0.104739 & 6.76 & 0001 \\ \text { M1-D2 } & 0.0605535 & 0.054159 & 1.12 & 0.2719\end{array}$




\section{Fit Group}

Bivariate Fit of M1 -DWALA By M1 D3

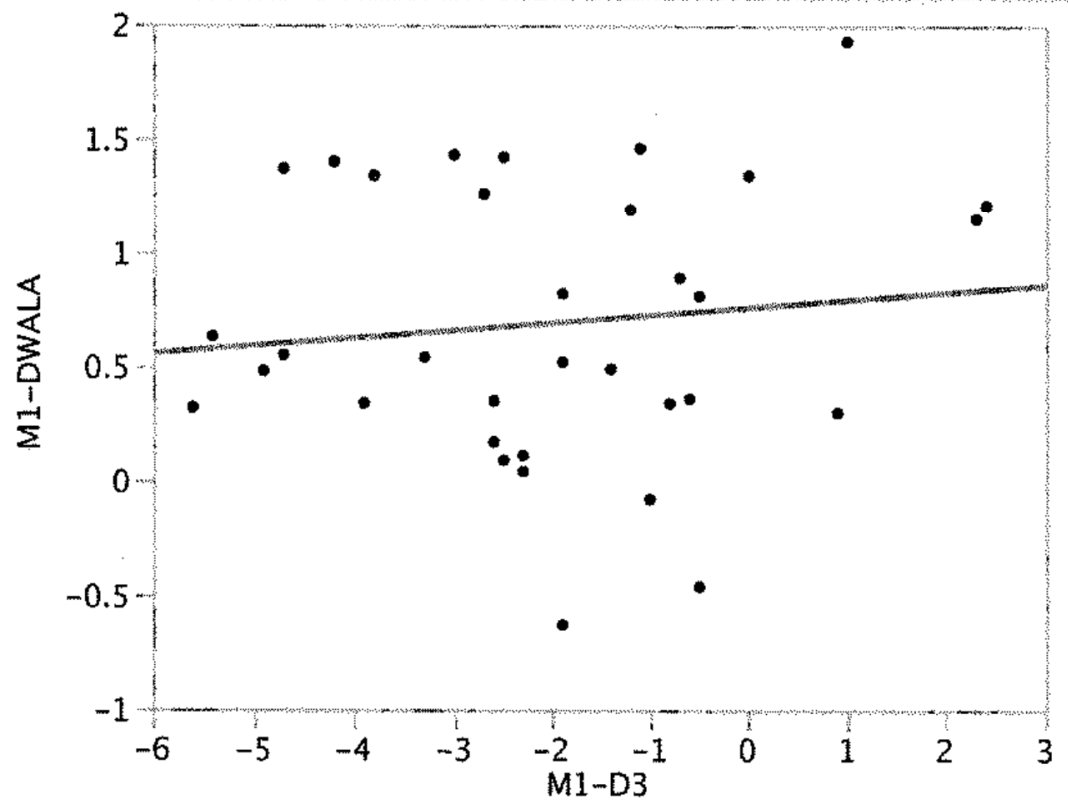

Linear Fit

Linear Fit

M1-DWALA $=0.757677+0.0335938 * M 1-D 3$

Summary of Fit

$\begin{array}{lr}\text { RSquare } & 0.012619 \\ \text { RSquare Adj } & -0.01824 \\ \text { Root Mean Square Error } & 0.611405 \\ \text { Mean of Response } & 0.690588 \\ \text { Observations (or Sum Wgts) } & 34\end{array}$

Analysis of Variance

Sum of

$\begin{array}{lrrrr}\text { Source } & \text { DF } & \text { Squares } & \text { Mean Square } & \text { F Ratio } \\ \text { Model } & 1 & 0.152883 & 0.152883 & 0.4090 \\ \text { Error } & 32 & 11.962105 & 0.373816 & \text { Prob > F } \\ \text { C. Total } & 33 & 12.114988 & & 0.5270\end{array}$

Parameter Estimates

Term Estimate Std Error t Ratio Prob $>|\mathbf{t}|$

$\begin{array}{lllll}\text { Intercept } & 0.757677 & 0.148323 & 5.11 & \times .00 \% l^{2}\end{array}$

$\begin{array}{lllll}\text { M1-D3 } & 0.0335938 & 0.05253 & 0.64 & 0.5270\end{array}$ 


\section{Bivariate Fit of M2-DWALA By M2-D1}

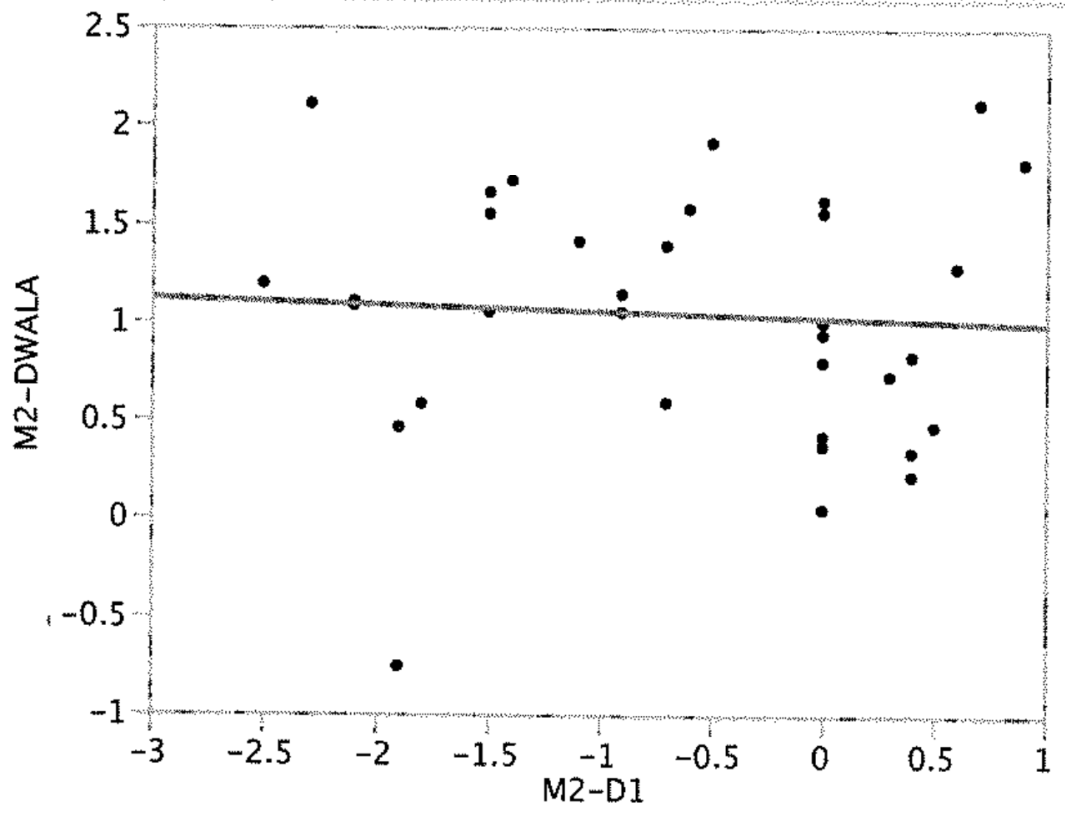

Linear Fit

\section{Linear Fit}

M2-DWALA $=1.0211585-0.0309037 * \mathrm{M} 2-D 1$

\section{Summary of Fit}

$\begin{array}{lr}\text { RSquare } & 0.002296 \\ \text { RSquare Adj } & -0.02888 \\ \text { Root Mean Square Error } & 0.65009 \\ \text { Mean of Response } & 1.040882 \\ \text { Observations (or Sum Wgts) } & 34\end{array}$

Analysis of Variance

$\begin{array}{lrrrr}\text { Source } & \text { DF } & \begin{array}{r}\text { Sum of } \\ \text { Squares }\end{array} & \text { Mean Square } & \text { F Ratio } \\ \text { Model } & 1 & 0.031116 & 0.031116 & 0.0736 \\ \text { Error } & 32 & 13.523758 & 0.422617 & \text { Prob > F } \\ \text { C. Total } & 33 & 13.554874 & & 0.7879\end{array}$

\section{Parameter Estimates}

$\begin{array}{lrrrr}\text { Term } & \text { Estimate } & \text { Std Error } & \mathbf{t} \text { Ratio } & \text { Prob }>|\mathbf{t}| \\ \text { Intercept } & 1.0211585 & 0.133093 & 7.67 & <.0001 \\ \text { M2-D1 } & -0.030904 & 0.113893 & -0.27 & 0.7879\end{array}$


Bivariate Fit of M2-DWALA By M2-D2

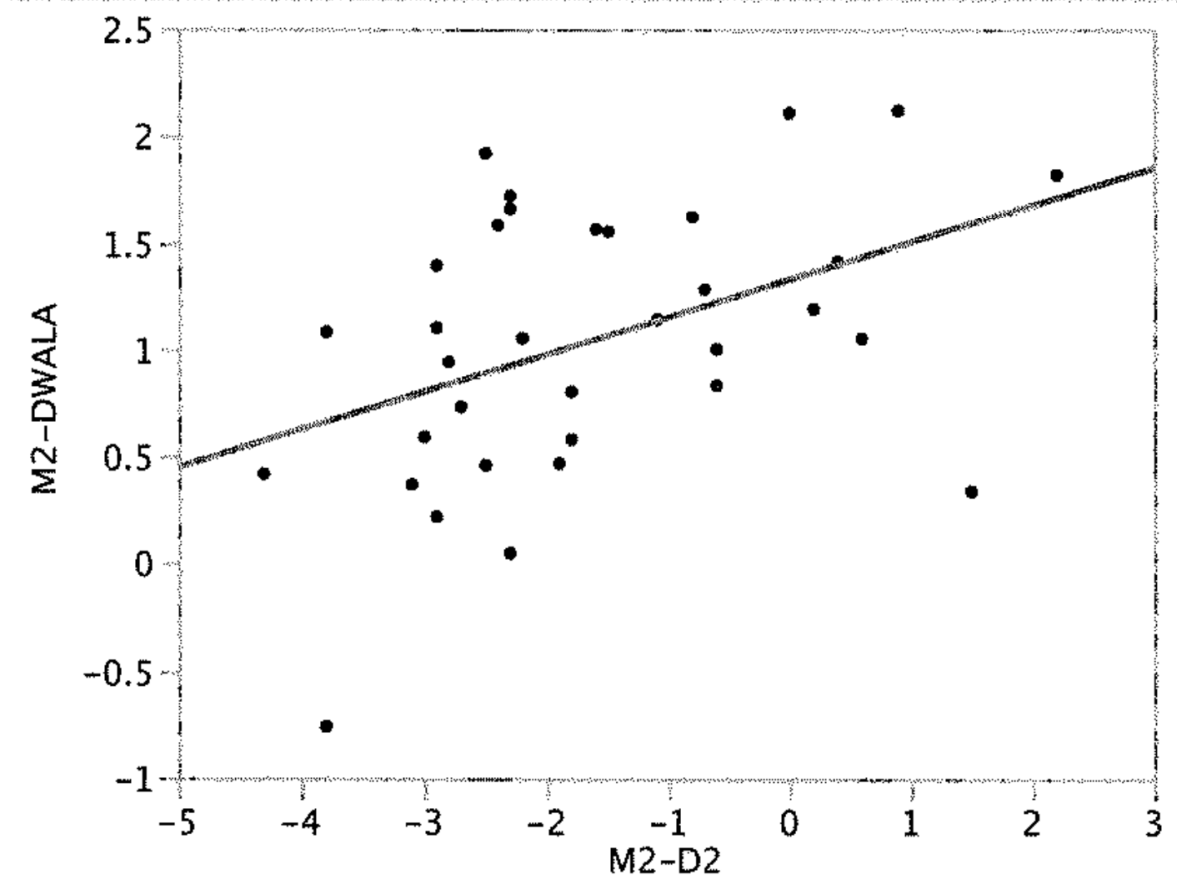

Linear Fit

\section{Linear Fit}

M2-DWALA $=1.3258769+0.1752227^{*}$ M2-D2

Summary of Fit

\begin{tabular}{|c|c|c|c|c|}
\hline \multicolumn{5}{|c|}{0.185253} \\
\hline \multicolumn{3}{|c|}{ RSquare Adj } & .159792 & \\
\hline \multicolumn{3}{|c|}{ Root Mean Square Error } & .587468 & \\
\hline \multicolumn{3}{|c|}{ Mean of Response } & 1.040882 & \\
\hline \multicolumn{3}{|c|}{ Observations (or Sum Wgts) } & 34 & \\
\hline \multicolumn{5}{|c|}{ Analysís of Variance } \\
\hline Source & DF & $\begin{array}{l}\text { Sum of } \\
\text { Squares }\end{array}$ & S Mean Square & F Ratio \\
\hline Model & 1 & 2.511080 & 2.51108 & 7.2760 \\
\hline Error & 32 & 11.043793 & 0.34512 & Prob $>F$ \\
\hline C. Total & 33 & 13.554874 & & $0.0111^{*}$ \\
\hline
\end{tabular}

\section{Parameter Estimates}

Term Estimate Std Error t Ratio Prob $>|\mathbf{t}|$

$\begin{array}{llllll}\text { Intercept } & 1.3258769 & 0.145992 & 9.08 & <0001\end{array}$

$\begin{array}{lllll}\text { M2-D2 } & 0.1752227 & 0.06496 & 2.70 & 0.0111 *\end{array}$ 


\section{Fit Group}

Bivariate Fit of M2-DWALA By M2-D3

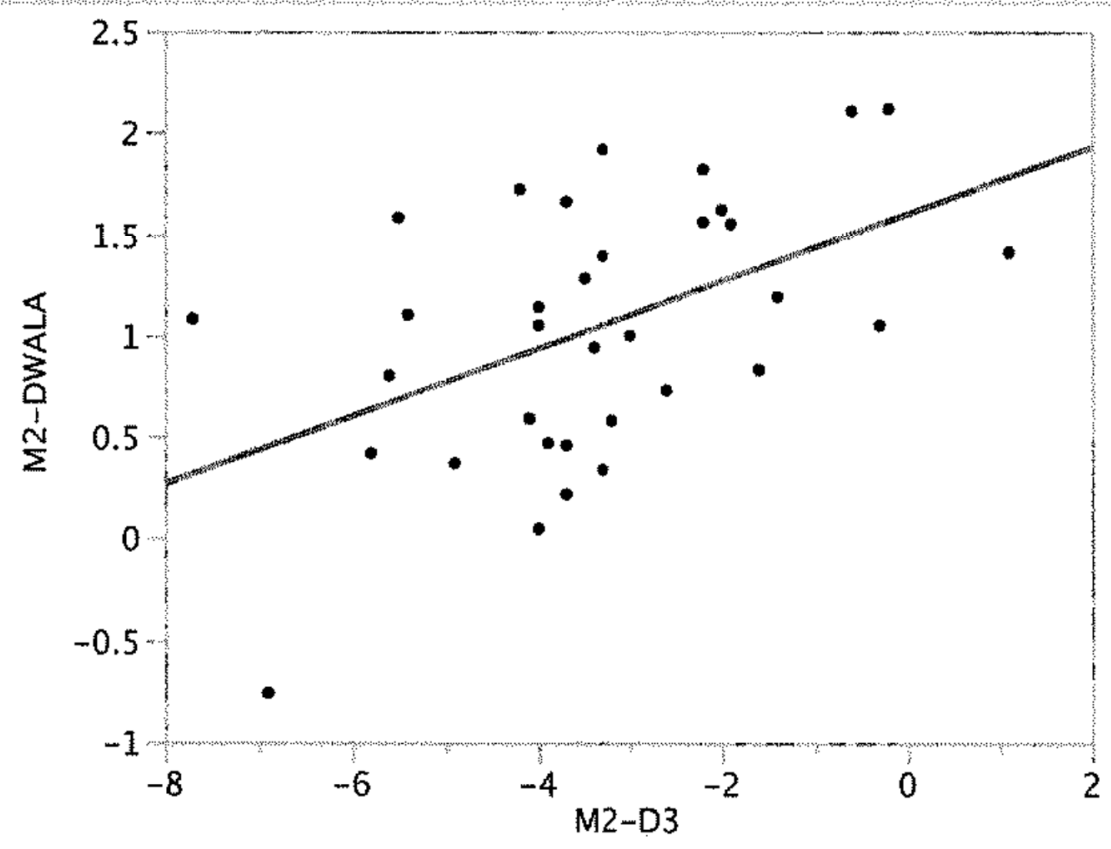

\begin{tabular}{|c|c|c|c|c|}
\hline - Linea & & & & \\
\hline Linear Fi & & & & \\
\hline M2-DWALA & .598 & $954+0.16$ & $63057 * \mathrm{M} 2-\mathrm{D} 3$ & \\
\hline Summa & of $\mathrm{Fi}$ & & & \\
\hline $\begin{array}{l}\text { RSquare } \\
\text { RSquare } \\
\text { Root Mea } \\
\text { Mean of } \\
\text { Observat }\end{array}$ & $\begin{array}{l}\text { quare } \\
\text { ponse } \\
\text { (or }\end{array}$ & Error & $\begin{array}{r}.240371 \\
.216632 \\
.567249 \\
1.040882 \\
34\end{array}$ & \\
\hline Analysi & f Va & lance & & \\
\hline $\begin{array}{l}\text { Source } \\
\text { Model }\end{array}$ & $\begin{array}{r}\text { DF } \\
1\end{array}$ & $\begin{array}{r}\text { Sum o } \\
\text { Squares } \\
3.258192\end{array}$ & Mean Square & $\begin{array}{r}\text { F Ratio } \\
10.1258\end{array}$ \\
\hline Error & 32 & 10.29668 & 0.32177 & Prob $>F$ \\
\hline C. Total & 33 & 13.55487 & & 0.0032 \\
\hline
\end{tabular}

\section{Parameter Estimates}

Term Estimate Std Error $\mathbf{t}$ Ratio Prob $>|\mathbf{t}|$ $\begin{array}{lllllll}\text { Intercept } & 1.5984954 & 0.200427 & 7.98 & <.0001\end{array}$

$\begin{array}{lllll}M 2-D 3 & 0.1663057 & 0.052263 & 3.18 & 0.0032\end{array}$

